NATURAL GAS ACCUMULATIONS IN LOW-PERMEABILITY TERTIARY, AND CRETACEOUS (CAMPANIAN AND MAASTRICHTIAN) ROCK, UINTA BASIN, UTAH

Final Report

By

T. D. Fouch

C. J. Wandrey

J. K. PItman

V. F. Nuccio

J. W. Schmoker

D. D. Rice

R. C. Johnson

G. L. Dolton

February 1992

Work Performed Under Contract No. Al21-83MC20422

For

U.S. Department of Energy

Morgantown Energy Technoiogy Center

Morgantown, West Virginla

By

U.S. Department of Interlor

U.S. Geological Survey

Lakewood, Colorado 


\section{DISCLAIMER}

This report was prepared as an account of work sponsored by an agency of the United States Government. Neither the United States Government nor any agency thereof, nor any of their employees, makes any warranty, express or implied, or assumes any legal liability or responsibility for the accuracy, completeness, or usefulness of any information, apparatus, product, or process disclosed, or represents that its use would not infringe privately owned rights. Reference herein to any specific commercial product, process, or service by trade name, trademark, manufacturer, or otherwise does not necessarily constitute or impiy its endorsement, recommendation, or favoring by the United States Government or any agency thereof. The views and opinions of authors expressed herein do not necessarily state or reflect those of the United States Government or any agency thereof.

This report has been reproduced directly from the best available copy.

Available to DOE and DOE contractors from the Office of Scientific and Technical Information, P.O. Box 62, Oak Ridge, TN 37831; prices available from (615)576-8401, FTS 626-8401.

Available to the public from the National Technical Information Service, U.S. Department of Commerce, 5285 Port Royal Rd., Springfield, VA 22161. 


\title{
Natural Gas Accumulations in Low-Permeability Tertiary, and Cretaceous (Campanian and Maastrichtian) Rock, Uinta Basin, Utah
}

Final Report

\author{
T.D. Fouch \\ C.J. Wandrey \\ J.K. Pitman \\ V.F. Nuccio \\ J.W. Schmoker \\ D.D. Rice \\ R.C. Johnson \\ G.L. Dolton
}

Work Performed Under Interagency Agreement No.: DE-AI21-83MC20422

For

U.S. Department of Energy

Office of Fossil Energy

Morgantown Energy Technology Center

P.O. Box 880

Morgantown, West Virginia 26507-0880

By

U.S. Department of Interior

U.S. Geological Survey

P.O. Box 25046

Lakewood, Colorado 80225-0046

February 1992 


\section{TABLE OF CONTENTS}

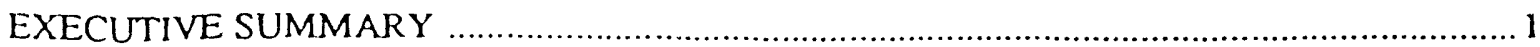

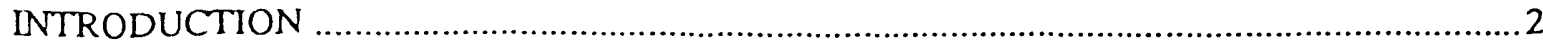

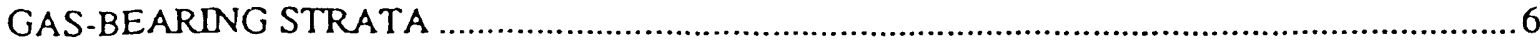

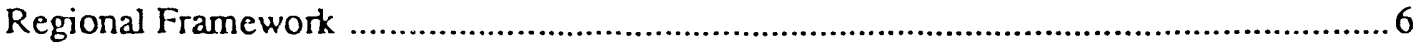

Campanian and Maastrichtian Cretaceous Rocks .............................................. 10

Paleocene and Eocene Rocks ....................................................................... 10

Lithologic and Depositional Character of Productive Sequences .................................... 19

Red Wash, Altamont-Bluebell, and Pariette Bench Producing Areas ................... 19

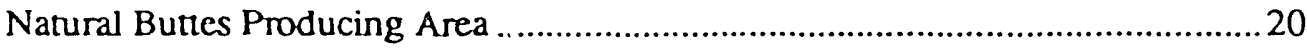

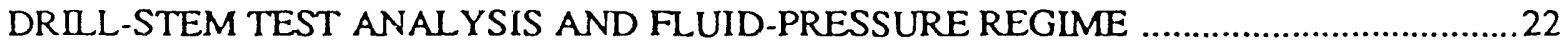

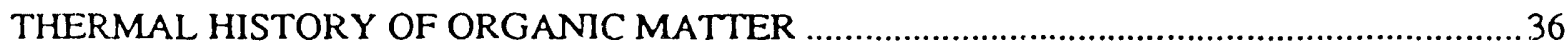

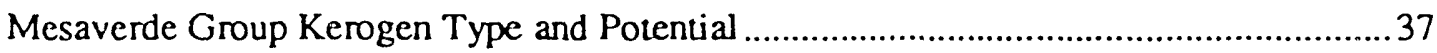

$\mathrm{R}_{\mathrm{m}}$ Map at Base of the Mesaverde Group. .....................................................44

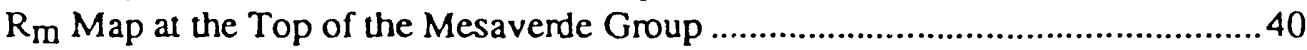

Map Showing Elevation to 0.75 percent $\mathrm{Rm}$....................................................42

Cross-section Showing Rm Lines and Kerogen Type Through the Uinta Basin .. 44

$R_{m}$ and Fluid-Pressure Gradients ..................................................................44

$R_{m}$ and Estimates of Removed Overburden .................................................44

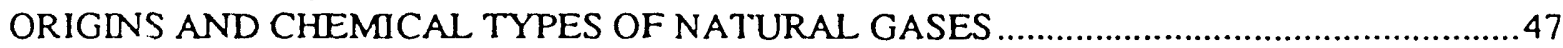

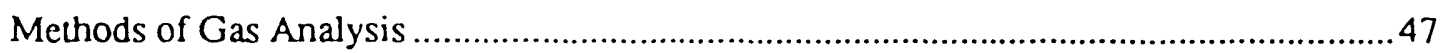

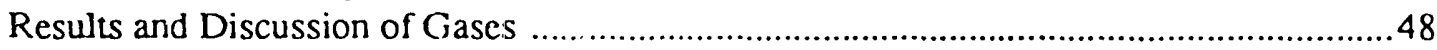

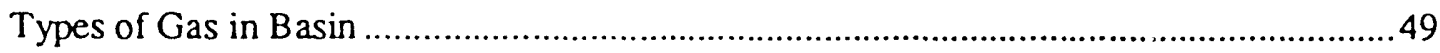

Natural Butes Field Gas ..............................................................................5 51

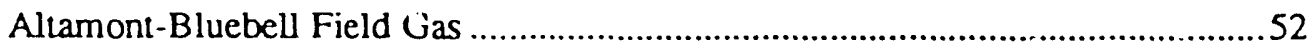

Red Wash Field Gas ........................................................................................5

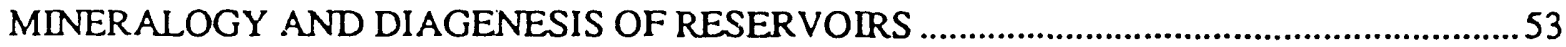

Sandstone Composition and Reservoir Quality ..........................................................5

Detrital Constituents in Cretaceous and Tertiary Rock .......................................5

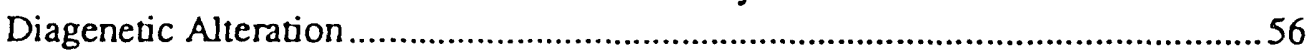

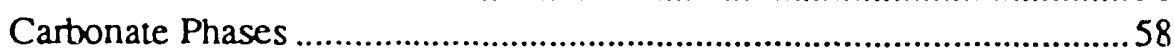

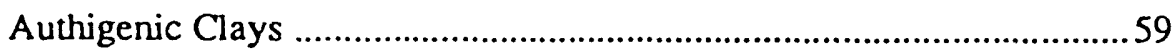

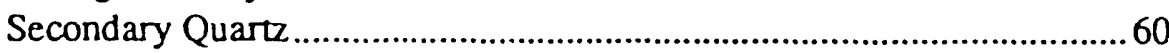

Other Diagenetic Phases ..........................................................................6 60

Petrophysical Properties of Sandstone Bodies ...................................................60 60

Regional Trends in Reservoir Quality ............................................................6 60

Mineralogy and Diagensis of Ked Wash Reservoirs ...........................61

Mineralogy and Diagensis of Altamont-Bluebell Reservoirs ..................62

Mineralogy and Diagenesis of Natural Buttes Reservoirs .......................62

Mineralogy and Diagenesis of Pariette Bench Reservoirs ......................64

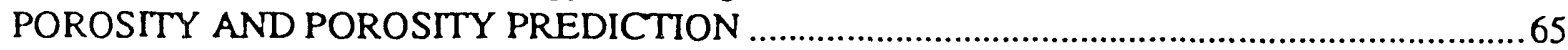

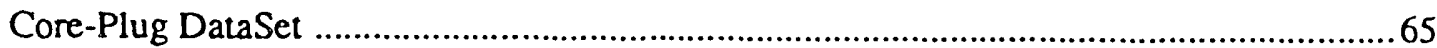

Typical Porosities of Nonmarine Mesaverde Sandstones ...............................................66

Influence Upon Porosity of Cretaceous-Tertiary Unconformity ......................................69

Above Average Porosities of Nonmarine Mesaverde Sandstones ....................................69

Comparison of Porosities-Mesaverde Group and Wasatch-Green River Formations .....69

Predicting Porosity for the Mesaveme Group Using Maturity-Porosity Trends .................70

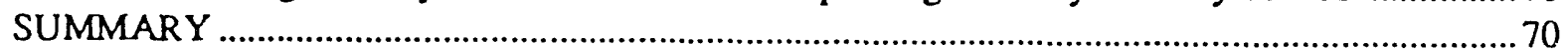

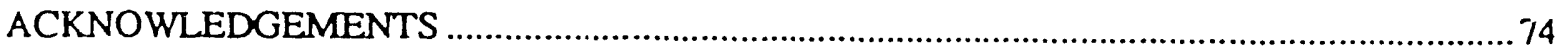

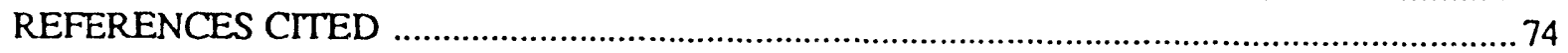




\title{
NATURAL GAS ACCUMULATIONS IN LOW-PERMEABILITY TERTIARY AND CRETACEOUS (CAMPANIAN AND MAASTRICHTIAN) ROCK, UINTA BASIN, UTAH
}

\author{
by
}

\author{
Thomas D. Fouch, Craig J. Wandrey, Janet K. Pitman, Vito F. Nuccio, \\ James W. Schmoker, Dudley D. Rice, Ronald C. Johnson, and Gordon L. Dolton \\ U.S. Geological Survey, Lakewood, CO
}

\section{EXECUTIVE SUMMARY}

Most known accumulations of nonassociated gas in the Uinta Basin occur east of the Green River where they are developed within rocks of the Campanian and Maastrichtian Mesaverde Group, Maastrichtian to lower Eocene North Hom Formation, and the Paleocene and Eocene Wasatch, Colton, and Green RiverFormations. Most gas is produced from fields developed near the surface trace of subsurface faults and fractures. The productive oil and gas-bearing rocks can be divided into three groups of common reservoir character. Group I is composed of oil - and associated gas-bearing deeply buried overpressured Tertiary rocks that are characterized by reservoirs whose in situ matrix permeability values are near, and are commonly below, $0.1 \mathrm{md}$ and whose porosity values (most porosity being secondary) average 5 percent, ranging from 3 to 10 percent. These strata contain open fractures and transmissivity $(T=$ permeability $x$ height $)$ values through producing intervals that are commonly high. Group II rocks are characterized by combined primary and secondary porosity values of 10 to 16 percent in normally pressured Tertiary oil and associated gas reservoirs whose matrix permeability values may be as high as $1 \mathrm{~d}$. Transmissivity values for such sequences can be relatively high because of their high matrix permeability. Group III rocks include nonassociated gas Tertiary and Cretaceous sandstone reservoirs that commonly contain porosity values ranging from 8 to 16 percent, but whose in situ permeability throughout the pay or gas producing section is $0.1 \mathrm{md}$ or less to gas (exclusive of fracture permeability). They are classified as tight gas sandstones. Transmissivity values for productive "tight gas" intervals are very low because of relatively few natural open fractures.

Channel-form sandstone units are the principal reservoirs for both oil and gas in the Uinta Basin. Tertiary channel sandstones on surface exposures of the basin's south flank can be separated into two distinct types with respect to geometry and widthy depth (W/D) ratio. Type I is characterized by a tabular geometry controlled by a planar lower bounding surface, an average channel depth of $7.6 \mathrm{~m}$, and an average $\mathrm{W} / \mathrm{D}$ ratio of 8.9 . Type II bodies are characterized by a lenticular geometry, by an average channel depth of $5.7 \mathrm{~m}$, an average $W / D$ ratio of 3.6 , and a concaveupward lower bounding surface. The size of individual channel sandstone bodies (and therefore reservoirunits) is largely dependent upon induration of the substrate across which streams flowed.

Some structural discontinuities that cut the Cretaceous and Tertiary units of the basin represent reactivation of covered structures associated with the ancestral Uncomphagre structural element. Some nonassociated gas has migrated from Cretaceous source rocks through a permeable network of faults and fractures in Cretaceous and Tertiary strata to the slightly overpressured and normally pressured reservoirs of the Mesaverde Group and Wasatch Formation in the eastern and southem parts of the basin. Although permeability values are low for many sequences, natural fractures evidently provide major conduits to move fluids and gases to the wellbore in otherwise relatively lowpermeability strata. An evident lack of significant natural open fracture systems in impermeable strata of the southeastem part of the Uinta Basin (area of tightgas production) has resulted in very low producibility except for those isolated zones composed of porous sandstones.

Projection of maturity values and fluid-pressure data to undrilled parts of the basin, and the current subsurface temperatures indicate the probability of regional, overpressured, basin-centered gas accumulation in Cretaceous rocks, where gas generation is likely to be occurring at present.

Based on chemical and isotopic composition, two classes (types) of thermogenic gases have been identi- 
fied in the Uinta Basin. Class A is nonassociated, chemically dry, and isotopically heavy. This gas is interpreted to have been gerierated from oxygen-rich kerogen primarily in the Mesaverde Group at high levels of thermal maturity (late catagenesis-metagenesis). This gas occurs in both Mesaverde and Wasatch reservoirs over a wide depth range in the greater Natural Buttes field area.

Class B gas is chemically wet and isotopically light, and it is associated with oil. Class B gas was generated during time of major oil generation (catagenesis) and from hydrogen-rich kerogen typical of Green River Formation open-lacustrine facies. Thermogenic hydrocarbons were generated in the deep part of the basin to the north (Altamont-Bluebell field area). The presence of Class B (associated?) gas in shallow, thermochemically immature reservoirs in the area of the Red Wash field indicates extensive lateral migration from the Altamont-Bluebell field area. This interpreted direction of gas migration (eastward) is the same as that for fluid flow as interpreted from fluidpressure data.

Plots of porosity values versus vitrinite reflectance values $\left(R_{m)}\right.$ for Mesaverde Group sandstones from the Piceance and Uinta basins, between 0.70 percent and 1.8 percent and in the window of hydrocarbon generation, show that porosity values in Cretaceous rocks do not decrease as thermal maturity increases. Overpressured, gas-saturated Mesaverde sandstones are likely to have porosity values in the 5 percent to 9 percent range.

A large area of overpressured Cretaceous strata probably underlies the north-central part of the Uinta Basin. Wells drilled in the areas where $R_{m}$ at the base of the Mesaverde is greater than 1.1percent should have the best potential for future gas production. Overpressured gas reservoirs $\left(R_{m}>1\right.$.1 percent) are likely to have no free water and to be covered and bounded on the margins by successive zones of mixed water and gas ( $R_{m} 1.1$ percent to 0.75 percent), and of water only $\left(R_{\mathrm{m}} 0.75\right.$ percent).

\section{INTRODUCTION}

Gas-bearing Cretaceous and Tertiary strata have been identified in drill holes distributed over much of the eastern and north-central parts of Uinta Basin, Utah (figs. 1, 2, and 3). Most known accumulations of nonassociated gas are associated with fields that occur east of the Green River where they are found within rocks of the Upper Cretaceous Mesaverde Group, uppermost Cretaceous to lower Eocene North Hom
Formation, and the Paleocene and Eocene Wasatch, Colton, and Green River Formations (figs. 4, 5, 6, and 7). However, the Altamont-Bluebell producing complex lies west of the river and contains a major accumulation of gas associated with oil developed within Paleocene and Eocene reservoirs of the Colton (Wasatch of some authnrs), and Green River Formations.

The Tertiary tight-gas reservoirs have historically been the focus of exploration for gas in the Uinta Basin. The vast majority of successful tight-gas completions have been in Tertiary strata. Successful completions in Cretaceous rocks are few and data sufficient for analysis of Cretaceous units are likewise sparse. A number of companies are currently very active in Wasatch gas exploration. Some are attempting to complete in Upper Cretaceous Mesaverde gas-bearing rocks where they underlie the productive Tertiary units and where gas from each formation can be commingled. Spencer and Wilson (1988) and Nuccio and others (1991) (also see Spencer and Law, 1988; Law and others, 1989) suggest that comparison of the geologic setting of the deeply-buried rocks of the Uinta to those of other Rocky Mountain basins, indicates that much of the Mesaverde Group in undrilled areas of the basin will be prospective for gas.

A number of informal expressions such as tight, unconventional, and conventional have been used to characterize the gas reservoirs of the basin. The distinctions among the terms are vague and poorly defined. The terms represent rather arbitrary distinctions and applications. However, in general, Uinta oil

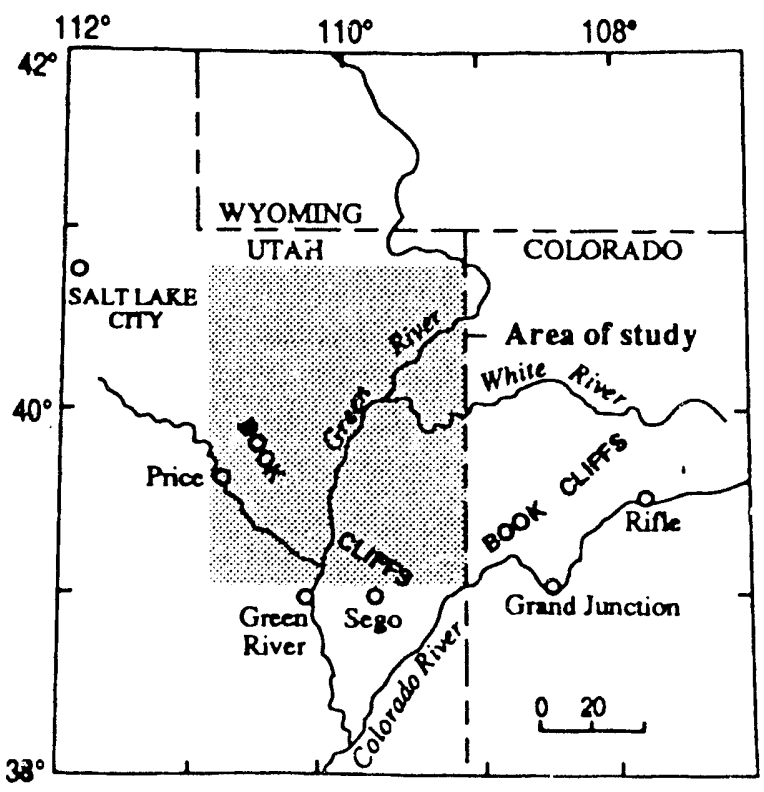

Figure 1. Index map of noriheast Utah and northwest Colorado. Study area is shaded. 


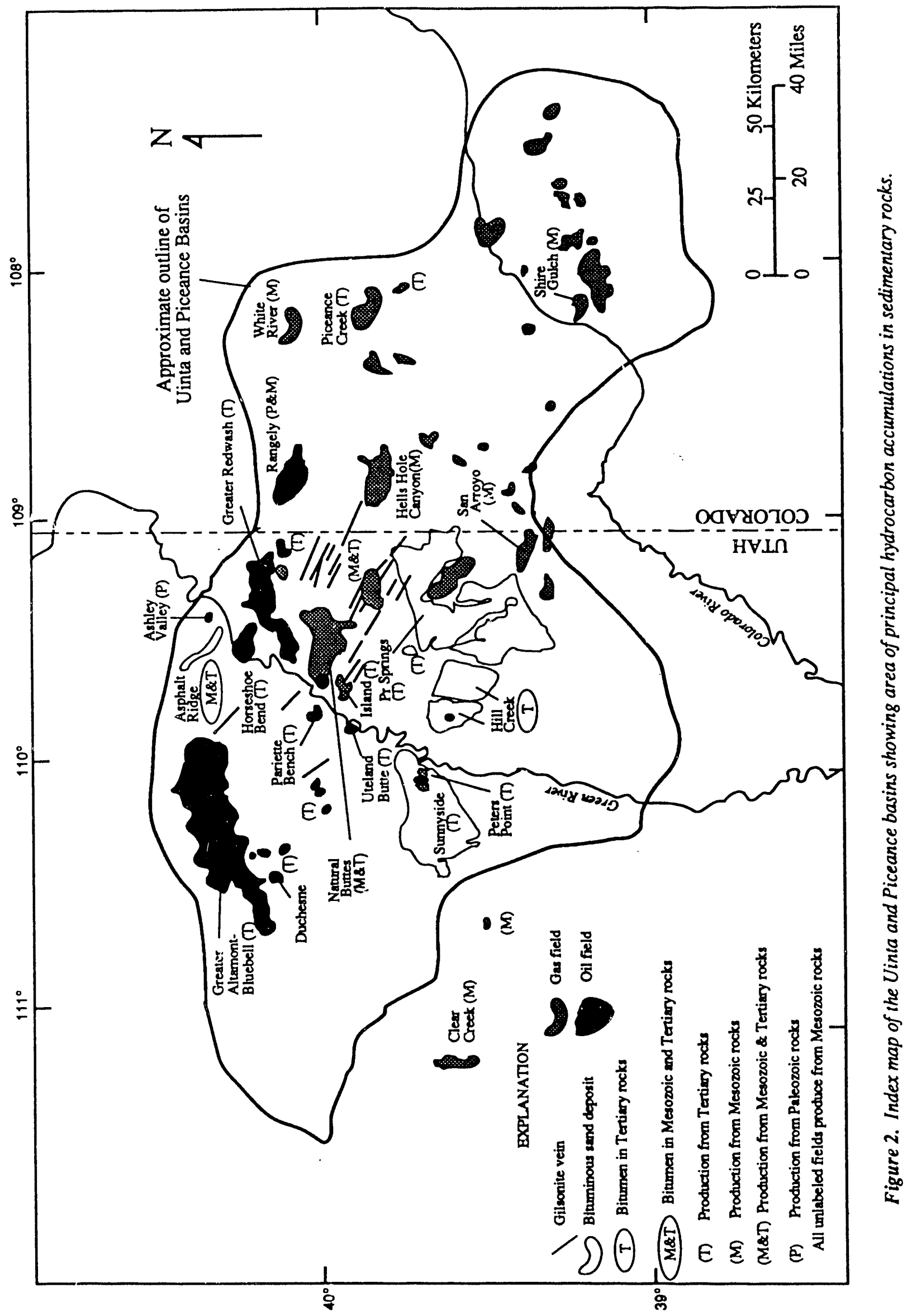




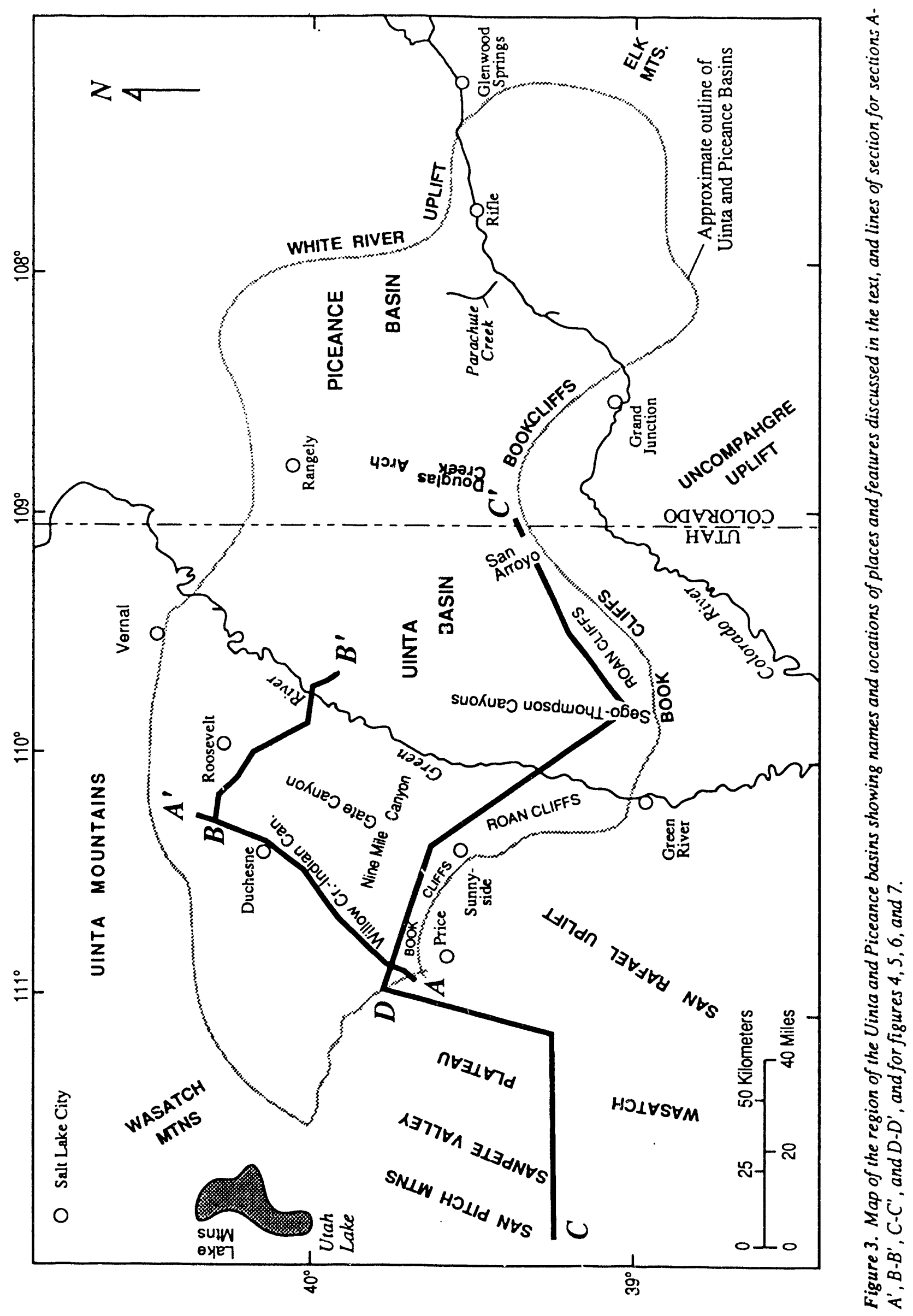




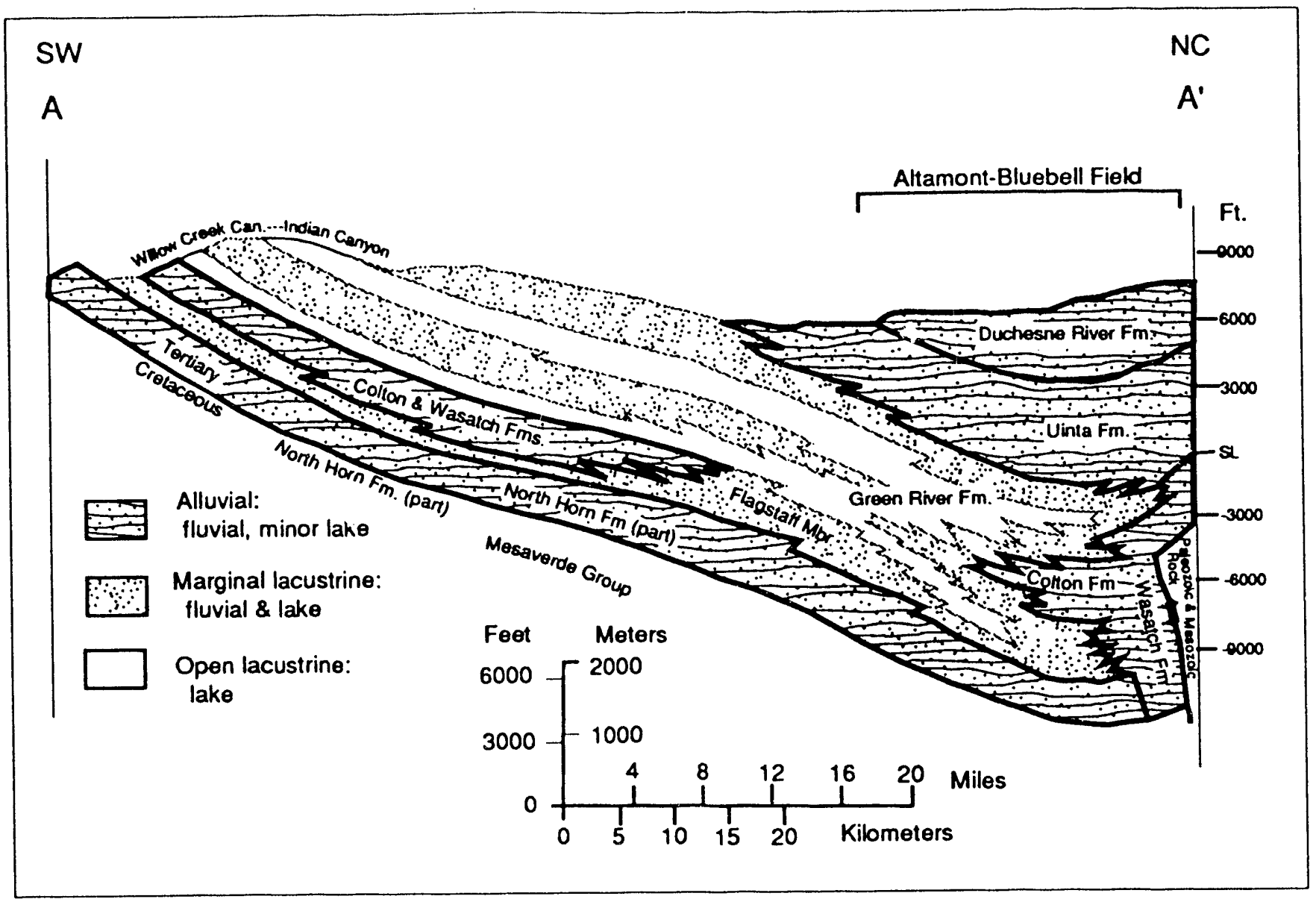

Figure 4. Generalized structural-stratigraphic cross section A-A' which extends from outcrops on the southwest flank of the Uinta Basin, through Duchesne and Altamont-Bluebell oil fields, to the north-central part of the basin (modified from Fouch. 1975). Stratigraphic names projected into the line of section are those commonly assigned to the units and follow the usage of Fouch (1976), Ryder and others (1976), Bryant (1991), and Bryant and others (1989). See figure 3 for approximate line of section and figure 2 for fields. Patterns show environment of deposition for sediments.

and/or gas reservoirs have been characterized as being unconventional in areas where they seem to form a complex where few wells are economic, and where the productive section is composed of seemingly unpredictable discontinuous porous and nonporous zones within an overall sequence of impermeable rocks (Keighin and Fouch, 1981; Pitman, Fouch and Goldhaber, 1982). Conversely, the expression conventional has been applied to those reservoirs that form a complex of relatively predictable and relatively continuous zones of porous and permeable units for which hydrocarbon discoveries are equally predictable, and economically viable wells are numerous. This approximate characterization was used by Spencer and Wilson (1988) in their assessment of the basin's conventional oil and gas resources. It is clear that the unconventional can become conventional with changes in economic, experience, and technology factors.
The Federal Energy Regulatory Commission Order 99 (1980) defined a tight reservoir as one whose in situ permeability throughout the pay or gas producing sectior: :s 0.1 md or less to gas (exclusive of fracture permeability). As a result, many Uinta Basin gas reservoirs have been clescribed as being tight and have qualified as being tight, although core-plug porosity values for these tight reservoirs vary greatly and range from 1-16 percent (Boardman, C.R., and C.F. Knutson, 1980; Knutson, C.T., Hodges, L.T., and Righter, S.B., 1981; Keighin and Fouch, 1981; Fouch 1985; Pitman, J.K., Anders, D.E., Fouch, T.D., and Nichols, D.J., 1986).

This report characterizes Upper Cretaceous Campanian and Maastrichtian, snd lower Tertiary gasbearing rocks in the Uinta Basin with special emphasis on those units that contain gas in reservoirs that have been described as being tight. The report was prepared 


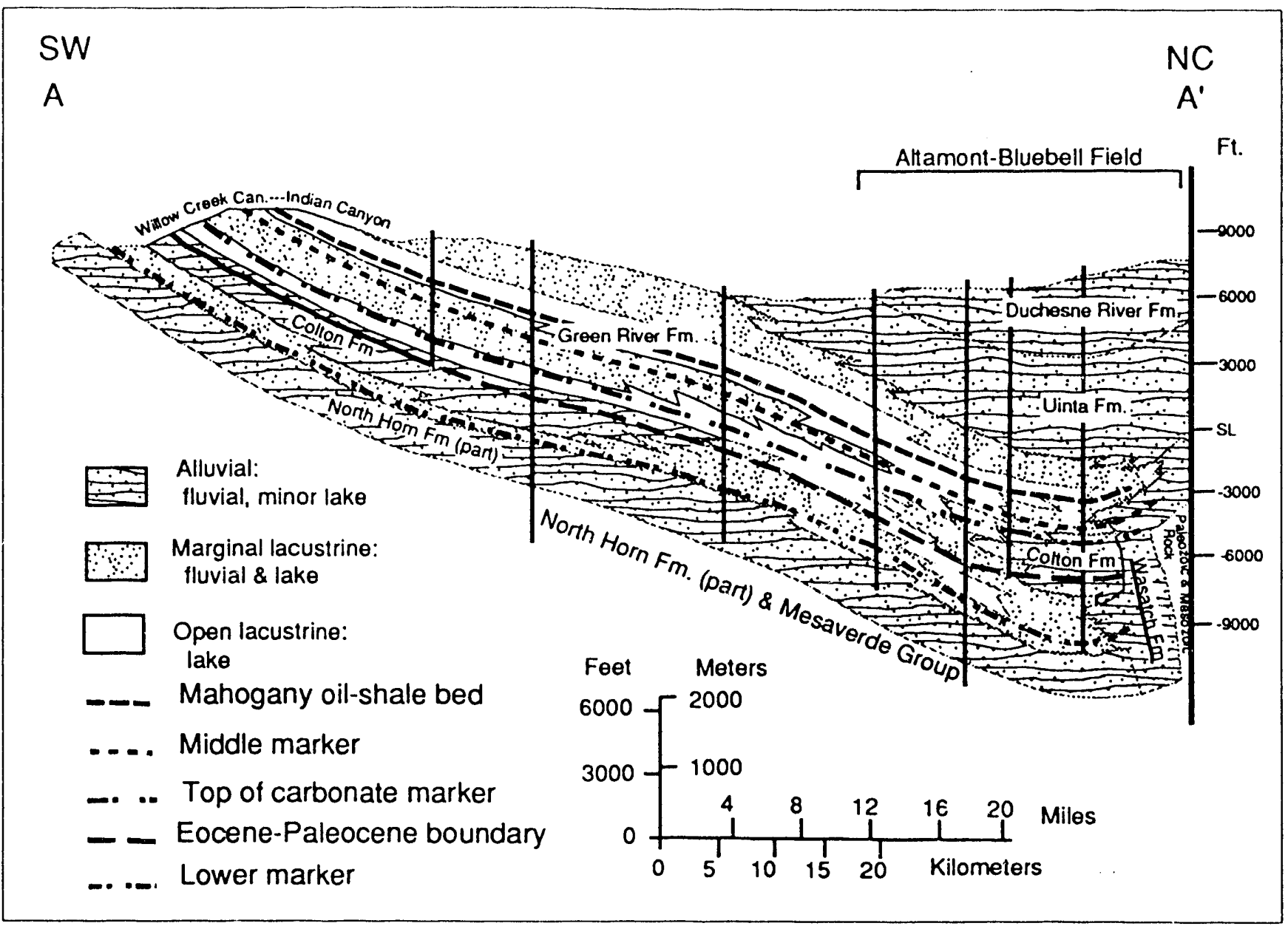

Figure 5. Generalized structural-stratigraphic cross section $A-A^{\prime}$ which extends from outcrops on the southwest flank of the Uinta Basin, through Duchesne and Altamont-Bluebell oil fields, to the north-central part of the basin (modified from Fouch, 1975). Section shows common stratigraphic markers projected into the line of section. See figure 3 for approximate line of section and position of control points.

for the U.S. Department of Energy whose Westem Tight Gas Sandstone Program cofunded much of this research in conjunction with the U.S. Geological Survey's Evolution of Sedimentary Basins, and Onshore Oil and Gas Prograrns.

\section{GAS-BEARING STRATA}

\section{Regional Framework}

Most reservoirs are lenticular fluvial sandstones that occur within two major sedimentary systems. Figure 8 illustrates these two systems in a chronostratigraphic cross section C-C' that extends from exposures in central Utah to those along the Book and Roan Cliffs that mark the southern edge of the Uinta Basin. In the first sedimentary system, Upper Cretaceous impermeable fluvial rock reservoirs occur within the Blackhawk, Castlegate, Sego, Neslen, Farrer, Tuscher, and Price
River Formations which are assigned to the Mesaverde Group. A second sedimentary system consists of Tertiary rocks that occur in the Maastrichtian to lower Eocene North Horn Formation, and in the Paleocene and Eocene Wasatch and Colton Formations. Locally, fluvial sandstones of the Eocene part of the Green River Formation are tight-gas reservoirs but many operators frequently group the fluvial Green River reservoirs with those of the Wasatch Formation when applying stratigraphic termin'slogy.

Stratigraphic identifications used in making maps and sections are based on comparison of the wirelinelog character (signature) to that of published identifications (character of tops and markers), and to other surface and subsurface lithologic characteristics unique to individual formations. The stratigraphic data base includes more than 1,500 identifications by us and more than 23,000 from other sources. In general, we use for the stratigraphic identities the subsurface mark- 
B

$$
\text { NC }
$$

Altamont-

Bluebell

Field

EC

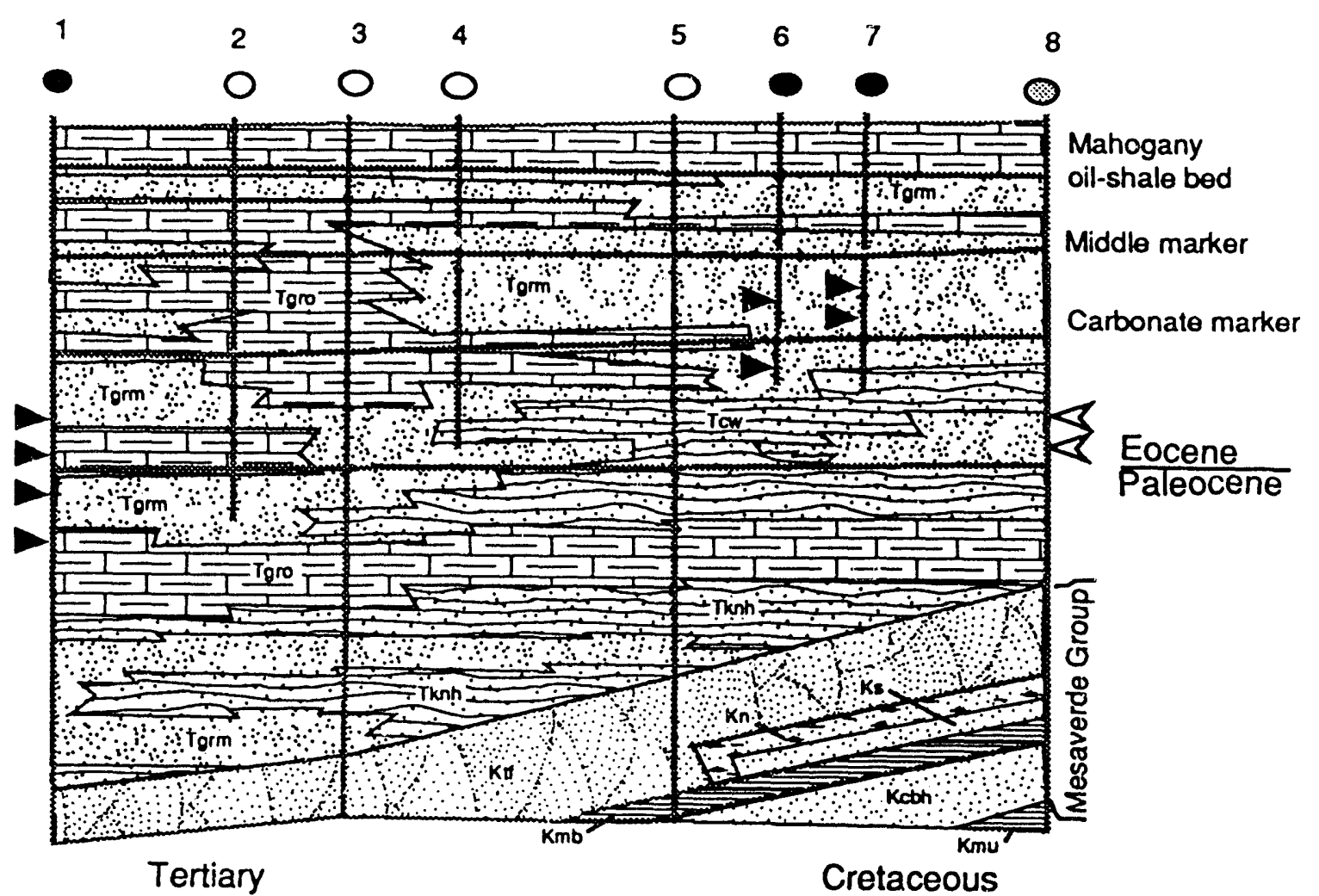

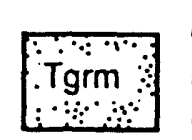

Green River Fm; Marginal Lacustrine; Mixed lake \& Fluvial

Colton \& Wasatch Fms;
Alluvial

ETknh- Tertiary \& Cretacoous;

North Horn Fm;
Alluvial \& minor lake

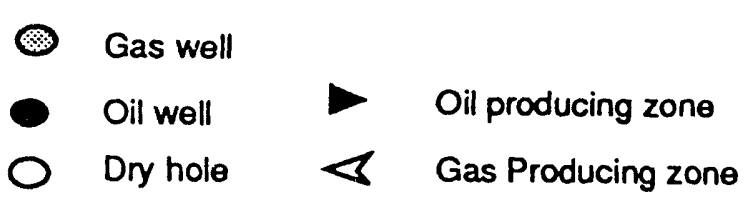

\section{Cretaceous}

Nonmarine

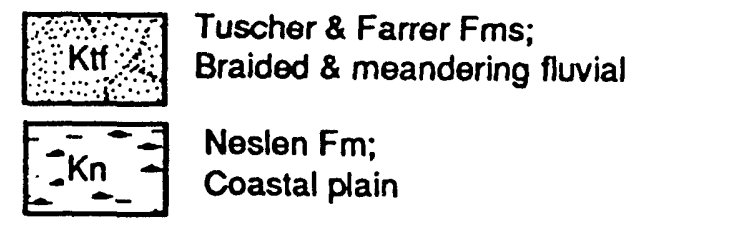

Marine

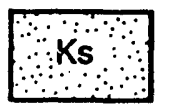

Sego Fm;

Shore, nearshore

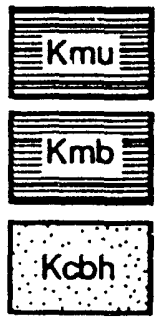

Mancos Shale

Open marine

Buck Tongue of
Mancos Shate
Castlegate SS. \&
Blackhawk Fm
Littoral and Shelf

Figure 6. Stratigraphic cross section $B-B^{\prime}$ that extends from the Altamons oil and gas field in the north-central part of the basin to the Island gasfield (modified from Pitman and others, 1982). Subsurface markers of Fouch (1975, 1981), and Fouch and Cashion (1979) are shown to provide a basis for comparison. Section and control points are shown in large scale and detail by Fouch and Cashion (1979). Beds in Island gasfield are typical of those in the Natural Buttes gas field, and generally of the basin's region of gas production from the tight Upper Cretaceous and Tertiary strata east of the Green River. See figure 3 for line of section and figure 2 for site of oil and gas fields. 


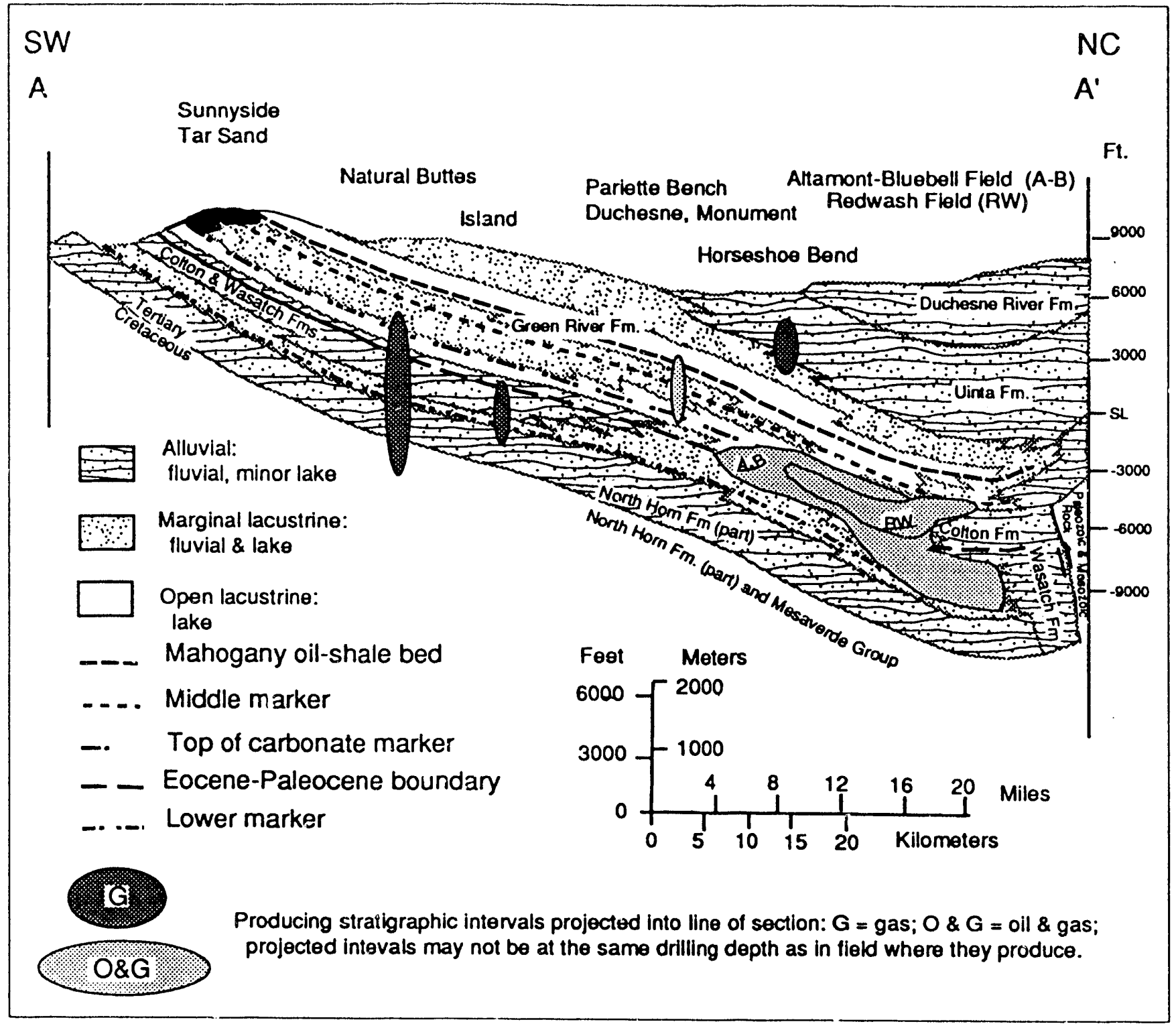

Figure 7. Cross section A-A' which extends from oulcrops on the soulhwest flank of the Uinta Basin, through Duchesne and Altamont-Bluebell oil fields, 10 the north-central part of the basin (modified from Fouch. 1975). Section shows producing intervals for many of the basin's fields projected into the line of section. Stratigraphic markers are those commonly assigned to the units and follow the usage of Fouch. (1975), Fouch (1976), Ryder and others (1976), and Fouch, 1981. See figure 3 for line of section, and figure 2 for siles of hydrocarbon accumulations.

ers defined, identified, and illustrated in Chatfield (1972); Keighin and Fouch (1981); Fouch (1975, 1985), Fouch and others (1976, 1981, 1983); Fouch and Cashion (1979); Ryder and others (1976); Cashion (1972); Cashion and Donnell $(1972,1974) ;$ Hendel (1957); Pitman and others (1982); Pitman and others (1986); R.C. Johnson (19'85, 1989); Speaker (1946); Fisher and others (1960); Owen, and Whitney (1956); Lucas and Drexler (1976); Picard (1957); Osmond (1985); Colbum and others (1985); and Walton (1964).

This stratigraphic subdivision serves as a frame of reference for quantifying the number of reservoir sand- stone units, their porosity and permeability values, and their geometries. The subdivision has been used to construct several maps for use in the assessment of gas resources. These maps and sections help characterize and quantify that part of the stratigraphic section that either is known to be, or may be, gas-bearing.

The uppermost Cretaceous and lowermost Tertiary strata dip between $4^{\circ}$ to $6^{\circ}$ north from the Book and Roan cliffs and are penetrated in the subsurface of the north-central part of the basin at the AltamontBluebell complex between 10,000 ft and $20,000 \mathrm{ft}$ (see figs. $4,5, \& 6$ ). 


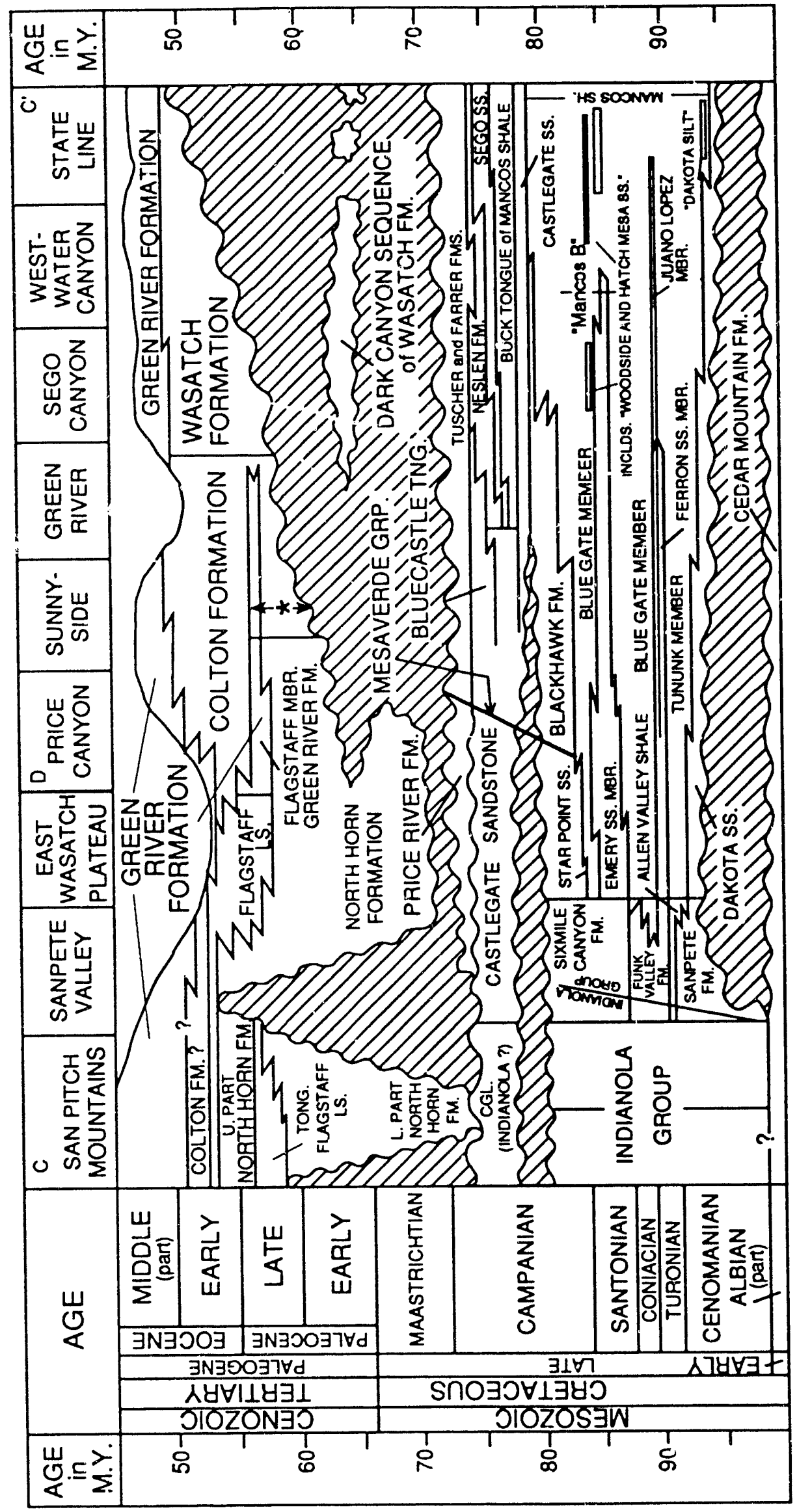

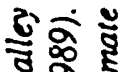

32

ชั้

है के

ई ำ

弯范

ड़ छे

路

ธิ 5ั

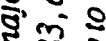

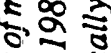

के

帘

造

ș

Q

है

농

5

洁

क्ष

我 5

羟

ฐ ฐ

บิ

产

डิ

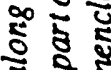

E

5.

कृ 웅

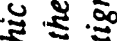

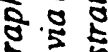

\$.

is :

도

55

Uิ

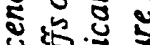

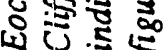

ซั

吅 5

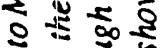

을

昰击

₹ 5

$\infty$ is

纹 氜

象卷 
Figure 9 is a map that shows major faults and gilsonite veins in fractures in the Uinta Basin. Information on the structural composition of the basin was derived primarily from Cashion (1973), Campbell (1975), Ryder and others (1976), Fouch (1975), Rowley and others (1985), and Bryant (1991).

Much of the gas production is from fields developed along the trace of faults and fractures in the eastem part of the basin (also see fig. 2). The trend of the gilsonite veins and several of the fault zones in the southem and eastem parts of the basin appear to overlie and coincide with the position of the Douglas Creek, Seep Ridge, and Gar Mesa faults (see figure in Stone, 1977). Stone (1977) demonstrated that these major faults developed along the north and northeast flanks of the Uncomphagre uplift in the region of the Uinta Basin during the late Paleozoic and Mesozoic. We suggest that the structural discontinuities that cut the Cretaceous and Tertiary units of the basin represent reactivation of buried structures associated with the ancestral Uncomphagre. We believe that gas has migrated from Cretaceous source rocks through a permeable network of faults and fractures in Cretaceous and Tertiary strata to the slightly overpressurred to normally pressured reservoirs of the Mesaverde Group and Wasatch Formation in the eastem and southem parts of the basin.

\section{Campanian and Maastrichtian Cretaceous Rocks}

Paleogeographic maps and cross sections characterize and portray the primary sedimentologic and stratigraphic composition of the basin's hydrocarbonbearing strata. Figure 10 is a detailed chronostratigraphic diagram extending from central Utah to the boundary between Colorado and Utah (C$C^{\prime}$ on fig. 3). Figure 11 is a stratigraphic cross section extending east from Price Canyon to east of the Sego Canyon (D- to near C' on fig. 3). These diagrams illustrate the depositional, stratigraphic, and ternporal framework of Campanian through Eocene rocks in the Uinta Basin. In addition, they provide a basis for comparison of paleogeographic maps for selected time intervals such that the three-dimensional framework of the area can be realized.

Figures 12, 13, and 14 are paleogeographic maps that correspond to periods of time represented by the Westem Interior molluscan fossil zones and their absolute age equivalents (see fig. 10). The figures collectively indicate the stratigraphic and sedimentologic composition of Mesaverde rocks in the basin. Penetrations of the Mesaverde Group in regions other than at the margiris of the basin are few. In addition, most Mesaverde tests lie east of the Green River. Successful completions in Cretaceous rocks are few and data sufficient for analysis of Cretaceous units are likewise sparse. Some operators are attempting to complete in Upper Cretaceous Mesa:erde gas-bearing rocks where they underlie the productive Teriary units and where gas from each formation can be commingled. However, in general, most gas encountered in Uinta Basin tight sandstone of Cretaceous age has been in rocks deposited in braidplain and coastal-plain settings. A later discussion in this paper indicates that coastal plain units that contain abundant woody organic matter are a major source of gas in the basin.

Figure 15 is a structure contour map of the top of the Upper Cretaceous Mesaverde Group. The westernmost part of the basin has been excluded from the map area because it contains allochthons of the thrust belt. The sequence of reservoirs contained within the Mesaverde section is anticipated to contain the principal Cretaceous gas-bearing unit in much of the basin. Figure 16 maps the base of that par of the Upper Cretaceous Mesaverde section that we are considering in this study. For purposes of this study, the map was constructed from interpretations of the base of the Star Point Sandstone or Blackhawk Formations of the Mesaverde Group, or the top of the Mancos Shale. These markers represent a west ward-downstepping set where each marker is progressively older. Figure 17 is an isopach map of the Mesaverde Group. Analysis of information provided in figures 10 through 14 indicate that less than 10 percent of the Mesaverde section in the Uinta Basin is coinposed of marine rock. In addition, for most areas in the study area, more than 70 percent of the Mesaverde Group is composed of sandstone with the remaining portions being of mudrock, coal, and sandy siltstone.

\section{Paleocene and Eocene Rocks}

Paleogene Lake Uinta strata in the Uinta and Piceance basins, Utah and Colorado, record both longand short-term changes in climate and tectonic regime (Fouch and Pitman 1991; Fouch and Pitman, in press). Large, tectonically induced reconfigurations of the lake gave rise to relatively thick (few to several thousand feet), lithologically distinct stratigraphic sequences. Simultaneous changes in climate brought on by variations in solar radiation initiated very rapid rises and falls of the lake, as well as shifts in alkalinity and salinity of the water that resulted in the development of sedimentary and carbonate-geochemical cycles 


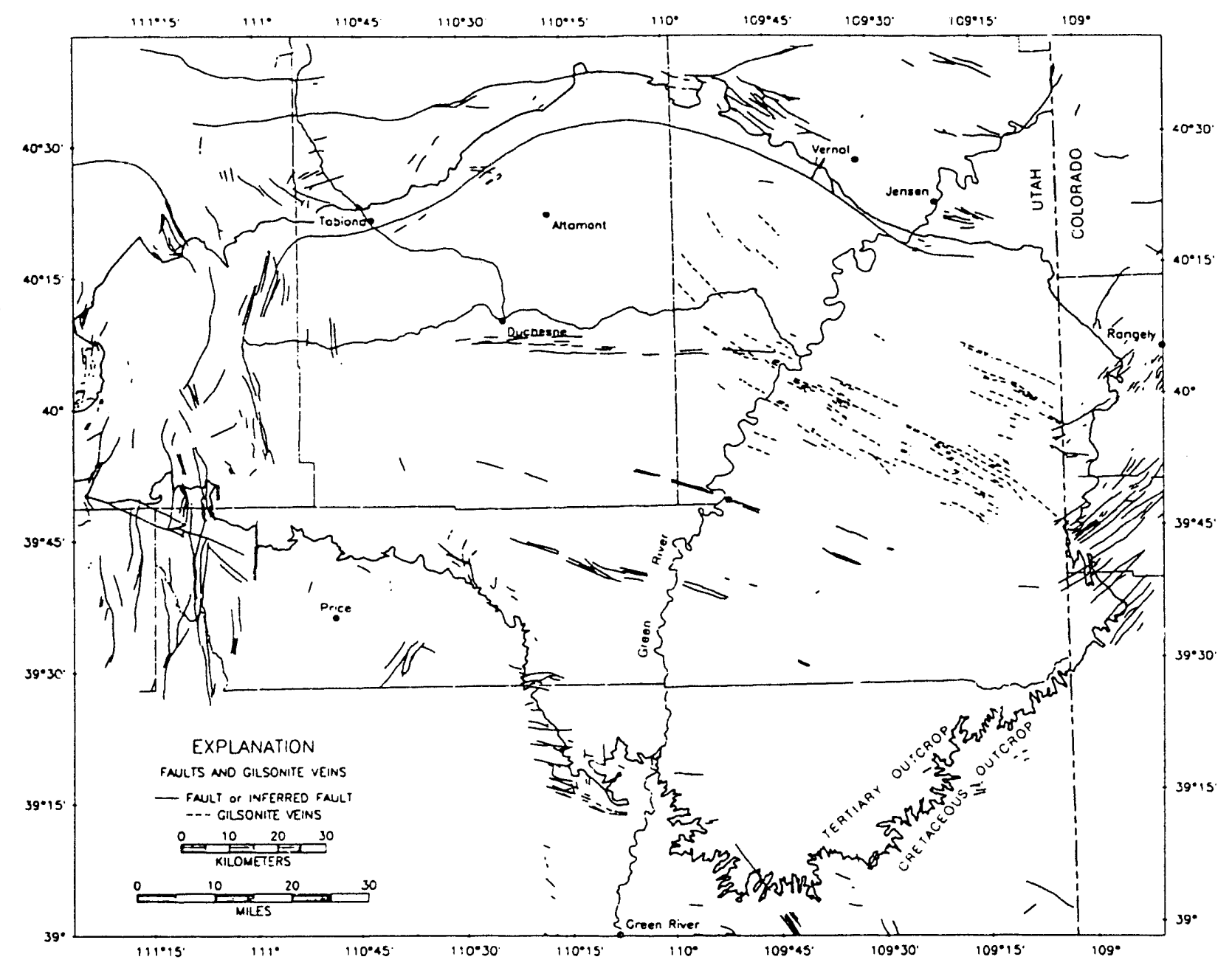

Figure 9. Preliminary map showing gilsonite veins (dashed lines) and major faults (solid heavy lines) in Upper Cretaceous and Tertiary rock of the Uinsa Basin (from Fouch and others, 1991). Faults are taken from Campbell, 1975; R.W. Scott, R.C. Johnson, and M.P. Pantea, personal commun., 1990; and LF. Hintze, 1980.

(parasequences) of up to tens of feet thick. Tectonically induced stratigraphic sequences represent environments that lasted several million years whereas climate-induced parasequences lasted several thousand years: together they brought on rapidly changing conditions. The resuiting lake deposits which reflect both tectonic and climatic cycles, now constitute the principal source and reservoir rocks for petroleum in the Uinta Basin.

Middle Paleocene to late Eocene lake deposits are characterized by halite, sodium bicarbonate salts, and kerogen-rich shales containing organically derived carbonate minerals, indicating a highly organically productive, closed hydrologic system during much of the existence of the lake. Strata are cyclic: some cycles extend over a few thousand feet of section, corresponding to a time span of several million years while other cycles occur within fractions of an inch and probably represenit approximately 1 year.

Throughout the lake system, a cyclic depositional sequence in a marginal-lacustrine setting from oldest to youngest consists of: (unit 1) mud-supported, laminated carbonate rock or oil shale with a flooding surface at the base shoaling to an ostracod-, pisolite-, and (or) oolite-grainstone; (unit 2) mudcracked mudstone and (or) stromatolitic carbonate; (unit 3) mudcracked overbank mudstone or sandstone; and (unit 4) coalesced channel sandstone that locally eroded down to the underlying carbonate (unit 1) and aggraded laterally to form a composite sandstone sheet. Each 


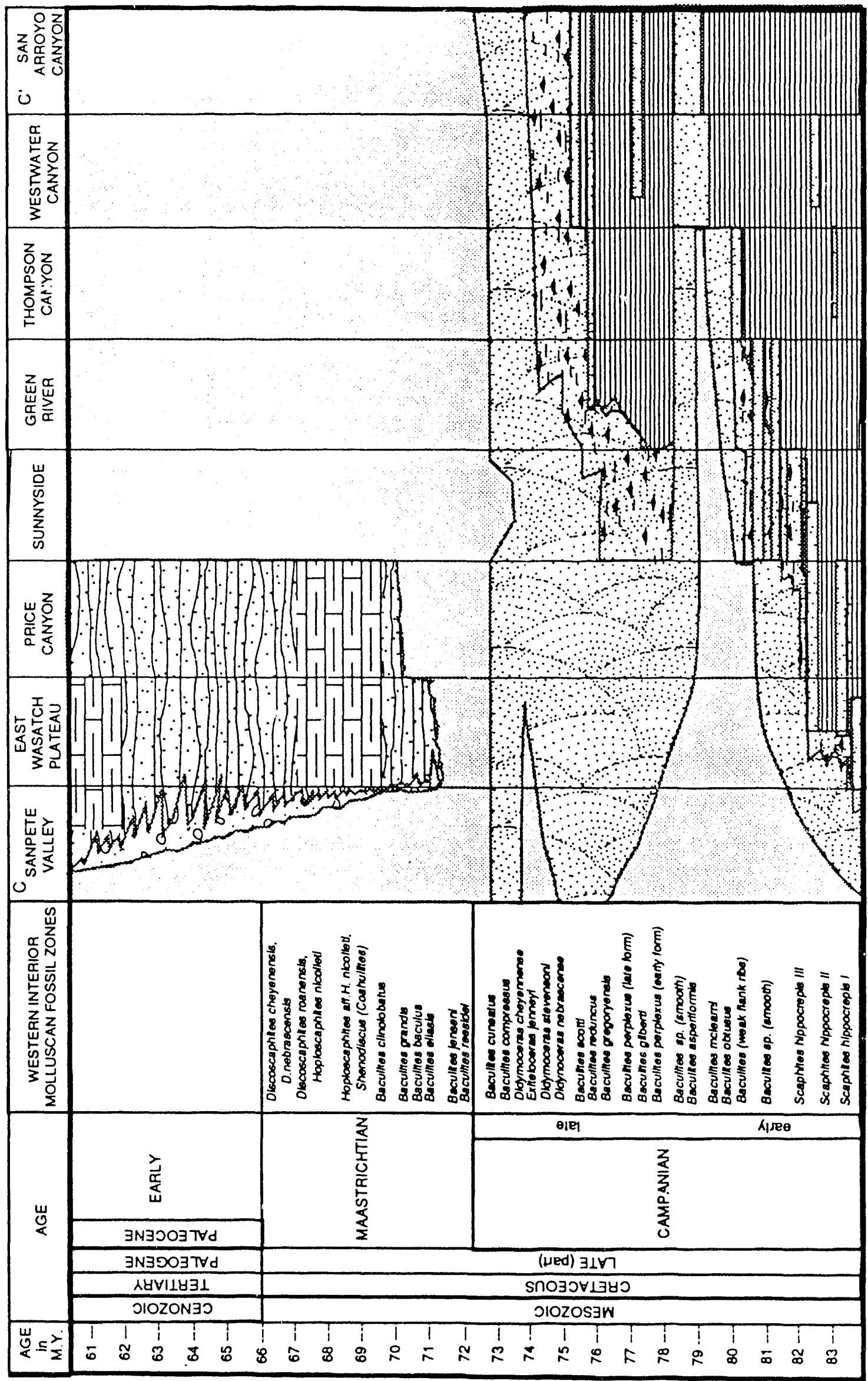

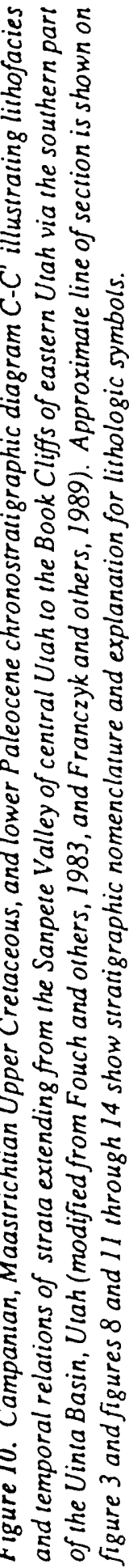




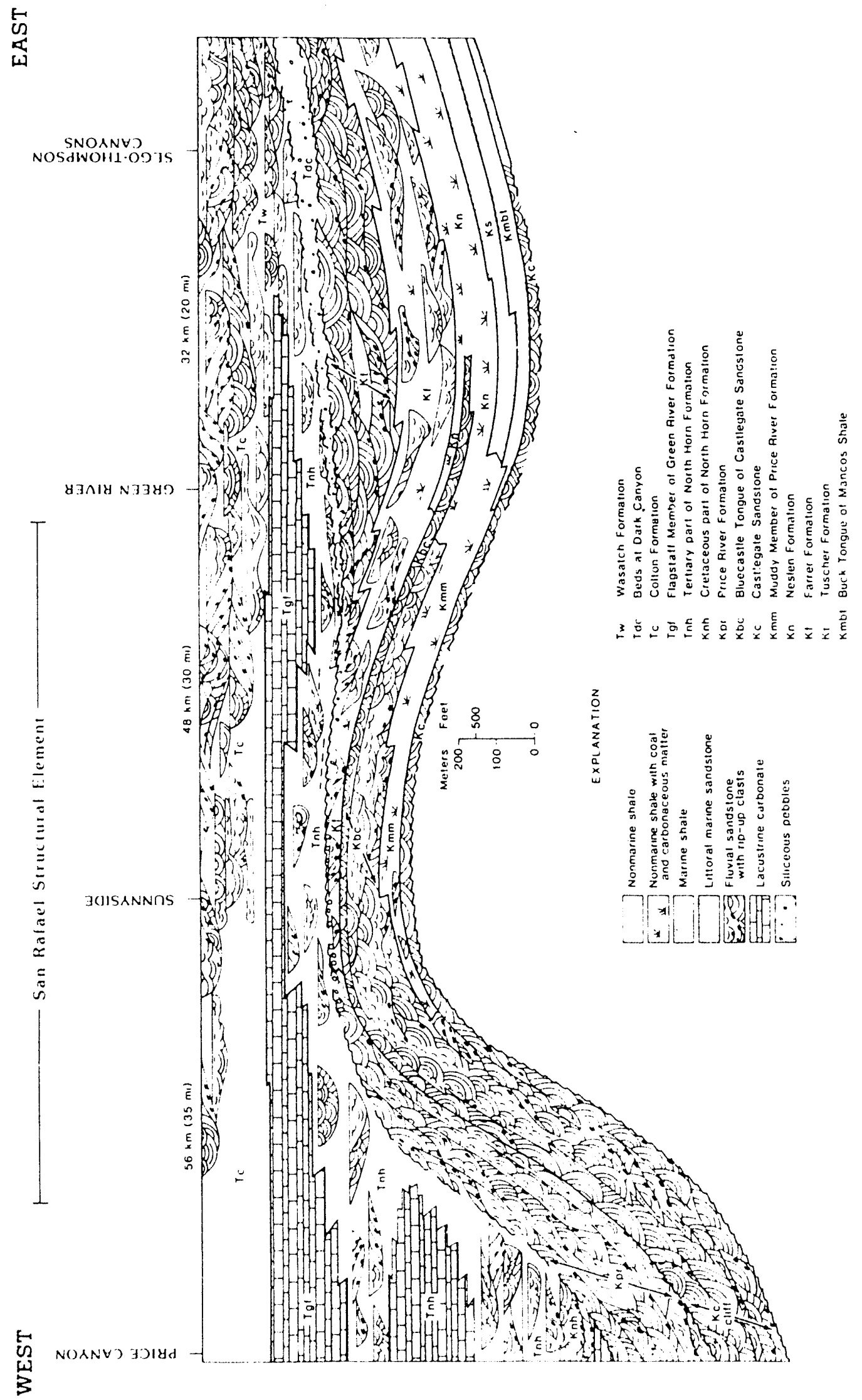

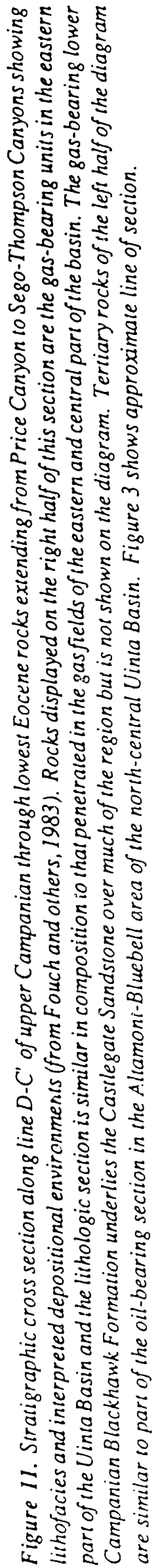




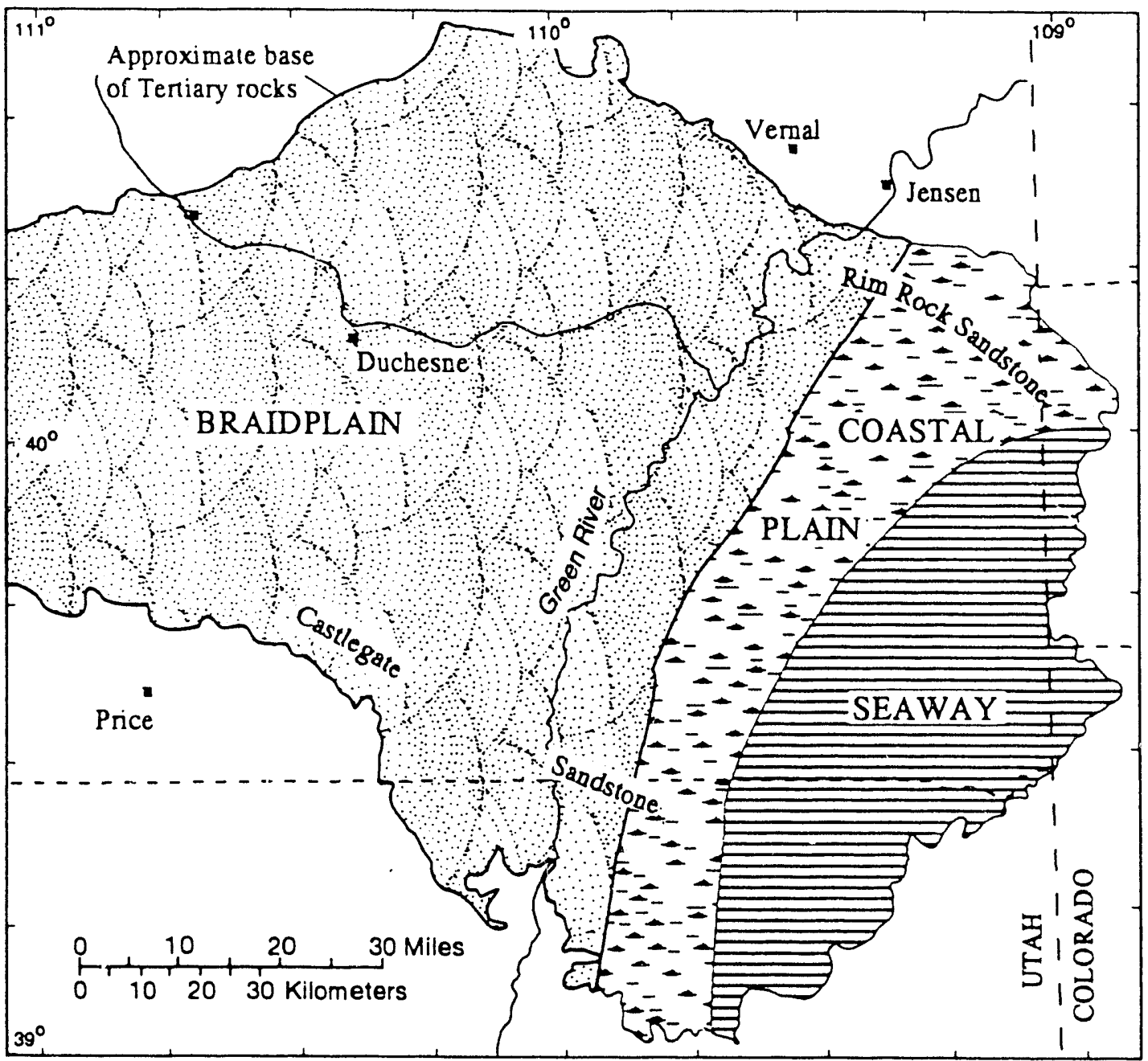

Figure 12. Paleogeographic map including Mesaverde Group depositional-facies at the time of the Campanian marine fossil zone of Baculites asperiformis and its nonmarine extensions (modified from Fouch and others, 1983). Refer to figure 10 for the temporal position of the fossil zone.

interval within the sequence can vary greatly in thickness and areal extent depending upon its position within the depositional system.

Major open-lacustrine units reflect expansions of the lake such as those associated with the carbonate marker, Flagstaff Member, and Mahogany oil-shale zone of the Green River Formation. They formed in response to episodes of tectonic reactivation of regional faults such as the subsurface Basin Boundary fault of Campbell (1975) along the north flank of the Uinta Basin. Large reconfigurations of the Lake Uinta system are defined by unconformity-bounded sequence boundaries. Strata that bracket these boundaries represent major cycles and consist of thick, lithologically distinct tongues of open-lacustrine, marginal-lacustrine, and alluvial rock extending over large regions of the depositional system. Flooding surfaces document major episodes of shore transgression and record deposition of open-lacustrine, mud-supported, laminated carbonate rocks that make up the condensed section for each sequence.

Green River Formation strata contain numerous cycles of smaller dimensions than the large regional sequences just discussed. Recurrent and continuing climate change initiated very rapid expansions and contractions (and rises and falls) of the lake as well as shifts in alkalinity and salinity of its water. These changes resulted in small- to large-scale sedimentary and carbonate-geochemical parasequences within the larger regional sequences. Solar radiation-induced sedimentary and geochemical cycles are similar in style to tectonic cycles, except that they commonly are recorded within a sedimentary thickness of 10-100 ft and represent a few thousand to tens of thousands of years. In kerogenous open-lacustrine source rocks, carton and oxygen isotope profiles for calcite and 


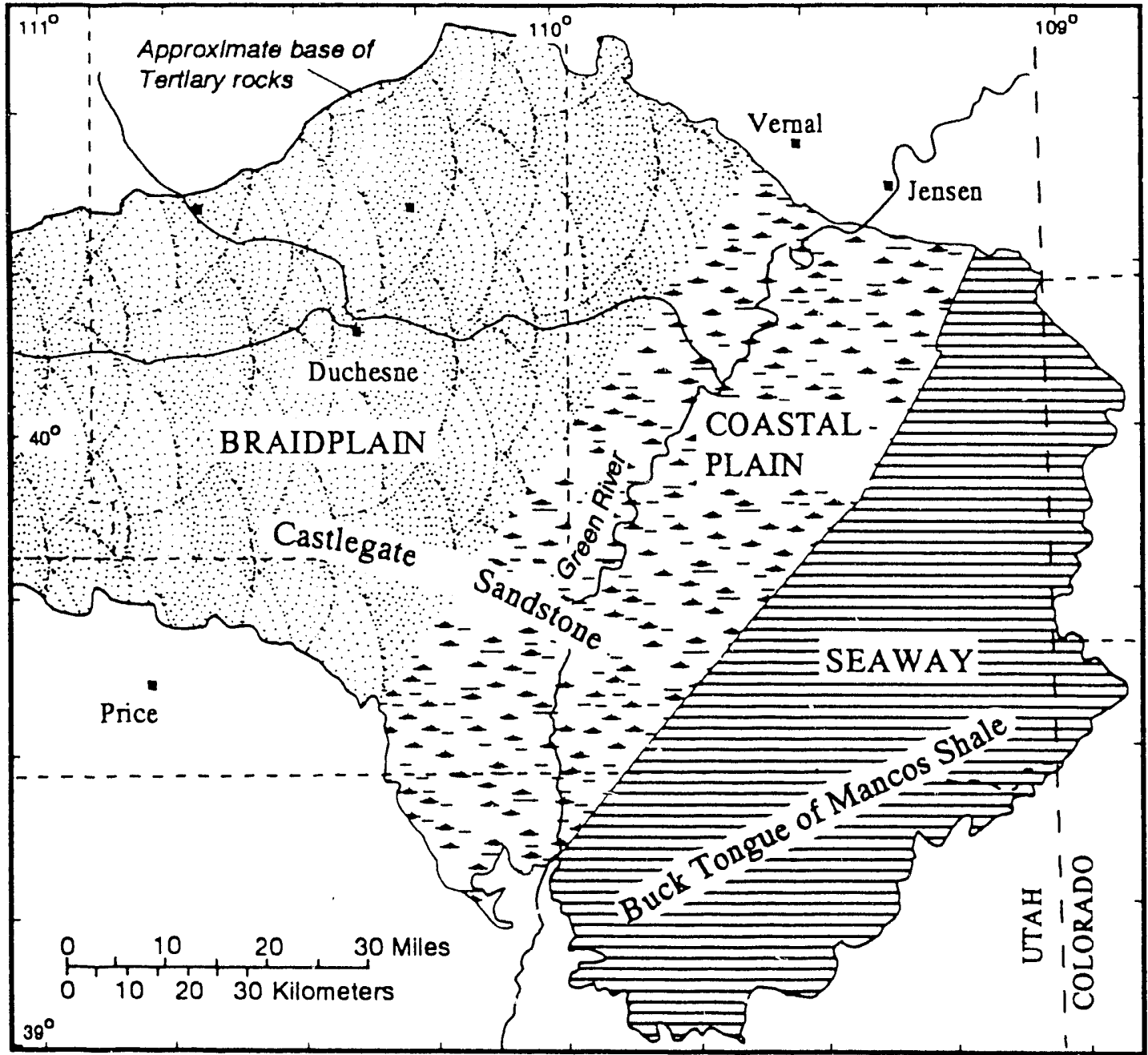

Figure 13. Paleogeographic map including Mesaverde Group depositional-facies map at the time of the Campanicn marine fossil zone of Baculites perplexus and its nonmarine extensions (modified from Fouch and others, 1983). Coastal-plain rocks east of the Green River have yielded numerous gas shows in subsurface tests and organic matter within them is thought to be a major source of gas in the region. Refer to figure 10 for the temporal position of the fossil zone.

dolomite show generally synchronous geochemical cycles in which positive and negative excursions correspond to cyclic variations in organic carbon content and to changes in lithology. Small-scale carbon isotope cyclicity in carbonate matter documents salinityinduced changes in primary organic matter productivity and the amount of reduced carbon available for carbonate precipitation via methanogenesis. Largescale carbon enrichment trends on carbonate curves record the effects of progressive acetate metabolisin on the isotopic evolution of the inorganic carbon reservoir in a restricted, extended-residence-time system. Smallscale cyclic variations in oxygen in carbonates are related to climate-induced salinity changes that resulted from alterations in hydrolcgic balance during the lake's history. Major oxygen trends on the carbonate curves correspond to large-scale variations in lake level and salinity due to large alterations in inflowevaporation balance coincident with major paleoclim ate changes.

The principal source and reservoir rocks for Tertiary strata are controlled by the geometry of the sedimentary cycles. Marginal-lacustrine channel sandstones comprise the principal reservoirs for oil and associated gas in Tertiary strata, and alluvial channel sandstones are the basin's principal Tertiary (and Cretaceous) reservoirs for nonassociated gas. Tertiary marginal-lacustrine channel sandstones in surface exposures on the basin's south flank are parts of the parasequences described above. They can be separated into two types with respect to geometry and width/depth (W/D) ratios (Szantay and others, 1989; Fouch and others, 1990). The channel sequences (depositional unit 4 above) occur within the 


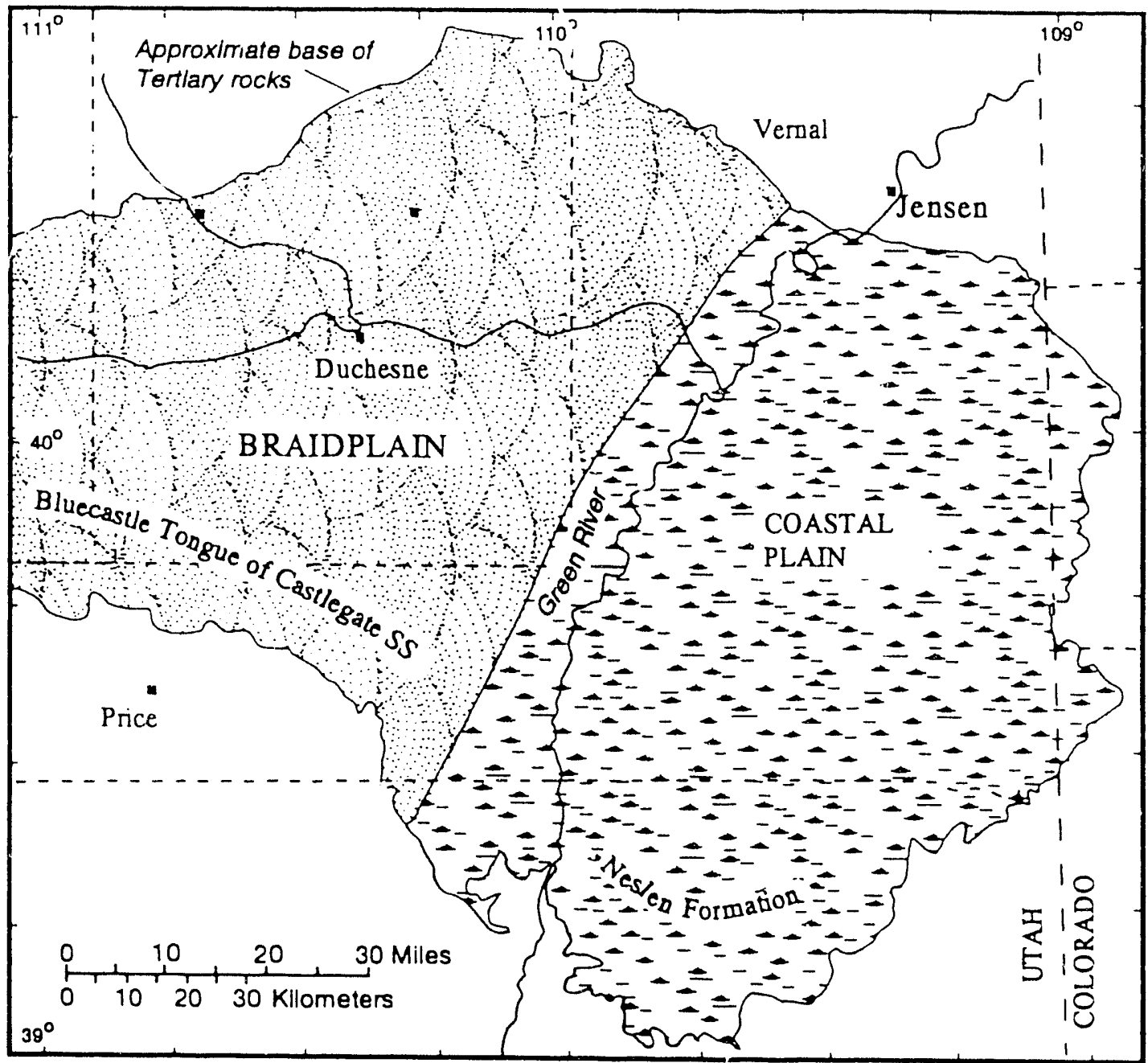

Figure 14 a. Paleogeographic map including Mesaverde Group depositional-facies at the time of the Campanian marine fossil zone of Didymoceras nebrascense and its nonmarine extensions (modified from Fouch and others, 1983). Coastal-plain rocks east of the Green River have yielded numerous gas shows in subsurface tests and or ganic matter within them is thought to be a major source of gas in the region. Rocks of the braidplain facies have yielded gas shows in tests along the southern margin of the basin. Refer to figure 10 for the temporal position of the fossil zone.

parasequences described above. Type I sandstones are characterized by a tabular geometry controlled by a planar lower bounding surface, an average channel depth of $7.6 \mathrm{~m}$, and an average $\mathrm{W} / \mathrm{D}$ ratio of 8.9 . The planar channel bottom results from underlying resistant carbonate units whose early lithification restricted downcutting and caused more extensive lateral aggradation compared to that of streams forming type II bodies. Type II sandstones are characterized by a lenticular geometry, with an average channel depth of $5.7 \mathrm{~m}$, an average $W / D$ ratio of 3.6 , and a concaveupward lower bounding surface. The absence of resistant carbonate rocks (because of erosion or nondeposition beyond the limits of the lake) underlying streams that deposited type II bodies resulted in stream channels that, although similar in size, did not migrate laterally as much as those of type I. As a result, the size of individual channel sandstone bodies (and therefore reservoir units) is largely dependent upon induration of the substrate across which streams flowed.

It should be noted, that Ryder and others (1976) distinguished between fluvial channels formed at or near a lake margin (fluvial-lacustrine channels) and those located in nonlacustrine alluvial-plain settings (fluvial-alluvial channels). Both channel types can represent manifestations of depositional unit 4 (above) within a marginal-lacustrine depositional sequence or its peripheral alluvial-facies equivalent.

In the Uinta Basin, most oil and associated gas are recovered from pores (most being secondary) in the basal parts of marginal-lacustrine channel sandstone units that are intercalated with carbonate and gray and green mudstone units (Fouch, 1975; Pitman and others, 1982; Keighin and Fouch, 1981; Fouch, 1985). 


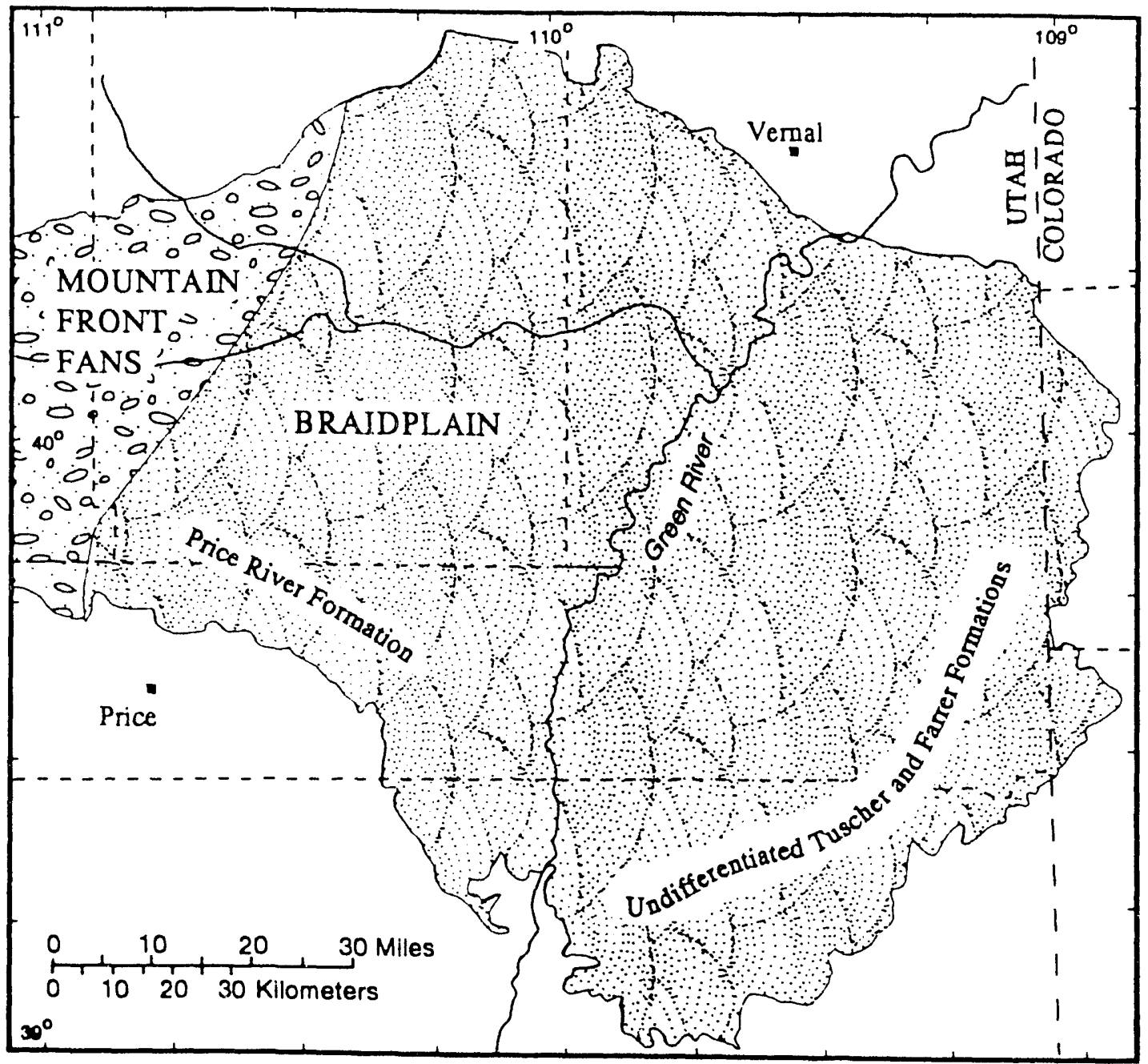

Figure 14 b. Paleogeographic map including Mesaverde Group depositional-facies at the time of the Campanian marine fossil zone of Baculites cuneatus and its nonmarine extensions (modified from Fouch and others, 1983). Rocks of the braidplain facies have yielded gas shows in tests along the southern margin of the basin and east of the Green River. Refer to figure 10 for the temporal position of the fossil zone. Much of this zone has been eroded from the top of the Mesaverde in part of the Uinta Basin. Less than 300 ft of younger Campanian and Maastrichtian rocks of the undifferentiated Price River. Tuscher and North Horn (Upper Cretaceous part) is preserved in some areas.

The sequence contains units with great contrast in ductility and as a results the reservoirs are commonly fractured in response to differential-brittle failure during periods of changes in stress. Fluvial channels developed in alluvial settings well outside the margin of the lake are intercalated with and encased within relatively ductile claystones. Brittle carbonate units are rare to absent. As a result, oil and associated gas have not migrated laterally through fractures from lacustrine source rocks into the fluvial-alluvial channels. However, in the southeast part of the basin, regional fractures locally penetrate Wasatch Formation fluvial-alluvial sandstones providing pathways for the vertical migration of nonassociated gas into Tertiary reservoirs from underlying Cretaceous source beds. .
The cyclic nature of the Tertiary units and the interbedding of mixed lake and alluvial rocks (Green River Formation) with red colored alluvial strata (Wasatch, Colton, and North Hom Formations) has resulted in some confusion in the appiication of stratigraphic names. Most formational names applied in the basin are representative of lithologic and depositional facies. As a result, several facies and formations can be preserved within a thin stratigraphic interval.

Figures 18, 19, and 20 illustrate the paleogeographic distribution of depositional facies for three periods of geologic time in the Paleogene. The maps characterize units within $100 \mathrm{ft}$ of strata approximated by the Paleocene lower marker of the Flagstaff Member of the Green River Formation, the PaleoceneEocene boundary, and the middle Eocene middle marker 


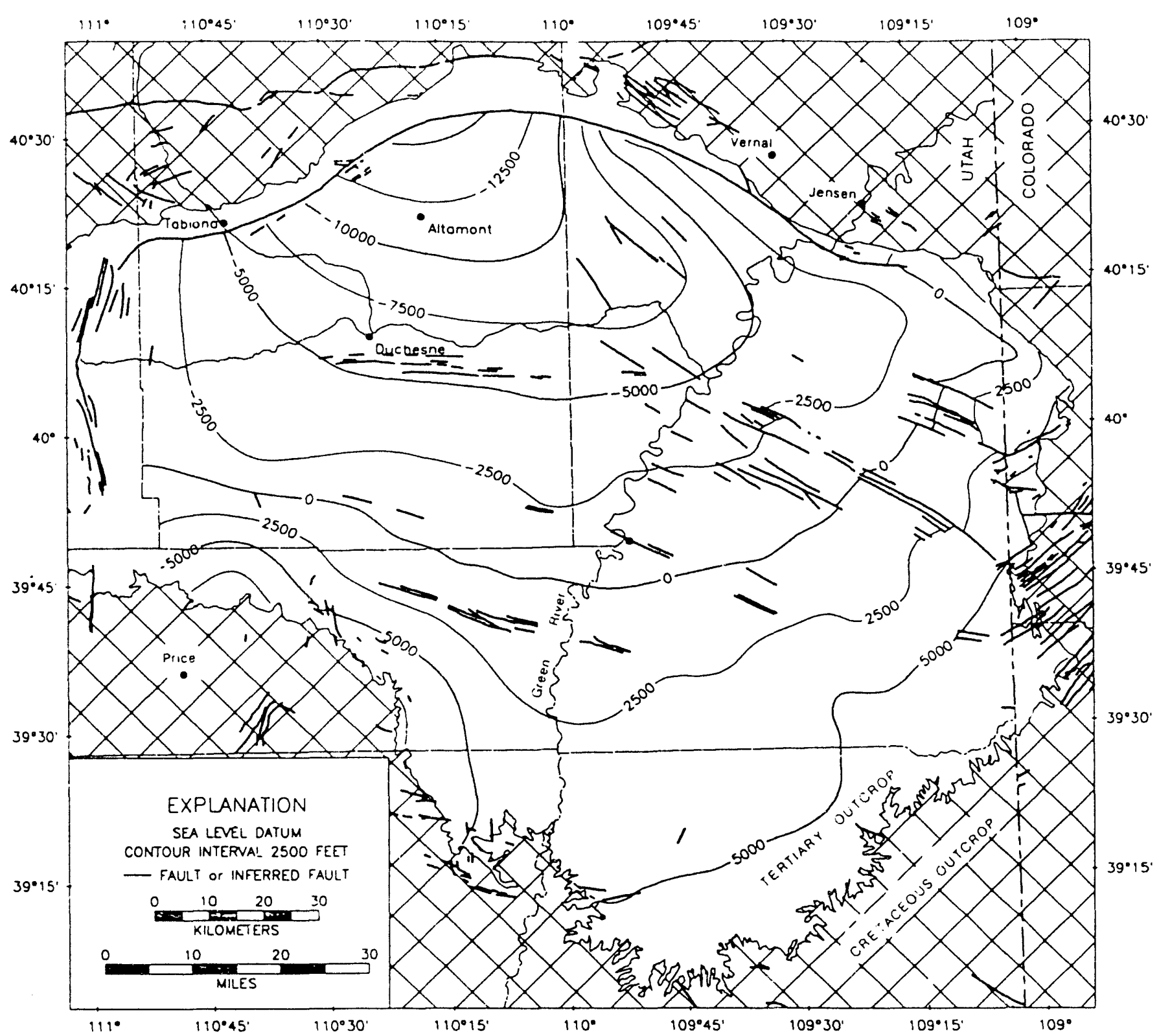

Figure 15. Structure contour map of the top of Upper Cretaceous strata (from Fouch and others, 1991). The westernmost part of the basin has been excluded from the map area where it intersects allochthons of thrusted strata.

of the Green River Formation as illustrated on figures 5,6 , and 7 . These markers can be traced from the surface throughout the subsurface of much of the basin (see Fouch, 1975; Ryder and others, 1976; Fouch and Cashion, 1979; and Fouch, 1981).

Lower marker rocks are the oldest Tertiary units in the basin that have yielded large volumes of oil or gas (fig. 18). Both are produced from the region of the Altamont-Bluebell producing area along the north margin of the former lake. In the southeast part of the Uinta, beds of this age onlap Cretaceous units along the northwest margin of the Uncomphagre structural element thus their limits and potential as gas reservoirs do not extend far east of the Green River (Fouch and Cashion, 1979; Stone, 1977). Oil and associated gas have been recovered from marginal-lacustrine rocks adjacent to the Paleocene-Eocene boundary (fig. 19). Like those of the lower marker, the distribution of potential reservoirs and beds of this age are limited where they pinchout against the Uncomphagre structural element a shor distance southeast of the presentday course of the Green River. Middle marker reservoirs yield large volumes of oil and gas at the extreme east end of the basin in Utah in the region of the Red Wash producing complex (fig. 2). In addition, strata of the middle marker zone and within a few hundred feet 


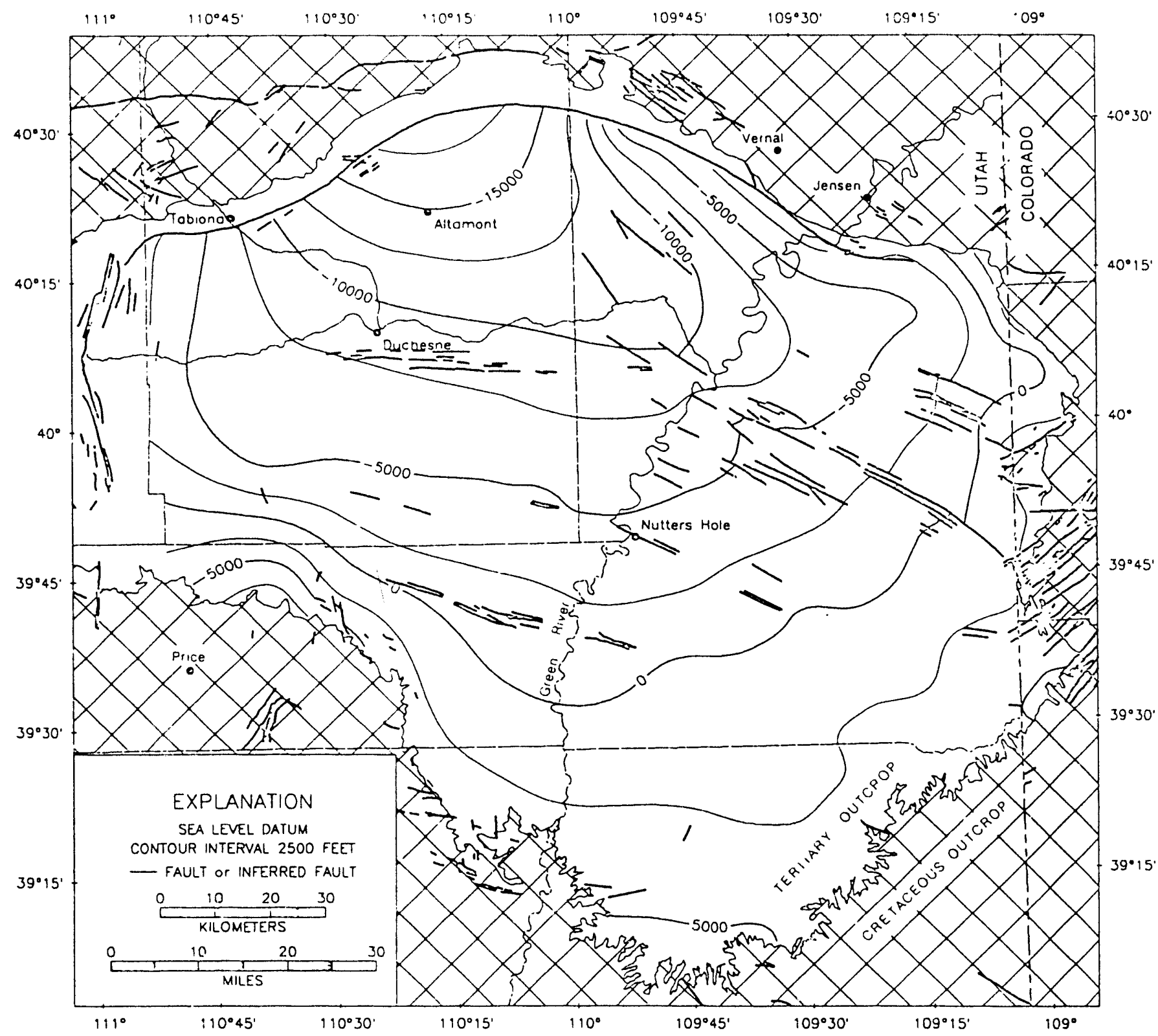

Figure 16. Structure contour map of the base of the Upper Cretaceous Mesaverde section that we are considering in this study (from Fouch and others, 1991). The map was constructed from interpretations of the base of the Blackhawk Formation or Star Point Sandstone of the Mesaverde Group, or the top of the Mancos Shale. These markers represent a westwarddownstepping set where each marker is progressively older. The sequence of reservoirs within the Mesaverde section is anticipated to contain the principal (Ipper Cretaceous gas-bearing units in much of the basin.

of it yield gas derived from the maturation of organic matter that accum.ulated in open-lake sites (fig. 20). Marginal-lacustrine units within this sequence contain gas in much of the eastern and northem parts of the basin. Beds from this stratigraphic sequence also contain tight alluvial sandstone reservoirs of the Wasatch and Colton Formations in the greater Natural Buttes producing area. In this region, the gas is believed to have been "erived from woody plant material in the underlying carbonaceous beds of the Mesaverde Group.

\section{Lithologic and Depositional Character of Productive Sequences}

\section{Red Wash, Altamont-Bluebell, and Pariette Bench Producing Areas}

Gas associated with oil is recovered from carbonate and sandstone reservoirs which are parts of green, gray and brown-colored lithologic s squences. Principal reservoir rocks are diagenetically altered fluvial channel, deltaic, and open lacustrine sandstones (in- 


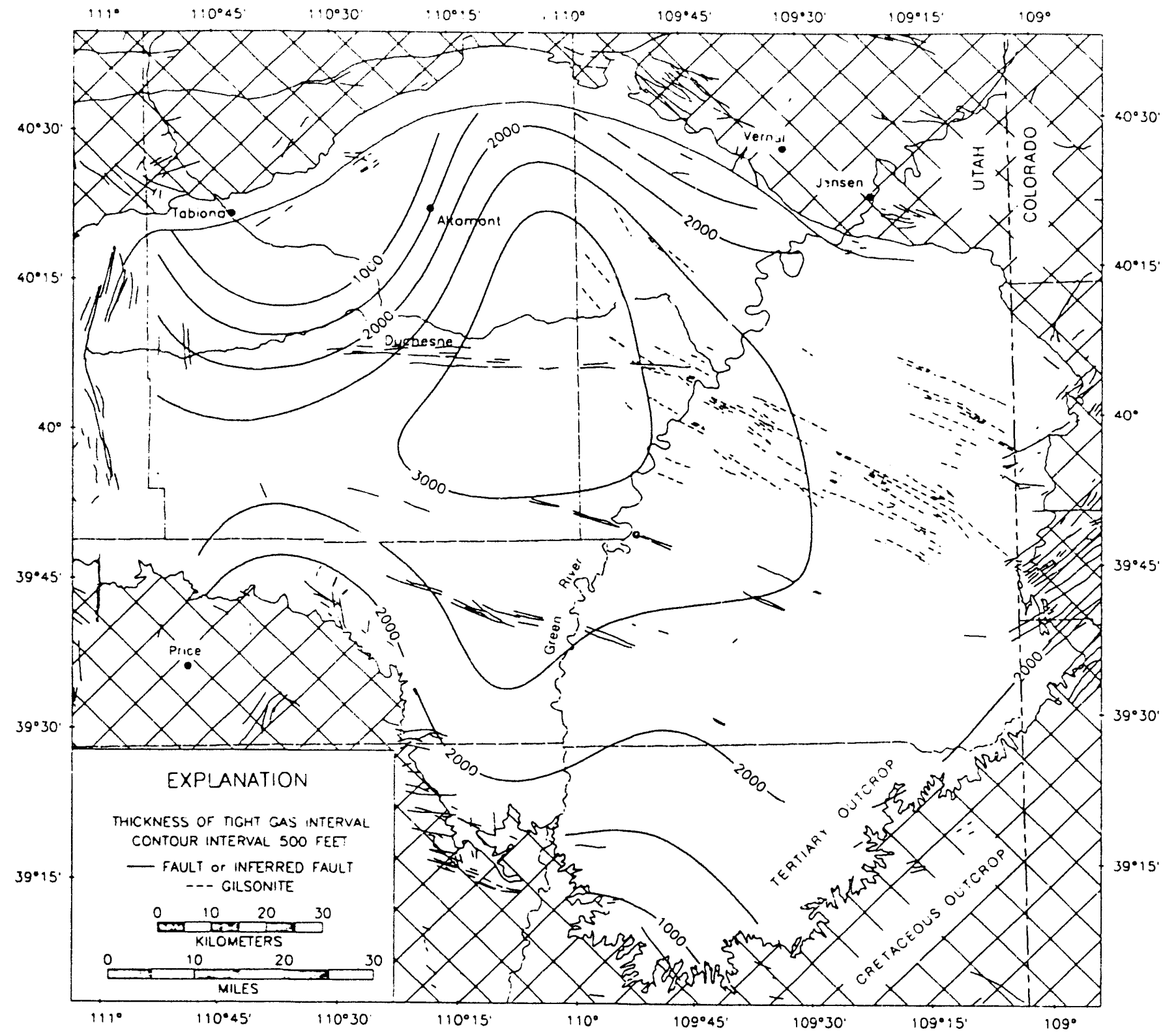

Figure 17. Preliminary isopach map of the Upper Cretaceous Mesaverde Group (from Fouch and others, 1991). The map excludes the westernmost part of the basin where thrusted allochthonous Cretaceous rocks are preserved, and it excludes Cretaceous and older beds north of the subsurface Basin Boundary fault. Map shows thickness and extent of section that contains potential impermeable gas reservoir units. In the study area, more than 70 percent of the Mesaverde section is composed of sandstone with the remaining portions being of mudrock, coal, and silt.

cluding turbidites in Altamont) that formed near the lake margin, and nearshore lacustrine bars and beaches that apparently developed parallel with the northeastem margin of the lake in Utah (figs. 21 and 22, and 23 a \& b). The fields in the region of the Red Wash, Altamont-Bluebell, and Pariette Bench producing complexes are examples of fields that contain large volumss of oil and associated gas (figs. $2 \& 7$ ). Mixed carbonate and clastic sequences are commonly assigned to the Green River Formation (Spieker, 1946; Fouch 1975, 1976, 1985; Johnson, 1985) (figs. 5 \& 6).
Virtually all of the oil and much of the associated gas recovered from these marginal-lacustrine reservoirs originated from the maturation of hydrogen-rich organic matter that accumulated on the lake floor.

\section{Natural Buttes Producing Area}

Nonassociated gas is recovered from clastic reservoirs (Wasatch, Colton, and much of North Hom Formations) that formed from sediment accumulated in alluvial settings well removed from the lake(s). 


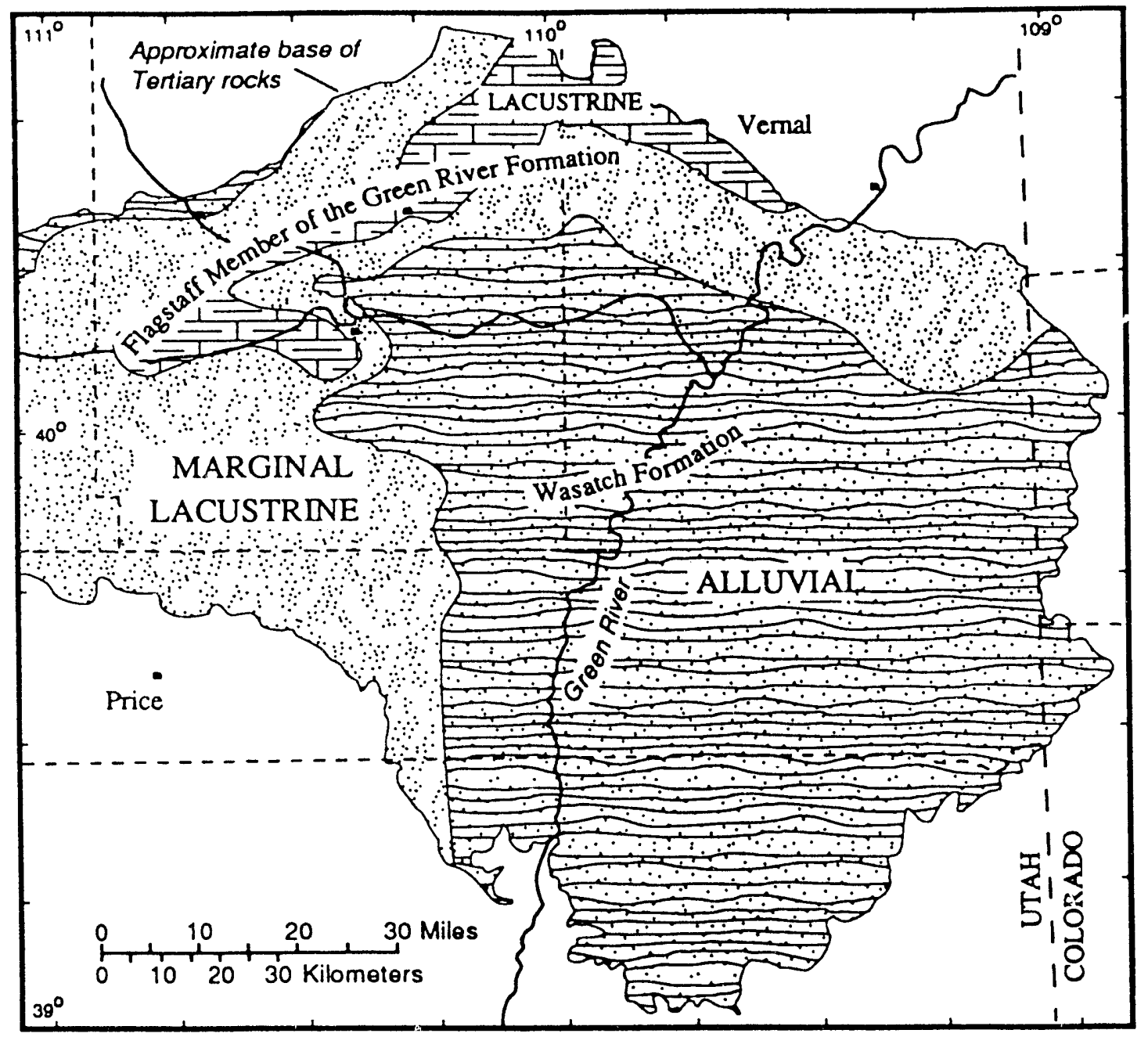

Figure 18. Paleogeographic map including depositional-facies of a zone consisting of beds adjacent and laterally equivalent to the lower marker of the Paleocene and Eocene Flagstaff Member of the Green River Formation (modified from Fouch. 1975). Oil and gas are produced the Altamont-Bluebell area along the north margin of the lake. In the southeast part of the Uinta Basin, beds of this age onlap Cretaceous units along the northwest margin of the Uncomphagre uplift thus limiting their potential as gas reservoirs east of the Green River (Fouch and Cashion, 1979; Stone. 1977). 'ee figure 3 for structural elements and figures 5, 6, and 7 for position of lower marker of the Green River Formation.

Although these rocks may be gas-bearing in the Uinta Basin, oil is sparse or absent from reservoirs formed in these more proximal environments. The area of Natu$\mathrm{ral}$ Buttes and Island gas fields is underlain by Tertiary rocks of the Wasatch Formation and they represent accumulations of gas in such a setting (fig. 24 a). These gas-bearing alluvial sequc.ces are commonly composed of variegated red and green sandstone and claystone units which form more than 95 percent of the sequence. The clastic strata represent the alluvial updip depositional equivalents of the oil-bearing mixed carbonate and clastic rock sequence that formed near the center of the lacustrine system. In the Uinta Basin, nonassociated gas in Tertiary rocks was derived from hydrogen-rich organic matter in both temporally equivalent lacustrine units of the Green River Formation and from oxygen-rich organic compounds in underlying strata of various origins in the Upper Cretaceous Mesaverde Group. Also, drill holes have penetrated gas-bearing rocks of the Mesaverde Group in the eastem part of the basin where they contain nonassociated gas that formed from the thermochemical transformation of organic matter within the Group (fig. 24 b \& c). 


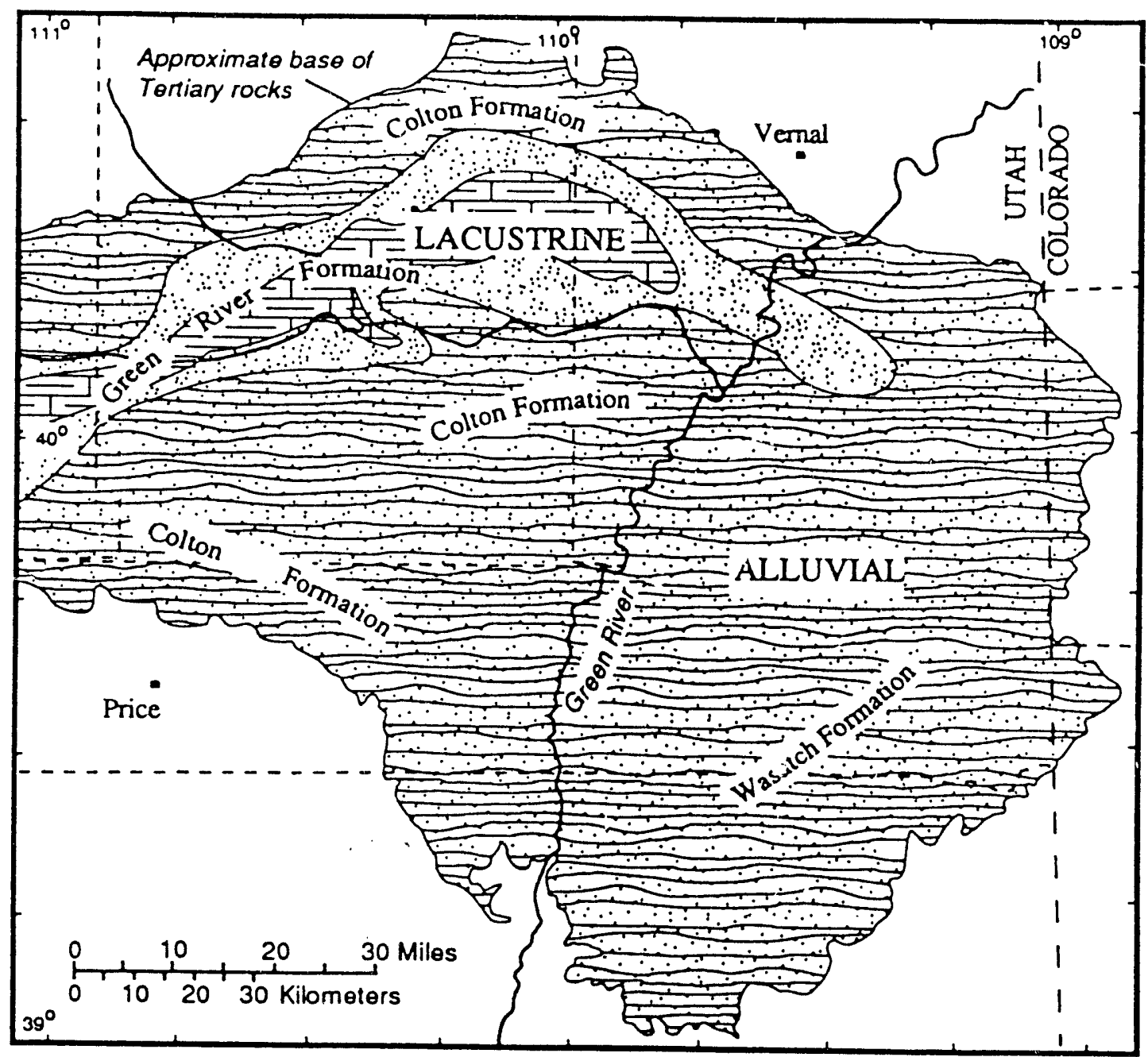

Figure 19. Paleogeographic map including depositional-facies in a zone consisting of beds adjacent and laterallyequivalent 10 the Paleocene-Eocene boundary (modified from Fouch. 1975). The distribution of potential reservoirs and beds of this age are limited where they pinchout against the Uncomphagre uplift a short distance southeast of the present-day course of the Green River. See figure 3 for structural features and figures 5, 6, and 7 for position of the Paleocene-Eocene boundary.

\section{DRILL-STEM TEST ANALYSIS AND FLUID-PRESSURE REGIME}

The productive oil and gas-bearing rocks can be divided into three groups of common reservoir character. Group 1 is composed of oil- and associated gasbearing deeply buried overpressured Tertiary rocks that are characterized by reservoirs whose in situ matrix permeability values are near, and are commonly below, $0.1 \mathrm{md}$ and whose porosity values (most porosity being secondary) average 5 percent, ranging from 3 to 10 percent. These strata contain open fractures and transmissivity ( $T=$ permeability $x$ height $)$ values through producing intervals that are commonly high. Group II rocks are characterized by combined primary and secondary porosity values of 10 to 16 percent in normally pressured Tertiary oil and associated gas reservoirs whose matrix permeability values may be as high as $1 \mathrm{~d}$. Transmissivity values for such sequences can be relatively high because of their high matrix permeability. Group III rocks include nonassociated gas in Tertiary and Cretaceous sandstone reservoirs that commonly contain porosity values ranging from 8 to 16 percent, but whose in sitt perme ability throughout the pay or gas producing section is $0.1 \mathrm{md}$ or less to gas (exclusive of fracture permeability) are classified as tight gas sandstones. Transmissivity values for productive "tight gas" intervals are very low because of relatively few natural open fractures.

Analysis of drill-stem test (DST) data from 78 tests in wells in Upper Cretaceous and lower Tertiary hydrocarbon-producing domains in the Uinta Basin indi- 


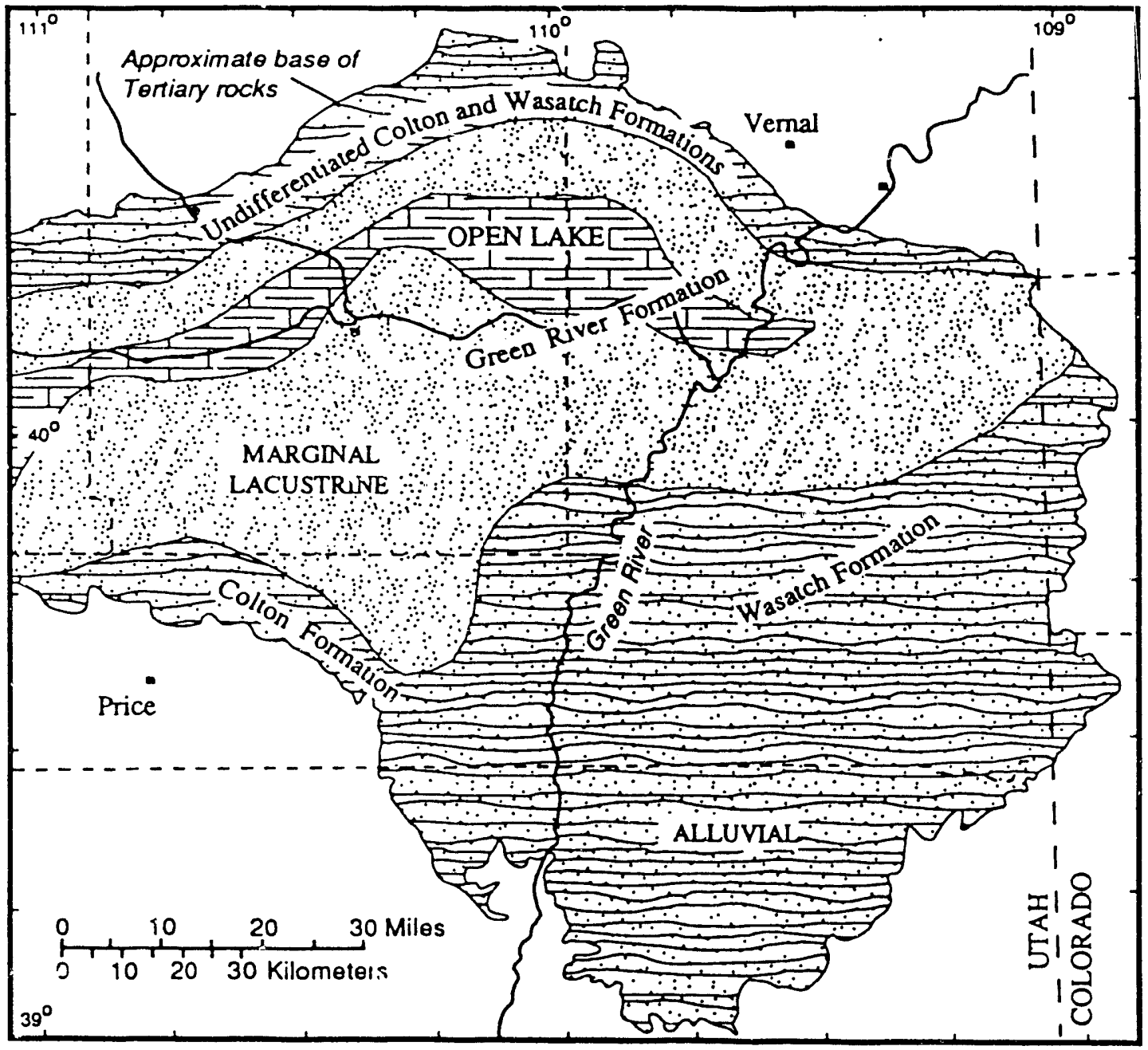

Figure 20. Paleogeographic map including depositional-facies in a zone consisting of beds adjacent and laterally equivalent to the middle marker of the Green River Formation (modified from Fouch, 1975). Middle marker reservoirs yield large volumes of oil and gas at the exrreme east end of the basin in the region of the Red Wash producing complex (fig. 2). Marginallacustrine units within this sequence contain gas in much of the eastern and northern parts of the basin. In addition, beds from this stratigraphic sequence contain tight alluvial sandstone reservoirs of the Wasatch and Colton Formations in the greater Natural Butes producing area. See figures 5, 6, and 7 for position of middle marker of the Green River Formation.

cates that natural fractures provide major conduits to move fluids and gases to the wellbore in otherwise very low-permeability strata (Wesley, 1990; Wesley and others, in press; Fouch and others, in press) (fig. 25). An evident lack of significant natural open fracture systems in impermeable Cretaceous and Tertiary producing intervals of the southeastem part of the Uinta Basin has resulted in relatively low producibility. Impermeable pay zones commonly require some type of artificial stimulation to increase gas flow to economic levels.

Many zones tested in deeply buried Group I rocks below depths of $10,000 \mathrm{ft}$ at Altamont-Biluebell oil field are fractured naturally. The permeability and radius of investigation in these rocks are relatively high, and the Homer-plot slope is low. Homer plots from DST's in Group II strata in and north of the large Red Wash field in the northeast Uinta Basin, especially for shallower alluvial rocks, exhibited low slopes associated with high permeability.

Most of our study relates to the evaluation of impermeable strata whose permeability values, exclusive of fracture permeability, generally fall below 0.1 millidarcy (md). Our DST determinations and interpretations of rock characteristics are consistent with the interpretations of Boardman and Knutson (1981) who investigated permeability structure of Uinta gasbearing units in the eastern part of the basin for both thick stratigraphic intervals and for short intervals at the scale of individual reservoirs. Our DST-derived 


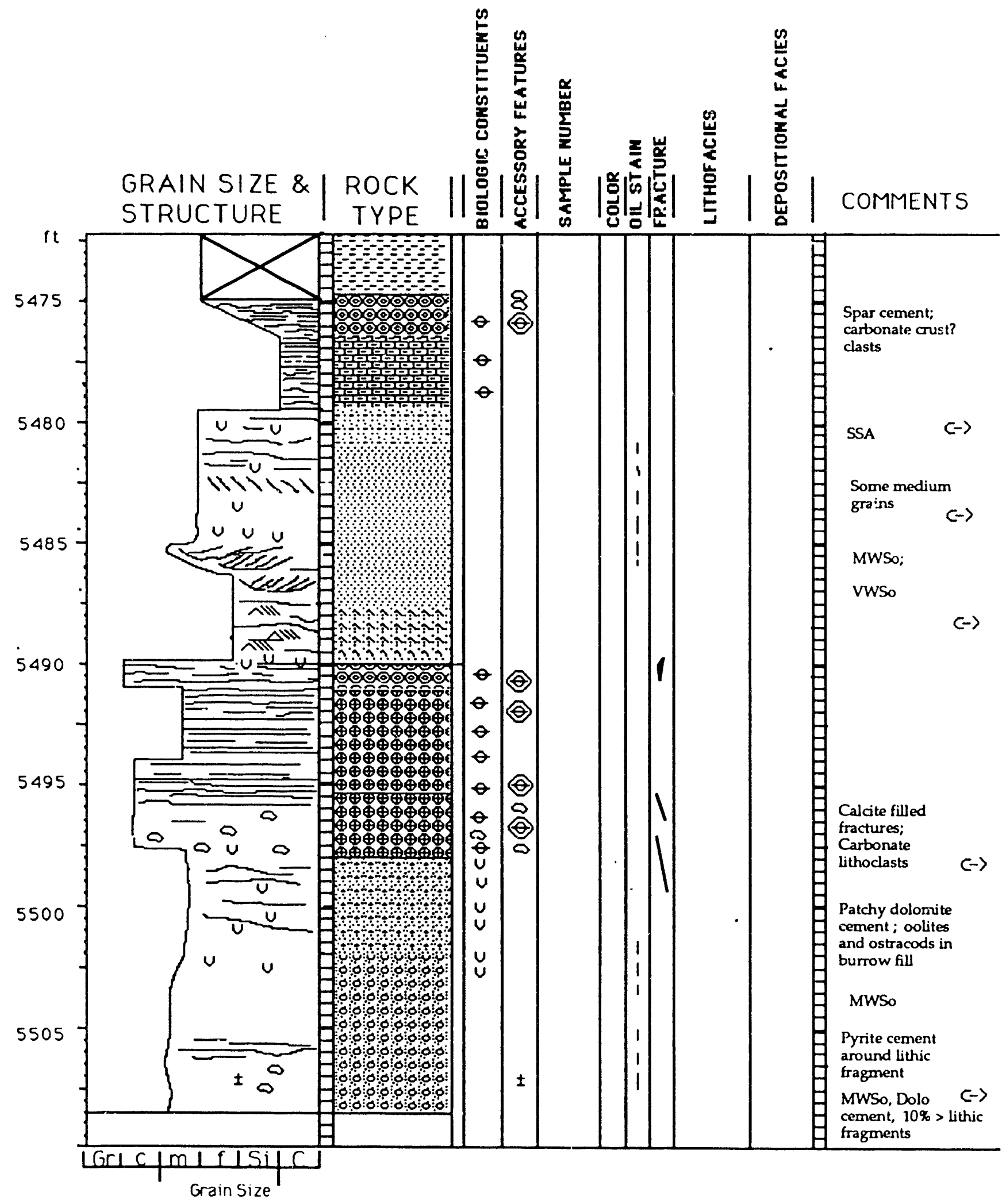

Figure 21. Lithologic and sedimentologic features of oil-bearing cored rocks in the Chevron Red Wash Unit 275, a well located in the central part of the Red Wash field, Utah. Strata depicted are of middle Eocene units of the Green River Formation. Oil-producing rocks are of a fluvial and lacustrine origin. Production is from fractured and unfractured rock. See figure 2 for location of Red Wash 
Pan American Broadhurst N0. 4 Sec. 9, T. 7S., R. $23 \mathrm{E}$.

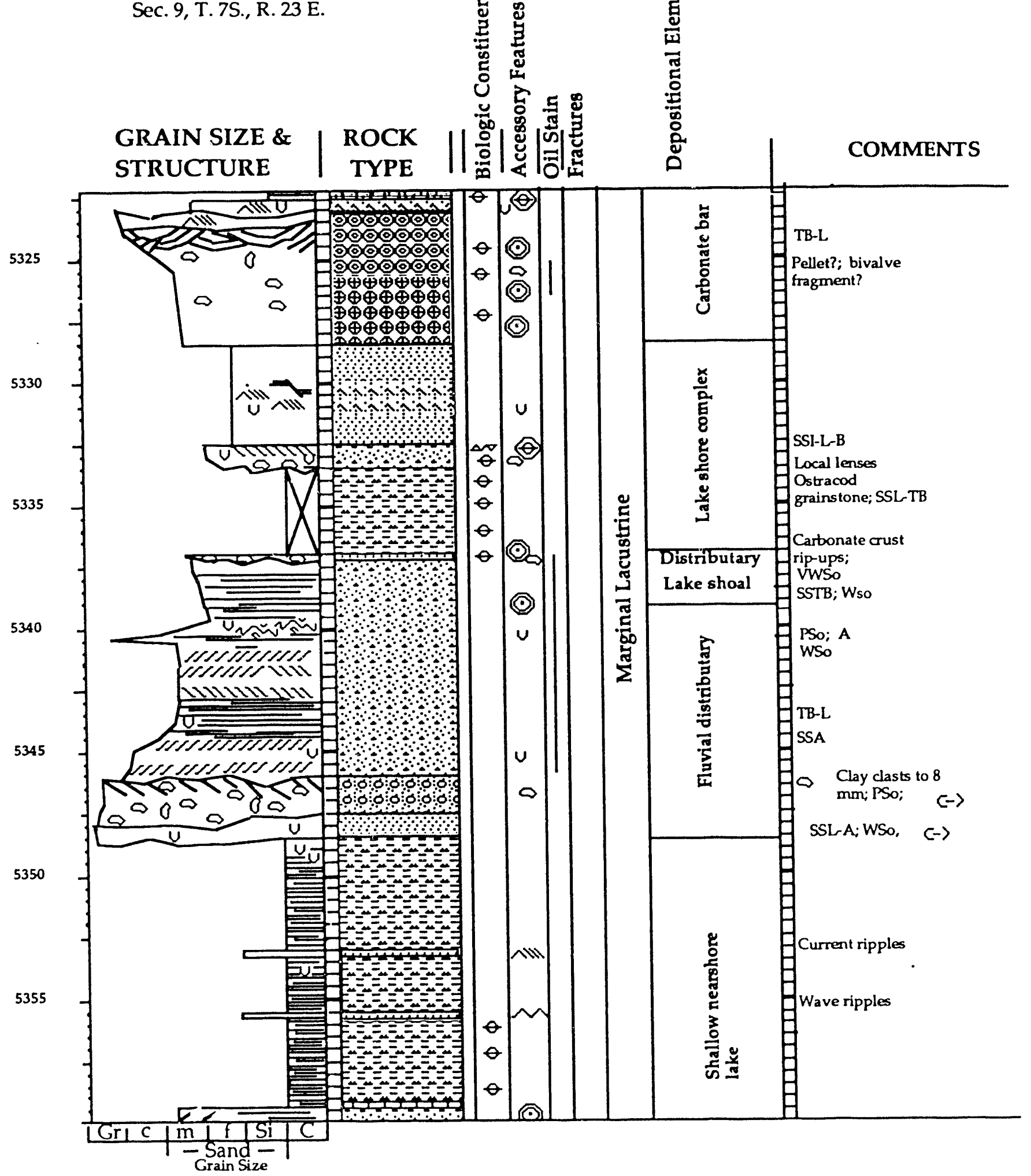

Figure 22. Lithologic and sedimentologic features of oil-bearing cored rocks in the Pan American Broadhurst No. 4, a well located at the northern margin of the Red Wash field. Utah. Strata depicted are dominantly of middle Eocene marginallacustrine fluvial rock of the Green River Formation. See figure 2 for location of Red Wash field. 


\section{EXPLANATION FOR FIGURES 21 AND 22}
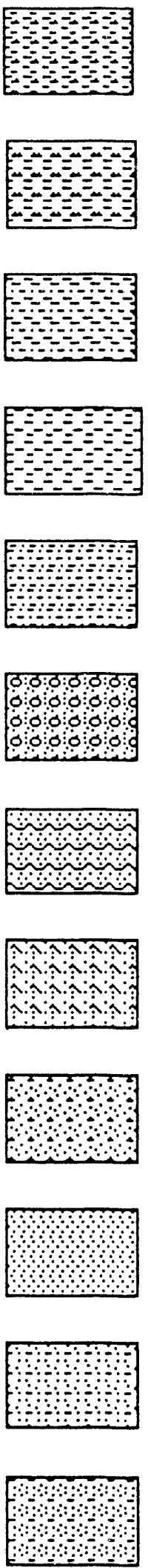

Claystone; dark grey to dark brown, slightly calcareous; thinly laminated to structureless; locally contains ostracode molds along laminae.

Claystone; dark grey to dark brown; moderately to very calcareous and is locally a argilaceous mud-supported carbonate rock; laminated to thinly bedded to structureless; locally very ostracodal.

Claystone; dark to medium gray to darker shades of brown; is locally calcareous and ostracodal; generally irrgeular to wavy laminae to thin bedded; locally contains sandstone and siltstone lenses.

Claystone; generally shades of gray and /or brown, locally gray green; noncalcareous to very slightly calcareous; generally indeterminately bedded to structureless to very thin bedded; blocky fracture.

Siltstone; generally shades of gray; grades locally to sandstone or claystone; irregular thin beds to laminae most common, laminae commonly marked with clay; usually calcareous to very calcareous;

Sandstone; generally calcareous; tan to light brown to gray,; commonly moderately well sorted but locally poorly sorted. Irregular thin beds to laminae and is locally structureless or laminated; Granules and pebbles most commonly of white, grey, and locally tan chert or other siliceous subrounded to angular lithic material.

Sandstone: generally calcareous; tan to light brown to gray; commonly well to very well sorted; symmetrical oscilation ripples common.

Sandstone; generally calcareous; tan to light brown to gray; commonly well to very well sorted; assymetric current ripples common.

Sandstone: commonly moderately calcareous; light brown to gray; generally well to very well sorted; structureless to very thinly la minated; ostracodes a re locally preserved.

Sandstone; noncalcareous to slightly calcareous; light brown or tan to darker shades of gray; structureless to thin bedded to laminated; sorting va riable; argilaceous streaks sparse but may be locally developed; fossils rare.

Sandstone; noncalcareous to slightly calcareous; light brown to tan to dark shades of gray; structureless to thin bedded to laminated; beds are irregular to even and continuous to discontinuous; silty streaks and silt and clay size matter common; ostracodes locally preserved along clay laminae.

Sandstone; noncalcareous to very calcareous; generally darker shades of gray and brown; structureless to laminated and beds discontinuous and irregular to continuous and even; clayey and silty streaks locally common; ostracode molds are locally common along clay laminae. 


\section{EXPLANATION FOR FIGURES 21 AND 22 (continued)}

Grainstone and/or packstone; ostracodal, locally contains coated grains; generally light brown to tan, some units are dark brown, kerogenous and argillaceous; structureless to laminated; laminated units commonly are rich in clay;

Grainstone and/or packstone; contains coated grains, oolites, and/or pisoliths; coatings commonly developed on ostracod tests; generally light to dark shades of brown; local spar carbonate cement; commonly structureless to faintly thin bedded to laminated; locally argillaceous;

Carbonate mudstone and/or wackestone; locally contains abundant ostracod tests and molds along laminae; light to dark brown. locally tan; generally thin bedded to laminated, irregular to even bedded;

Carbonate mudstone and/or wackestone; generally clayey and kerogenous, and is locally a clay mudstone; ostracod tests and molds are locally common; fossiliferous rock is commonly laminated but structureless fossiliferous and nonfossiliferous units are common;

Carbonate mudstone and/or wackestone; commonly quite clayey, kerogenous, and sandy; rock is locally a very calcareous sandstone or cluyey siltstone and contains thin lenses of these lithologies; rocks are generally darker shades of brown but is locally dark grey; bedding is commonly irregular and discontinuous;

Carbonate mudstone and/or wackestone; ostracod tests and molds common; commonly sandy and local sandstone lenses; some units are clayey; bedding is generally laminated to structureless and ranges from irregular to even;

\section{Rock Color}

B

$\mathrm{dg}$

$\lg$

bl

ggn

ogr

gr

rgr

r

bu

$\mathrm{lb}$

$\mathrm{mb}$

$\mathrm{db}$

$\int^{d b}$

Grey

Dark Grey

Light Gray

Black

Gray green

Olive green

Green

Red and green, mouled

Red

Buff/tan

Light brown

Medium brown

Dark brown

Dark brown grading to red 


\title{
EXPLANATION FOR FIGURES 21 AND 22 (continued)
}

\author{
$\pm$ \\ Pyrite or marcasite \\ - Calcareous; moderately to highly \\ - Calcareous; slightly to moderately \\ $0->\quad$ Grains rounded to subangular \\ 0-) Grains rounded to subrounded \\ $\Leftrightarrow \quad$ Grains subrounded to subangular \\ $\begin{array}{ll}\text { Lo } & \text { Lithoclasts; generally composed of indigenous carbonate rock type; commonly a }\end{array}$ \\ Granules and pebbles composed of siliceous rock types; commonly tan to light grey \\ cher, locally are of silicified sedimentary rock. \\ ? Uncertain identification \\ $\checkmark \quad$ Burrow; vertical or at high angle to bedding \\ c Burrow or track; horizontal or at low angle to bedding \\ (9) Coated ostracode; some grains have several coats. \\ $\theta \quad$ Ostracode test or mold \\ (.) Coated grain, pisolite, and/or oolite \\ G Gastropod \\ $\phi \quad$ Fossil; undifferentiated type \\ Plant material; generally very small fragments or impressions, and/or carbonaceous
matter \\ Woody fragment \\ A Root bioturbation \\ $\equiv \quad$ Laminated to very thinly bedded; continuous to discontinuous \\ Aill Ripples; current lamination \\ Sิ: Contorted beds or laminae; local dewatering and/or sediment ioading \\ LIS \\ Cross stratification: generally small to medium scale and \\ unidirectional
}




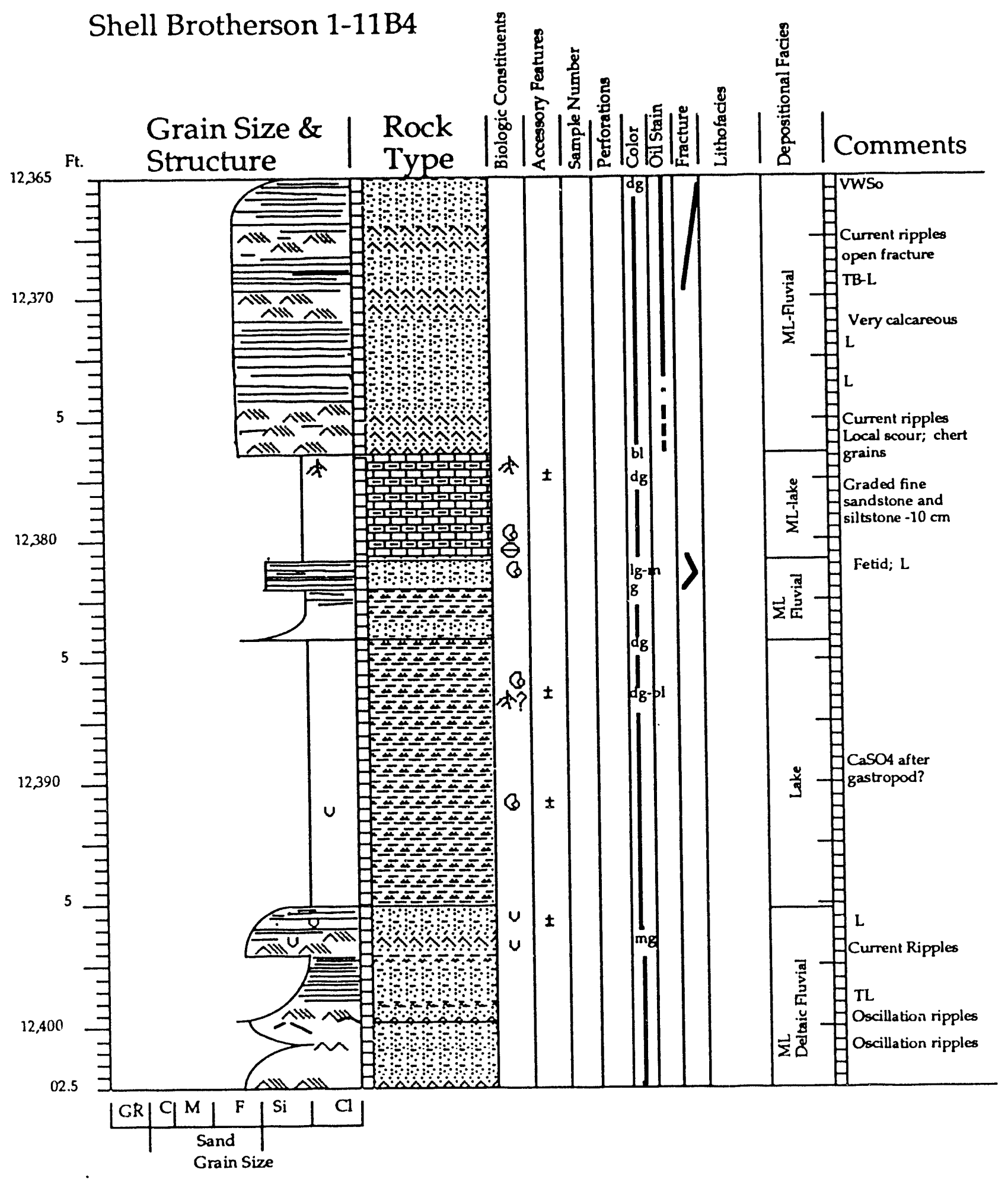

Figure 23 a. Lithologic and sedimentologic features of oil-bearing cored rocks extending from 12.365 $1012,402.5$ ft. Shell Brotherson 1-11B4, central part of the Altamont-Bluebell field, Utah (fig. 2). Strata depicted are lower Eocene units that lie at or near the boundary between the Paleocene and Eocene units of the Green River Formation (seefig. 5). Oil-producing rocks are of a fluvial and lacustrine origin. See figure 5 for stratigraphic placement. 


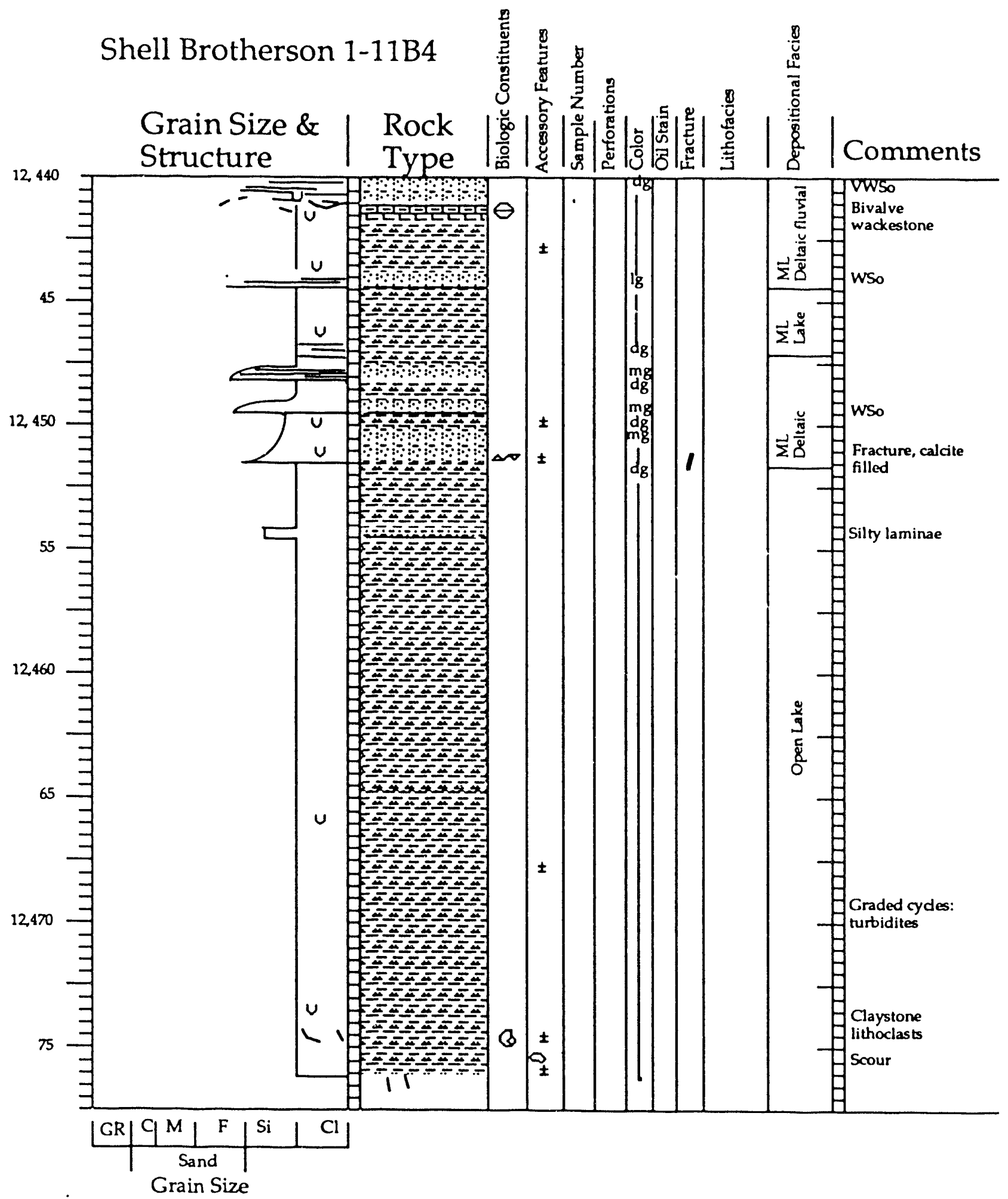

Figure $23 \mathrm{~b}$. Lithologic and sedimentologic features of oil-bearing cored rocks extending from 12,440 to $12,477 \mathrm{ft}$. Shell Brotherson 1-11B4, central part of the Altamont-Bluebell field, Utah (fig.2). Strata depicted are lower Eocene units that lie at or near the boundary between the Paleocene and Eocene units of the Green River Formation (see fig. 5). Oil-nroducing rocks are of both a fluvial and lacustrine origin. See figure 5 for stratigraphic placement. 


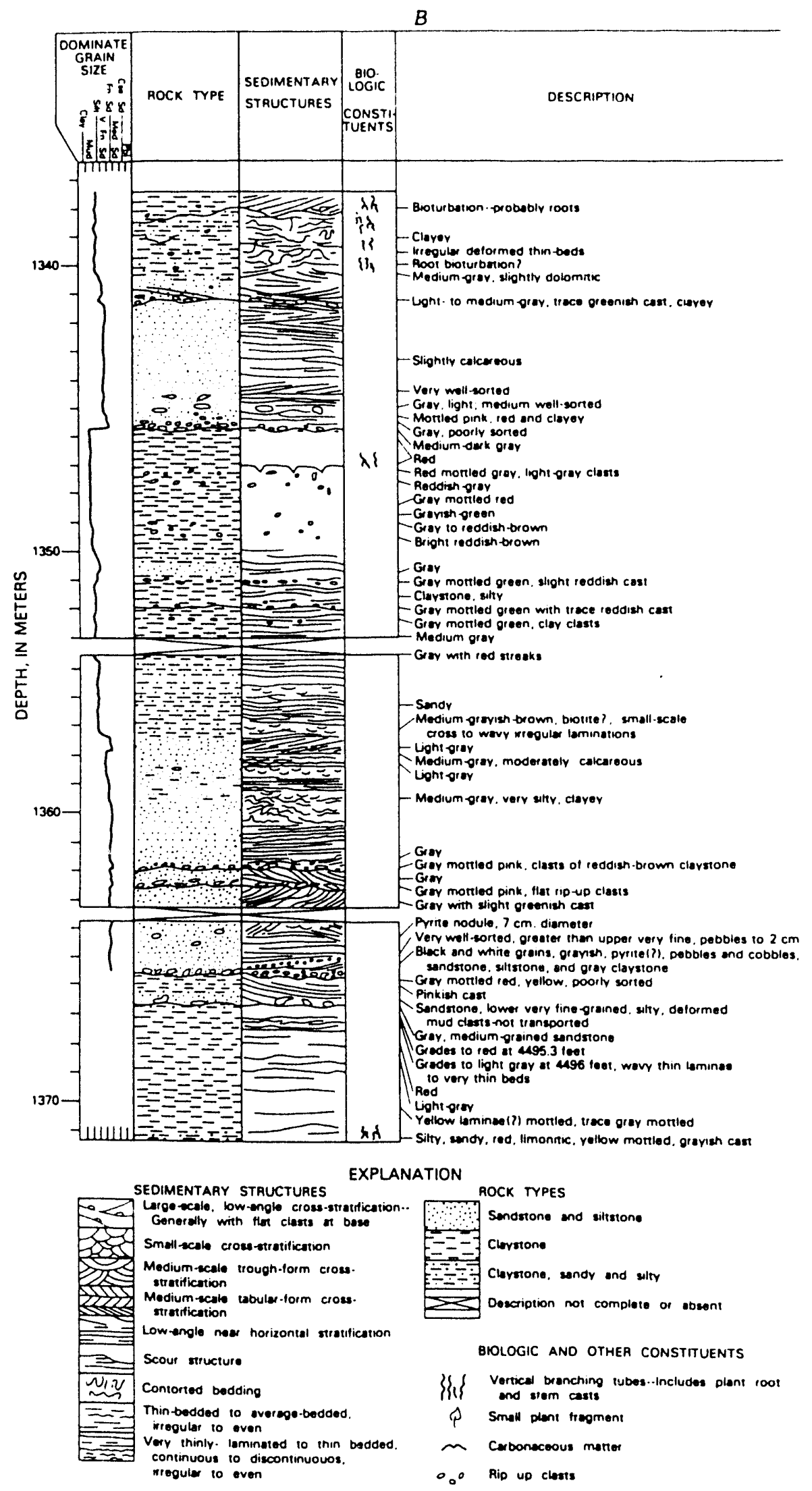

Figure 24 a. Lithologic and sedimentologic features of cored lower Tertiary Wasatch Formation rocks in the CIGE Natural Buttes No 21-15-22, NW 114, Sec. 15, T.15S, R.22E, Natural Buttes field, Utah (fig. 2). Gas is recovered from Wasatch Formation sandstone reservoirs in thisfield. Reservoirs are in approximately the same stratigraphic position as those shown in the Island field on figure 6. See figure 7 for the projection of the gas-bearing interval at Natural Buttes to cross section $A-A^{\prime}$. 


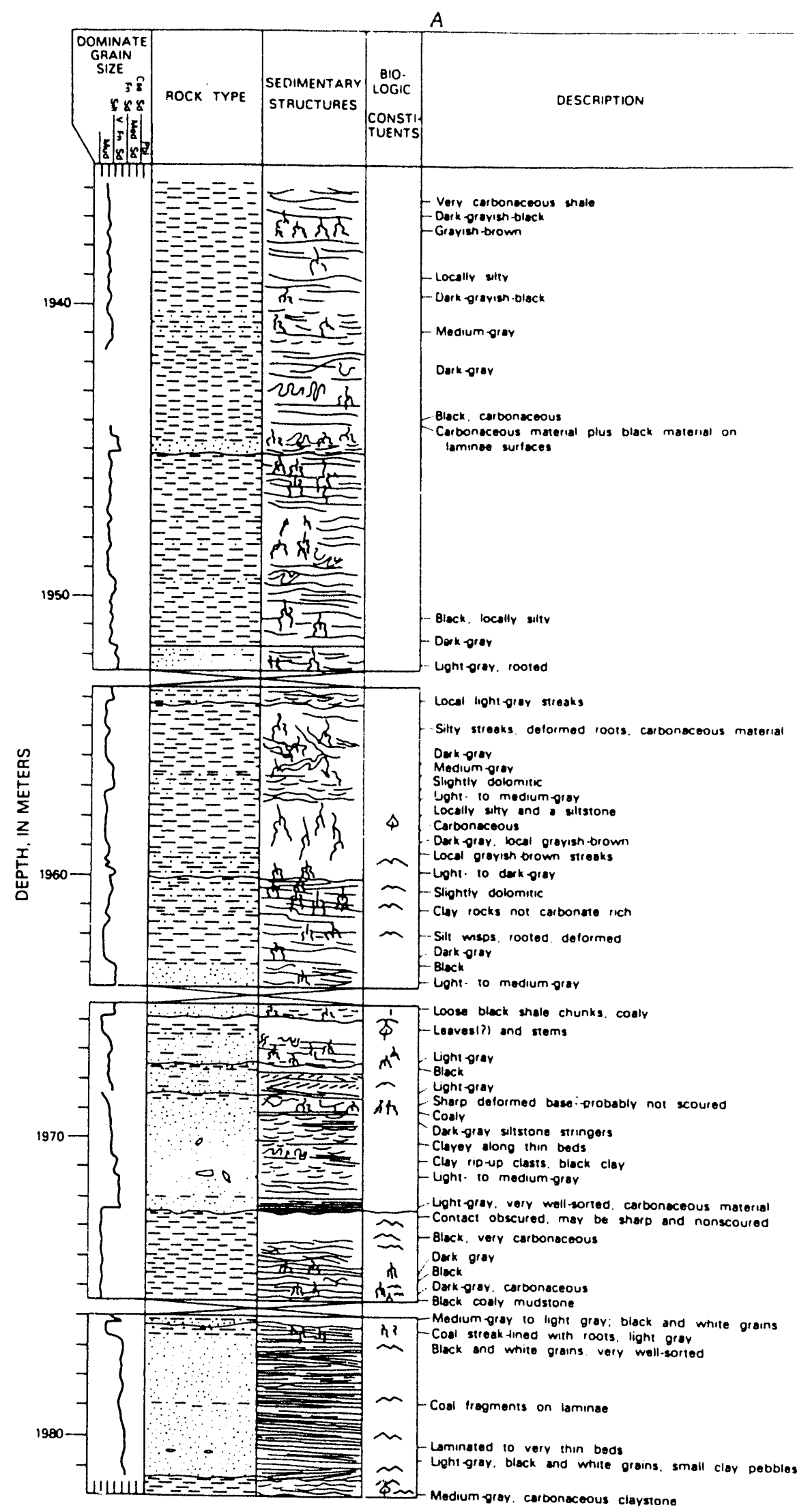

Figure $24 \mathrm{~b}$. Lithologic and sedimentologic features of Upper Cretaceous $T$ uscher Formation of the Mesaverde Group cored rocks from the CIGE Natural Buttes No 21-15-22, NW 1/4, Sec. 15, T15S, R22E, Natural Buttes field, Utah (fig. 2). Strata depicted are of the. See figure 7 for the projection of the gas-bearing interval in Natural Buttes to cross section A-A'. 


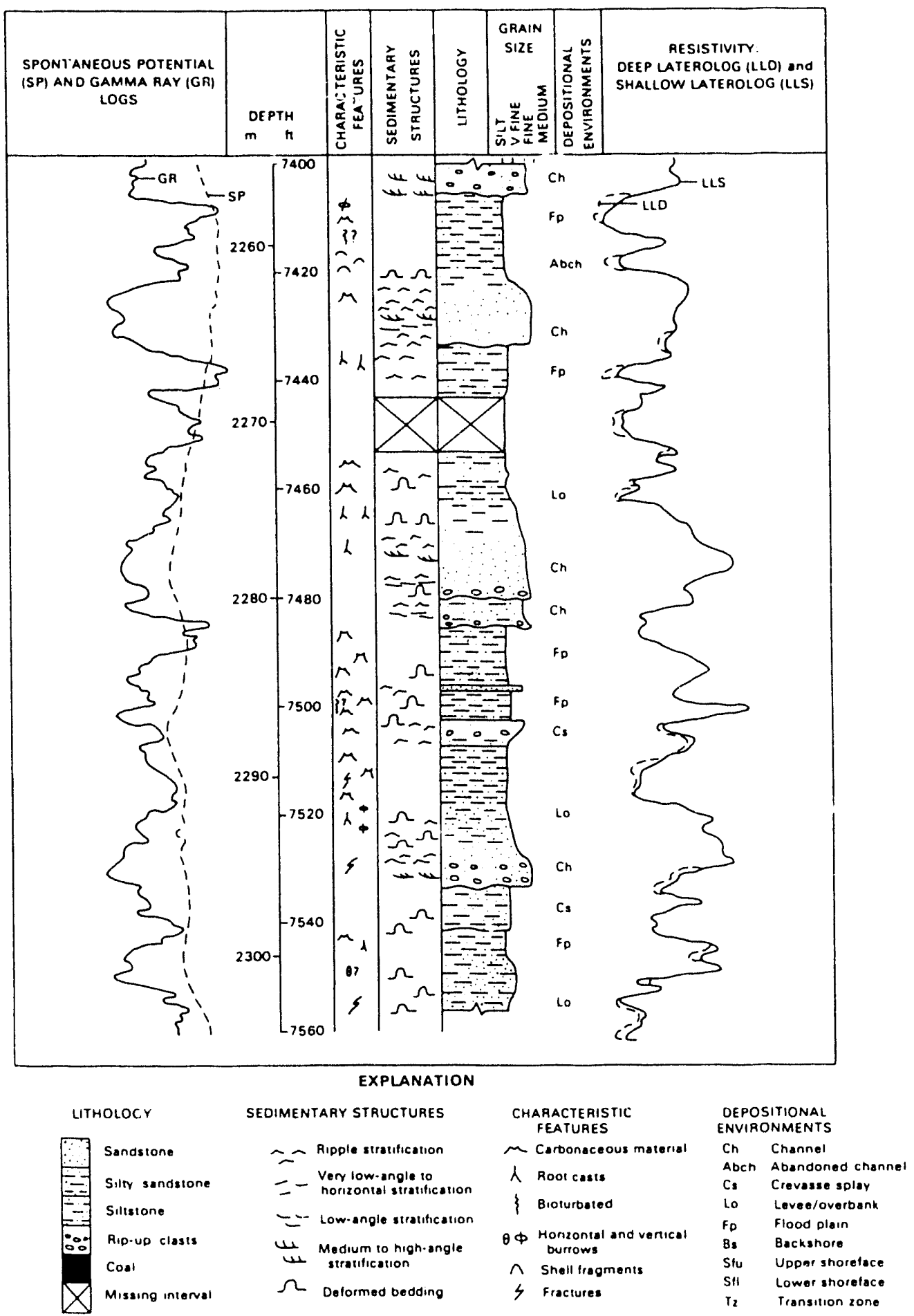

Figure $24 \mathrm{c}$. Lithologic sequences and geophysical log responses for cored units of the Blackhawk Formation of the Upper Cretaceous Mesaverde Group in the CIGE Natural Buttes No 21-15-22, NW 1/4. Sec. 15. T15S, R22E. Natural Buttes field. Utah (fig. 2). Figure is from Pitman, Franczyk, and Anders, 1987. 


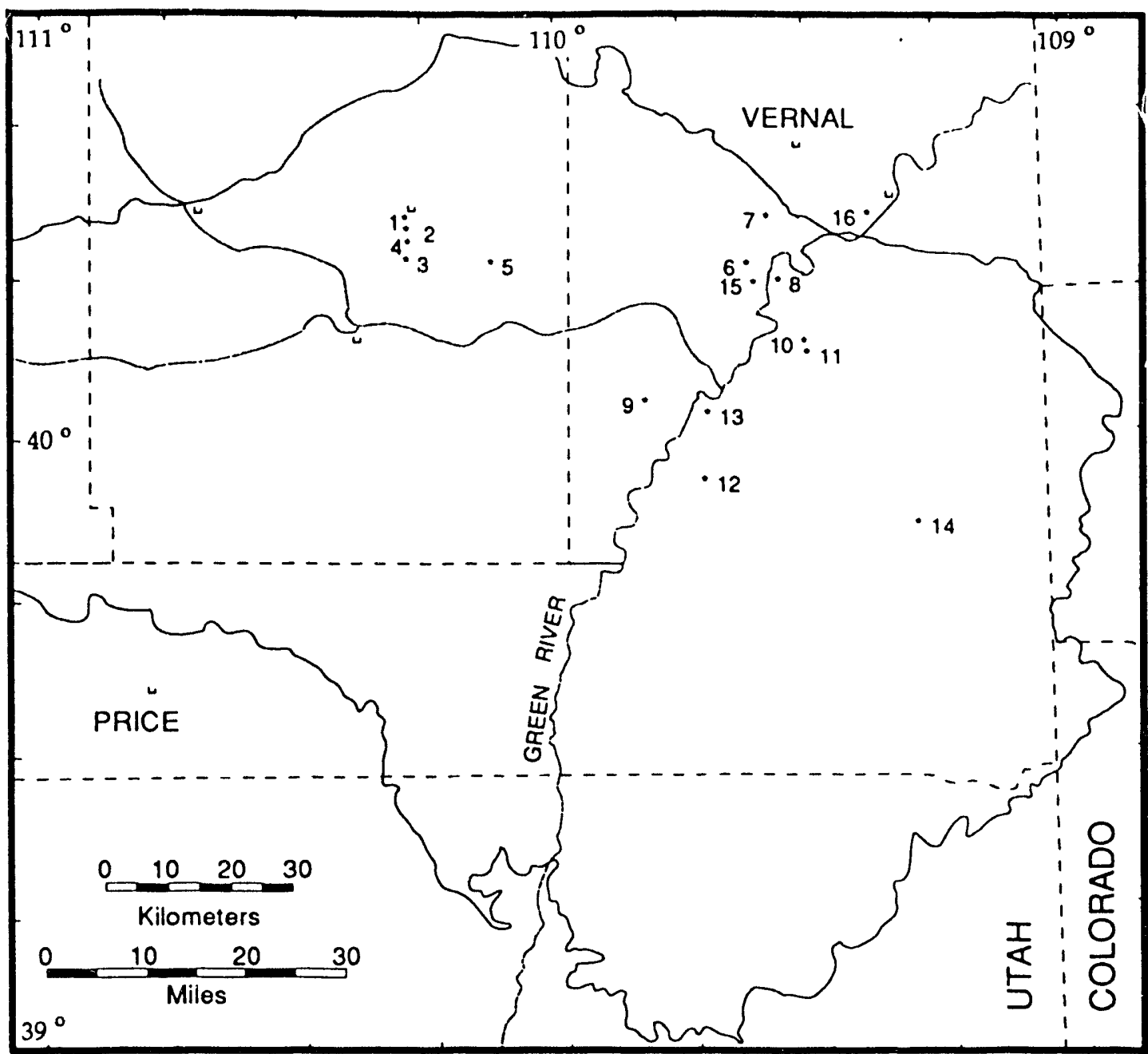

1 - 1 Miles, Shell Oil

2 - 1-3 Shell-Tenneco-E, Shell Oil

3 - 1-14-B4 Shell Brotherson, Shell Oil

4 - 1-11-B4 Brotherson, Shell Oil

5 - 1-16 Gulf-Ute, Diamond Shamrock

6-1 Government, Gose Petroleum

7 - 1 Govt.-Dicarlo, King-Stevenson

8- 1 Rowe-Govt., McLish H. P.

9-6 Pariette Bench, Pan American Petroleum

10 - 2 Wonsits-Federal, Gulf Oil

11 - 5 Federal-Wonsits Unit, Gulf Oil

12 - 3 Island Unit, Mountain Fuel Supply

13 - 1 River Junction, Phillips Petrolcum

14 - 7 Southman Canyon, Shell Oil

15 - 1 Gose-Government, McLish H. P. Etal

16 - 1 Stewart-Fee, Walton Paul T.

Figure 25. Map of the Uinta Basin. Utah showing location of drill holes that contain drill stem tests analyzed in this report. 
permeability values for thick stratigraphic intervals of Group III impermeable gas-bearing strata in the southeastem part of the basin are very similar to permeability values derived from individual core samples (sce Wesley, Wandrey, and Fouch, 1991). This is presumably due to the encasement of numerous individual Wasatch Formation reservoirs in relatively ductile claystone and the lack of numerous continuous open natural fractures in tight-gas formations in the eastem part of the basin which, if present, would most likely provide larger scale, higher permeability flow conduits.

Deeply buried Group I overpressured strata are characterized by reservoirs whose core-derived in situ matrix permeability values are near, and commonly below, $0.1 \mathrm{md}$ and whose porosity values (most porosity being secondary) average 5 percent and range from 3 to 10 percent (Figs. 26 and 27). These strata contain open fractures and therefore transmissivity $(T=$ permeability $x$ height) values through producing intervals are commonly high. In this basin, combined primary and secondary porosity values of 10 to 16 percent are common in normally pressured Group II oil and gas reservoirs and matrix permeability values may be as high as I d. As a result, even though these rocks contain relatively few open fractures, transmissivity values for such sequences can be relatively high because of their high matrix permeability.

It is important to note that the subsurface temperatures calculated from DST analyses (Wesley ,1990; Wesley, Wandrey, and Fouch, in press) show that in the Altamont-Bluebell area, temperatures at drilling depths near $14,500 \mathrm{ft}$ in Tertiary strata are currently near $270^{\circ}$ $F$ and that underlying Mesaverde Group rocks are hotter. Information presented in a later section of this report indicates that organic matter in rocks at these temperatures would be transformed into oil and/or gas.

Known gas-bearing sandstone reservoirs in the basin that commonly contain porosity values ranging from 8 to 16 percent, but whose matrix and formation permeability values are $0.1 \mathrm{md}$ or less are "tight gas" sandstones. Transmissivity values for existing productive "tight gas" intervals are very low because of few natural open fractures.

Our analysis of drill-stem tests also included determination of fluid-pressure gradients. Such gradients can be estimated using a variety of techniques including comparison of mud weights versus drilling depths. Our analysis was restricted to the calculation of gradients using extrapolated shut-in pressures for those DSTs in our sample that were of long duration (see
Wesley, 1990; Wesley, Wandrey and Fouch,. 1991). Figure 26 is a map of the DST-derived fluid-pressure gradients and Figure 27 is a cross section of the basin illustrating that portion of the subsurface for which fluid-pressure gradients exceed $0.5 \mathrm{psi} / \mathrm{ft}$. Temperatures near $14,500 \mathrm{ft}$ in the well on the left side of figure 27 are near $270^{\circ} \mathrm{F}$. Note that our analysis indicates that the measured abnormally high gradients are restricted to Tertiary rocks. Our determinations largely agree with the map view of the pressures presented in Lucas and Drexler (1976), and in Spencer (1987, fig. 15); and they concur with the cross-sectional view of pressures of Fouch (1975, fig. 2).

We suggest for reasons discussed later in this paper that the highest fluid-pressure gradients are located in that part of the subsurface where impermeable rocks, exceptionally rich in hydrogen-rich organic matter, have been subjected to sufficient heat to transform thermochemically their organic matter into petroleumlike compounds at such a rate, and in such volume that the increase in volume of petroleum has effected an increase in fluid-pressure gradients. Figure 27 indicates that fluid-pressure gradients in decply buried strata decrease in the North Hom Formation, a unit not particularly rich in hydrogen-rich type I organic matter in that area. Fluid-pressure gradients decrease in rocks where pressures have equilibrated to normal hydrostatic gradients. In these rocks, the rate of hydrocarbon and other fluid production, in the zone of thermal generation, is less than the rate of migration through permeablity pathways (fracture permeability).

Data from Lucas and Drexler (1976), and from unpublished studies of core by us, suggest that open fractures are much more common within the overpressured strata than without. This relation of abnormally high fluid-pressure gradients, rich source rocks, maturation temperatures, and open fractures suggests that the fractures may be the result of the rapid and ongoing generation of hydrocarbons within the largely impermeable subsurface rock cell. Spencer used analysis of mud weights to conclude that Cretaceous units in a well in the southwest part of the basin achieved nuidpicssure gradients as high as $0.6 \mathrm{psi} / \mathrm{ft}$ and that a mudweight equivalent to $0.8 \mathrm{psi} / \mathrm{ft}$ was used to control the well at drilling depths of $19,000 \mathrm{ft}$. Likewise, although as yet untested in the structurally lowest (and hottest) part of the basin, organically-enriched units of the Mesaverde Group that are encased in impermeable strata can be expected to be overpressured, and if so, they can be expected to contain some natural open fractures. 


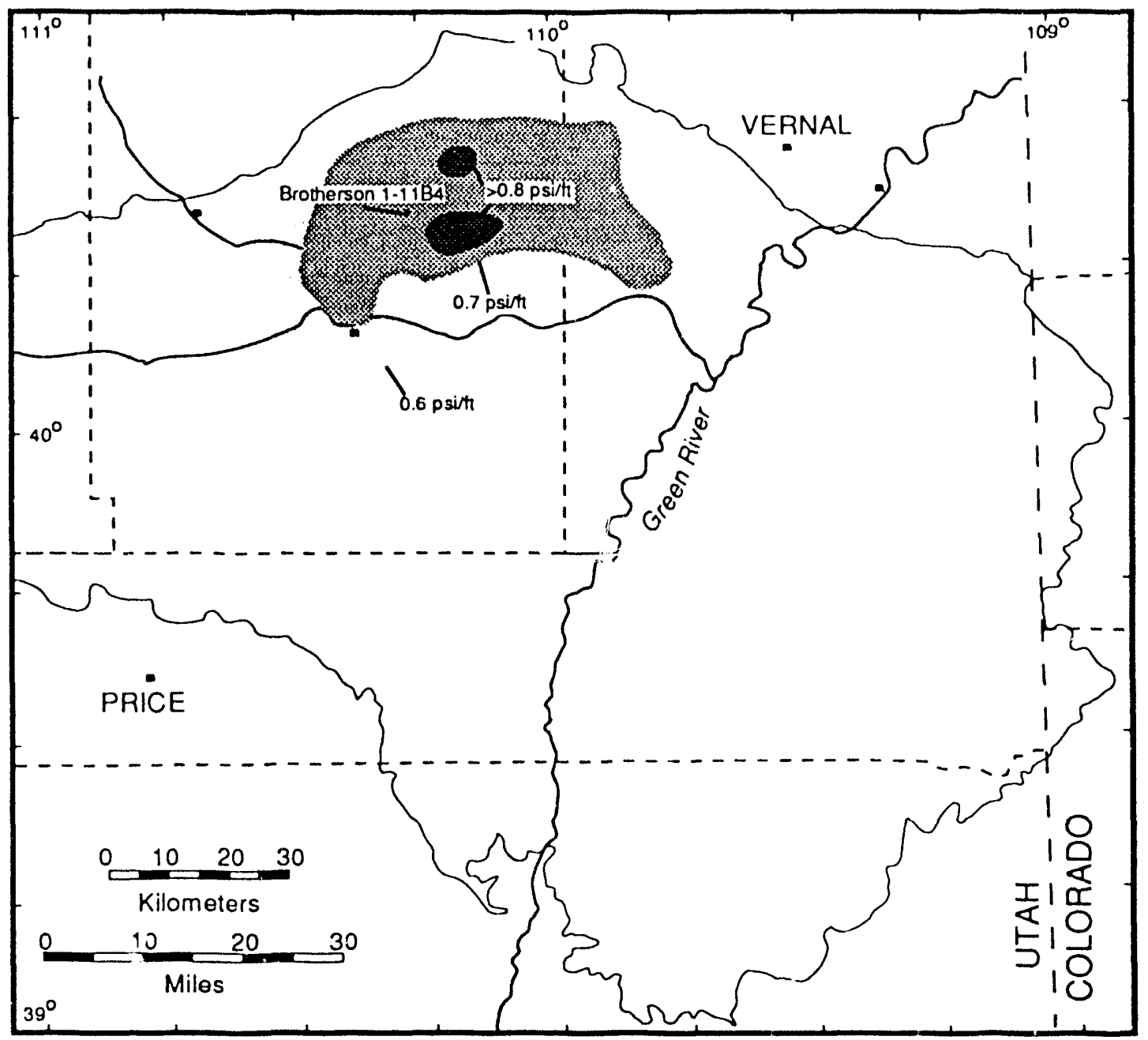

Figure 26. Map of maximum fluid pressure gradients 0.6 psi and above for Tertiary strata in the Uinta Basin (also modified from Fouch. 1975; Lucas and Drexler, 1976; Wesley, 1990; and Spencer 1987). Map is based upon interpretations of drillstem tests although interpretations of mud weights may indicate additionsl strata with abnormally high (or low) fluid pressures. Contour interval is 0.1 psifft. Maximum values occur in various stratigraphic intervals (see figs. 27 and 32 following). Fluid-pressure gradients of Upper Cretaceous strata in the north-central part of the basin have been measured by one drill-stem test (Shell, Brotherson 1-11B4, sec. 11,T. 2 S., R. 4 W.).

\section{THERMAL HISTORY OF ORGANIC MATTER}

One of the most important factors controlling petroleum generation in a basin is the level of thermal maturity achieved by the source rocks. Of equal importance to the geological characterization of the Uinta Basin, thermal maturity studies play an important role in determining sandstone diagenesis patterns, timing of structural movement and burial reconstruction, and prediction of porosity trends for reservoir rocks. For this study, thermal maturity was determined by vitrinite reflectance $\left(R_{m}\right)$, coal-rank data, and Tmax from Rock-Eval pyrolysis (table 1). Most of the data used to construct the maps were taken from Nuccio and
Johnson (1986), Nuccio and Johnson (1988) and V.F. Nuccio, U.S. Geological Survey, unpublished data. Three maturity maps showing important gas generation thresholds were developed: (1) an $\mathrm{R}_{\mathrm{m}}$ map of the base of the Upper Cretaceous Mesaverde Group; (2) an $\mathrm{R}_{\mathrm{m}}$ map of the top of the Upper Cretaceous Mesaverde Group, and (3) a map showing elevation to 0.75 percent $\mathrm{R}_{\mathrm{m}}$ (the onset of gas generation from type III kerogen) and the formations in which it occurs. Using these maturity maps, we can infer zoncs of no generation, the onset of significant gas generation and the areas of maximum gas generation and expulsion for the Mesaverde Group throughout the Uinta Basin (see Nuccio and others, 1991; Nuccio and Fouch, in uress).

A cross-section showing the thermal maturity and general types of kerogen for Cretaceous and Tertiary 


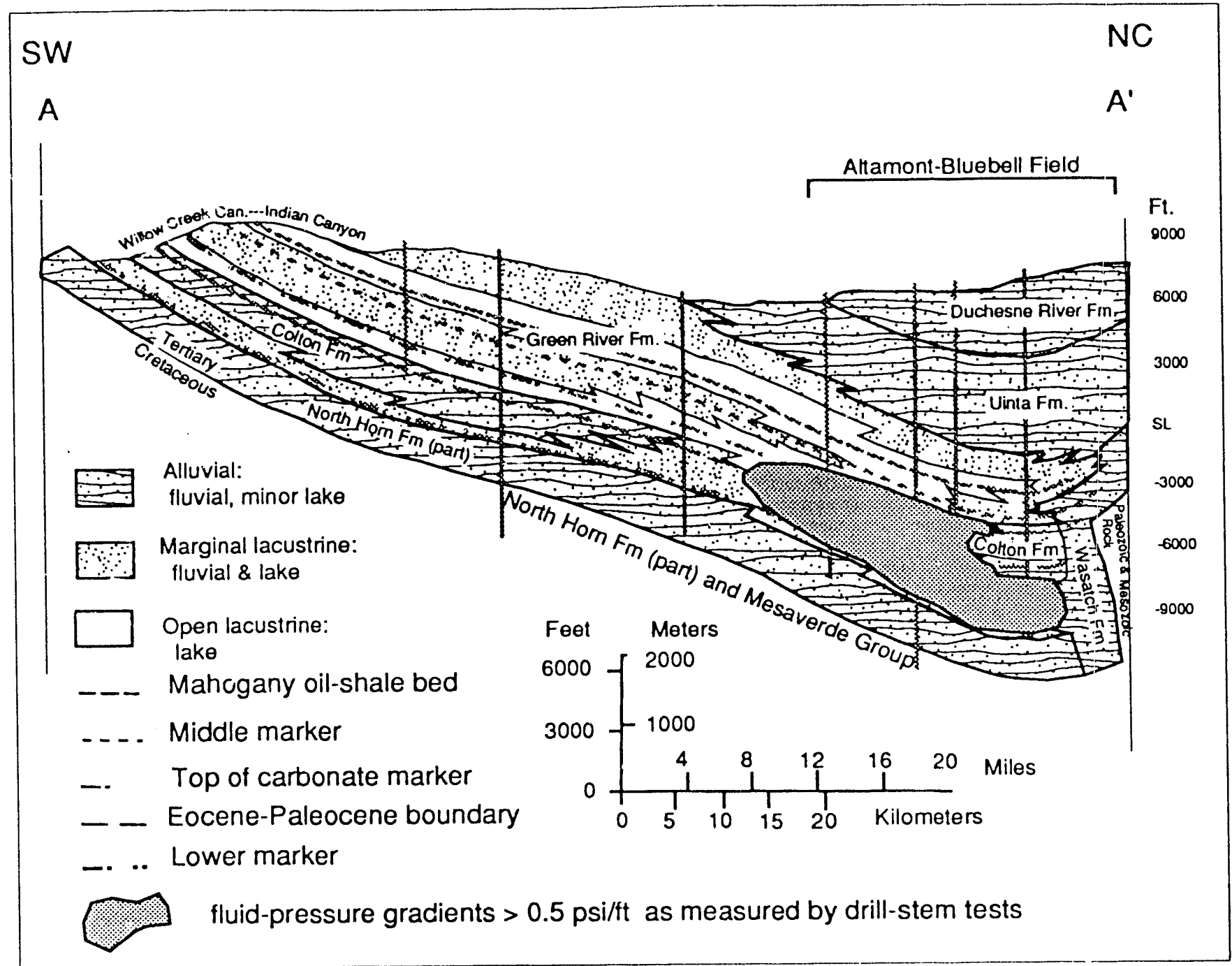

Figure 27. Generalized structural-stratigraphic cross section A-A' showing aren of fluid-pressure gradients: $>0.5$ psilft as measured by drill-stem tests (modified from Fouch, 1975). Abnormal fluid-pressure gradients are confined to Tertiary strata. Highest fluid-pressure gradients are located in that part of the subsurface where impermeable rocks exceptionally rich in hydrogen-richorganic matter have been subjected to sufficient heat to transform thermochemically their organic matter into petroleumlike compounds at such a rate, and in such volume that the increase in volume of petroleum has effected an increase in fluid-pressure gradients. Although as yet untested in the structurally lowest (and hottest) part of the basin, organicallyenriched units of the Mesaverde Group that are encased in impermeable strata can be expected to be somewhat overpressured. See figures $4,5,7$, and 32 for additional information relative to cross section, and figure 3 for approximate line of section.

rocks through the Uinta Basin is presented (see fig. 1). Two maps, one for the base and one for the top of the Mesaverde (figs. 28 and 29), showing $R_{m}$ lines and the area where porosity does not decrease as a function of increasing thermal maturity are presented in the "maturity-porosity trends and their relation to $\mathrm{R}_{\mathrm{m}}$ " section later in this paper (fig. 48 and 49 ).

\section{Mesaverde Group Kerogen Type and Potential}

Several models have been developed relating the generation of hydrocarbons to types of kerogen and thermal maturity; Tissot and others (1974), Dow (1977), Waples $(1980 ; 1985)$. Three general types of kerogen have the potential, under optimum conditions, to generate hydrocarbons: Type I, alginite--sapropelic or lipid-rich; Type II, exinite-phytoplankton, zooplankton, and other microorganisms, and Type III vitrinitehuminite (terrestrial plant debris).

Type I kerogen is hydrogen-rich, occurs primarily in marine and lacustrine rocks and generates mainly oil during catagenesis. The onset of oil generation from type I organic matter varies depending on the model one chooses. There is no absolute point at which hydrocarbon begins to be generated, and it probably 


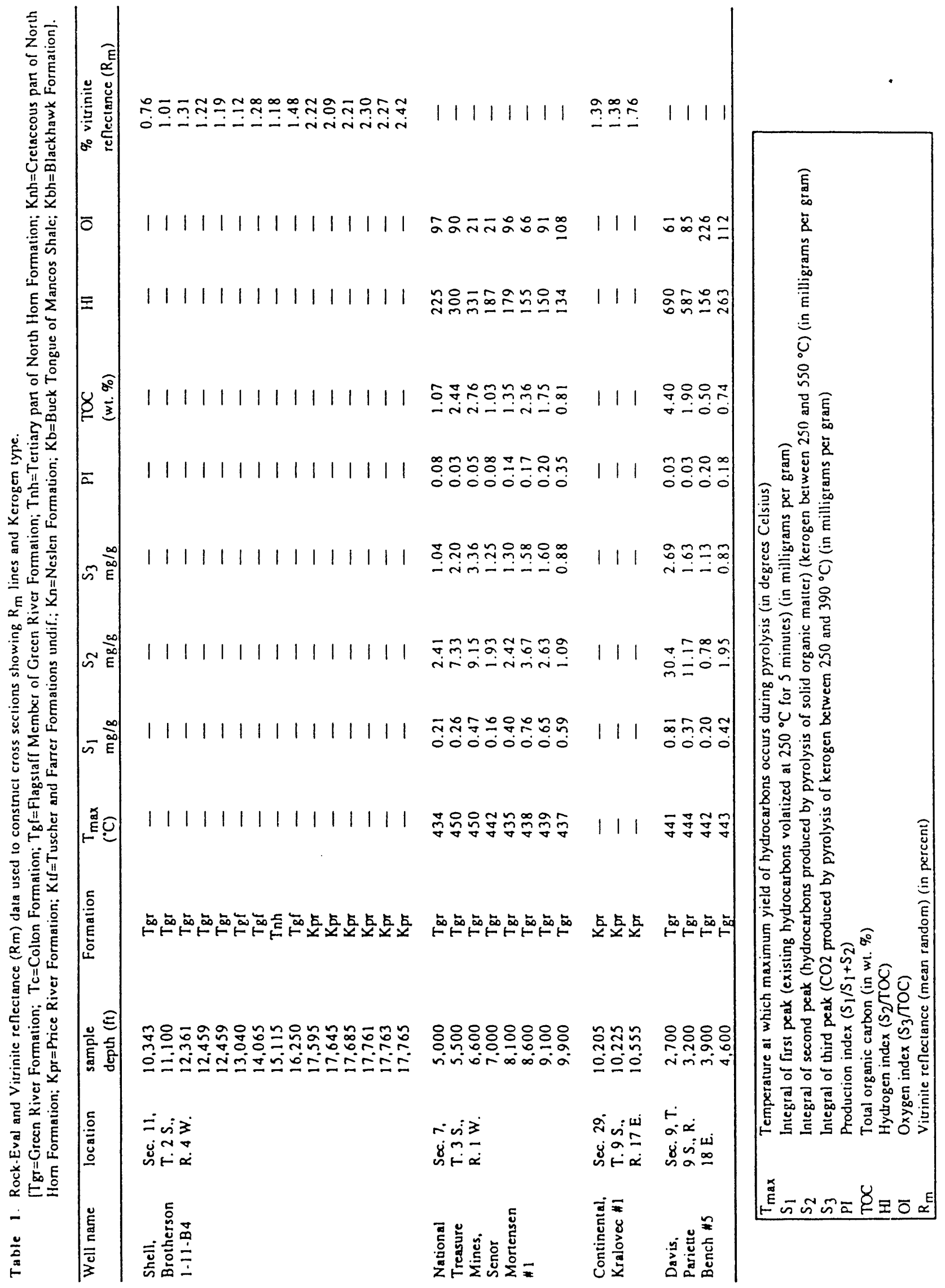




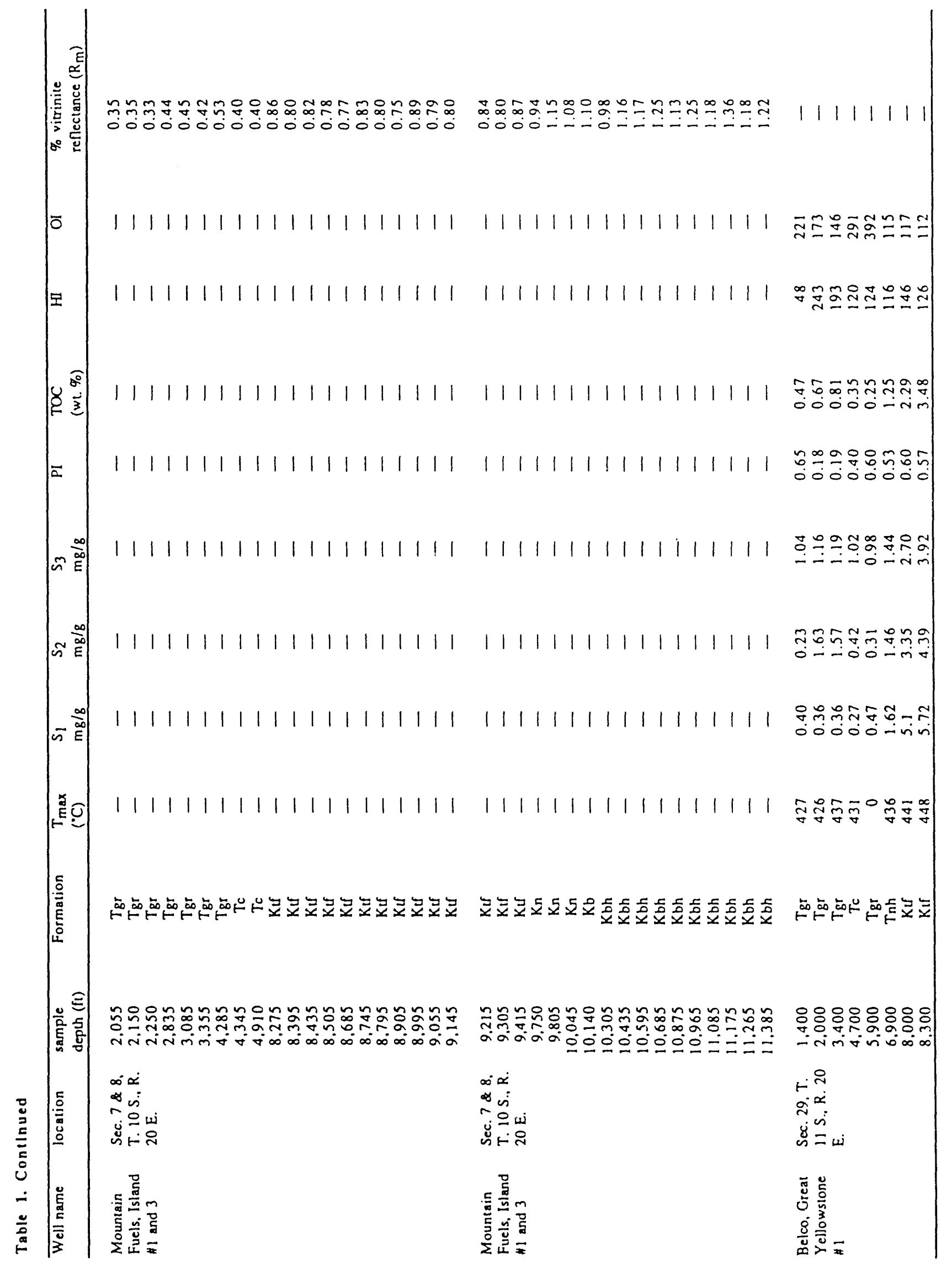


begins over a range of $R_{m}$ values depending on the specific type of organic matter. Dow, (1977) uses 0.50 percent $R_{m}$ as the onset of oil generation for Type I kerogen, while Anders and Gerrild (1984), and Tissot and Welte (1984) use 0.70 percent $R_{m}$.

Type II kerogen occurs mainly in marine rocks, but can occur in lacustrine rocks as well, and generates mostly oil during catagenesis. Waples (1985) stated that oil generation begins over a range of $R_{m}$ values of about 0.45 percent to 0.50 percent for high-sulfur kerogen to 0.60 percent for "typical" type 11 kerogen.

Huminite and vitrinite or Type III kerogen is oxygen-rich and hydrogen-poor, occurs mainly in terrestrial, marginal lacustrine, or marginal marine rocks, and generates mainly methane gas during maturation. For type III kerogen, vitrinite reflectance is the best and most widely used measure of thermal maturity. Two important $R_{m}$ thresholds are used to define regions of gas generation from type III kerogen; these are 0.75 percent and 1.10 percent. An $R_{m}$ of 0.75 percent represents the maturity required for the onset of significant gas generation (Juntgen and Karweil, 1966; Juntgen and Klein, 1975). Gas accumulations found in rocks with an $\mathrm{R}_{\mathrm{m}}$ less than 0.75 percent either contain early biogenic gas, or gas migrated in from more mature source rocks. In the Piceance basin, it appears that lowpermeability Mesaverde rocks have negligible gas production where the Mesaverde is less than an $R_{m}$ of 0.73 percent (Johnson, 1989; Johnson and others, 1987). An $R_{m}$ of 1.10 percent represents the level of maximum gas expulsion from type III kerogen (Meissner, 1984). The upper limit of maturity for gas preservation is still unknown, but could be as high as 4.0 percent $R_{m}$ (Waples, 1980).

Types I, II and III kerogen are present in the Green River Formation (Paleocene and Eocene), and these rocks have generated large amounts of oil and gas in the Uinta Basin (cross section A-A', fig. 5; B-B', fig. 6). The thick Mancos Shale (Upper Cretaccous) is probably compositionally similar to the Mancos in the Piceance basin, where it contains significant amounts of types II and III kerogen and has generated oil and gas (Johnson and Rice, 1990). The nonmarine to nearshore marine Mesaverde Group contains dominantly type III kerogen, and has the potential to generate large amounts of methane gas (Pitman and others, 1987).

\section{Rm Map at Base of the Mesaverde Group.}

Figure 28 is an $R_{m}$ map at the base of the Mesaverde Group. The map shows a general trend of increasing maturity from south to north. This trend generally follows the structural configuration on the base of the
Mesaverde (see fig. 16) which indicates that maturity was set prior to (at maximum burial) or during carly stages of structural movement. In some areas, however, the $\mathrm{R}_{\mathrm{m}}$ lines cut across structure indicating that maturity continued during or for some time after structural movement. It is likely that toward the deepest pan of the basin, maturation at the base of the Mesaverde continued to increase during or after uplift and crosion that began $10 \mathrm{Ma}$ (Miocene). On the nanks of the basin, however, maturity pattems may have been achieved prior to uplift.

Four $\mathrm{R}_{\mathrm{m}}$ lines and three zones of hydrocarbon generation are shown. The 0.65 percent $R_{m}$ line is for reference, and shows the maturity of the base of the Mesaverde around the edge of the basin. The areas of the basin which have not achieved a maturity of 0.75 percent, not mature enough for significant gas generation, are shown by the light stipple pattern. The 0.75 percent $R_{m}$ line indicates the onset of significant gas generation from type III kerogen at the base of the Mesaverde. The area between 0.75 percent and 1.10 percent $R_{m}$ (darker stipple) is where one would expect to begin encountering gas generation and accumulation in Mesaverde reservoirs. The area north of 1.10 percent $R_{m}$ (darkest pattem) is the zone of maximum gas generation and expulsion. The upper limit of gas generation in the northern and decpest, undrilled par of the basin is unknown at this time. The 1.50 percent $\mathrm{R}_{\mathrm{m}}$ line is for reference only.

The base of the Mesaverde is greater than 0.75 percent $R_{m}$ over a large area of the Uinta B asin. Except for the margins of the basin, where subsidence and burial depths were less, gas was probably being generated as Tertiary sediments were being deposited, in Paleocene or early Eocene time, and this generation continued until $10 \mathrm{Ma}$ when uplift and erosion began a regional cooling. In the deepest part of the basin, where the effect of uplift and erosion are not as great, if temperatures were still high enough, and kerogen was available (not "cooked out"), gas generation may have continued after $10 \mathrm{Ma}$ and may be continuing ioday. It is likely that this gas was trapped in "tight reservoirs" throughout the generation history of the Mesaverde, and the pods of high fluid pressures ( $>0.5 \mathrm{psi}$ ) found in the basin today may mark the areas of active generation.

\section{Rm Map at the Top of the Mesaverde Group}

Figure 29 is the $\mathrm{R}_{\mathrm{m}}$ map at the top of the Mesaverde Group. $R_{m}$ lines generally follow the structural configuration of the top of the Mesaverde (sce fig. 15), suggesting that maximum maturity was achieved prior 


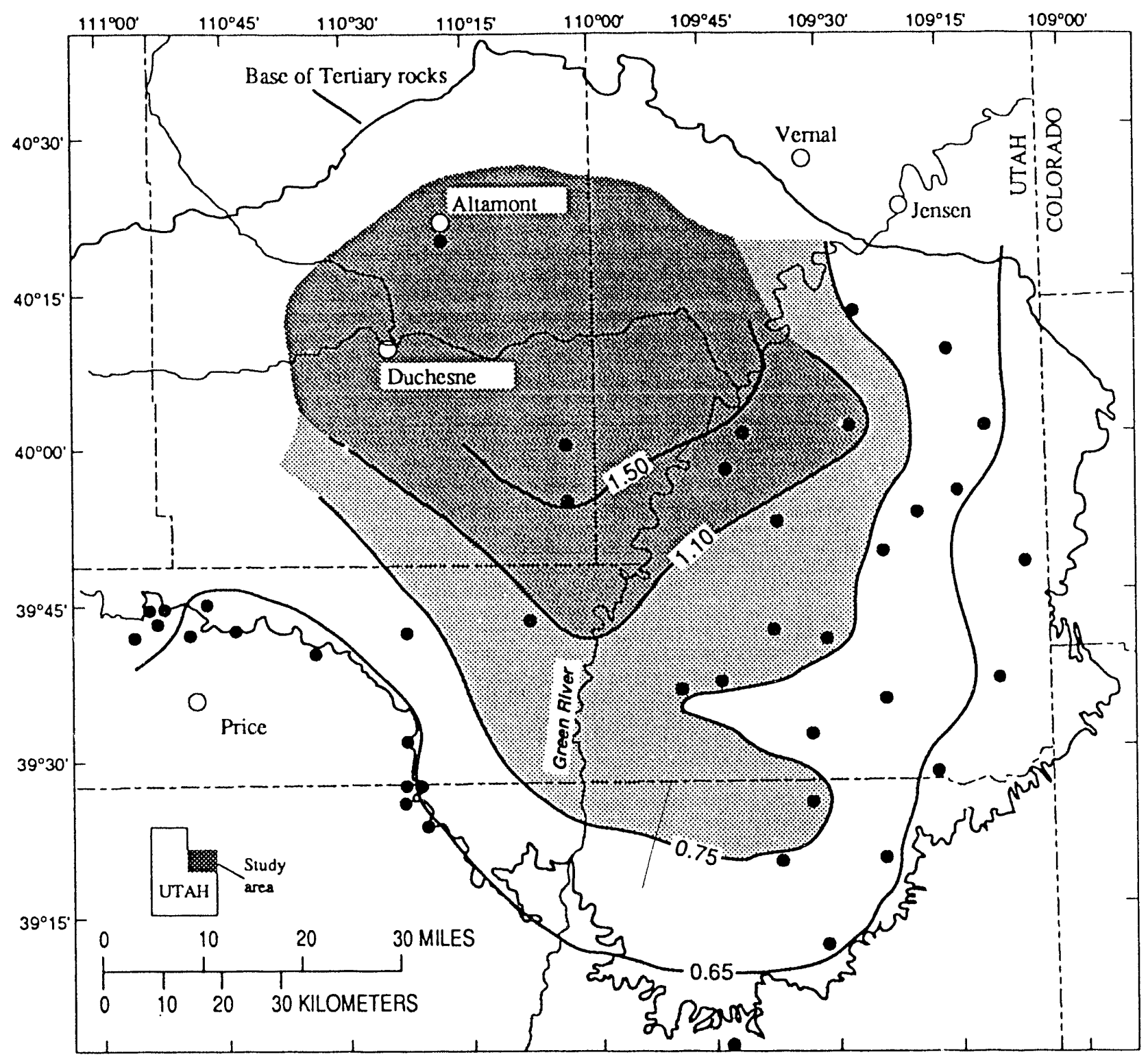

Figure 28. Vitrinite reflectance ( $R_{\text {}}$ ) map showing thermal maturity on the base of the Mesaverde Group, Uinta Basin, Utah. The map indicates areas of no gas generation (light stipple pattern), significant gas generation $\left(0.75\right.$ to 1.10 percent $R_{m}$ isoreflectance line, and darker stipple pattern), and maximum gas generation and expulsion $\left(>1.10\right.$ percent $R_{m}$ isoreflectance line and darkest pattern). Dots are location of analyzed samples.

to, or during the early stages of Late Paleogene and Neogene structural movement and at maximum burial. As with the map of the base of the Mesaverde, $R_{m}$ lines in some areas cut across structure, indicating continued maturation during or after structural movement. Equivalent $R_{m}$ lines on the top of the Mesaverde are located further to the north than those at the base, suggesting a greater area of less mature rock at the top of the Mesaverde. This pattern is a direct result of relatively shallower depth of burial on the top of the Mesaverde.

Five $R_{m}$ lines and three zones of hydrocarbon generation are shown. The 0.50 percent and 0.60 percent $\mathrm{R}_{\mathrm{m}}$ lines are for reference, and show the general maturity for the top of the Mesaverde where it outcrops around the edge of the basin. For the area south of the 0.75 percent $R_{\mathrm{m}}$ line (light stipple pattern), one would not expect significant gas generation from source rocks near the top of the Mesaverde. The area between the 0.75 percent and 1.10 percent $R_{\mathrm{m}}$ lines (darker stipple pattem) is the zone of significant gas generation, and the area north of the 1.10 percent $R_{m}$ line (darkest pattem) is the zone of maximum generation and expulsion for source rocks near the top of the Mesaverde. The 2.0 percent $R_{m}$ line is for reference only, but in- 


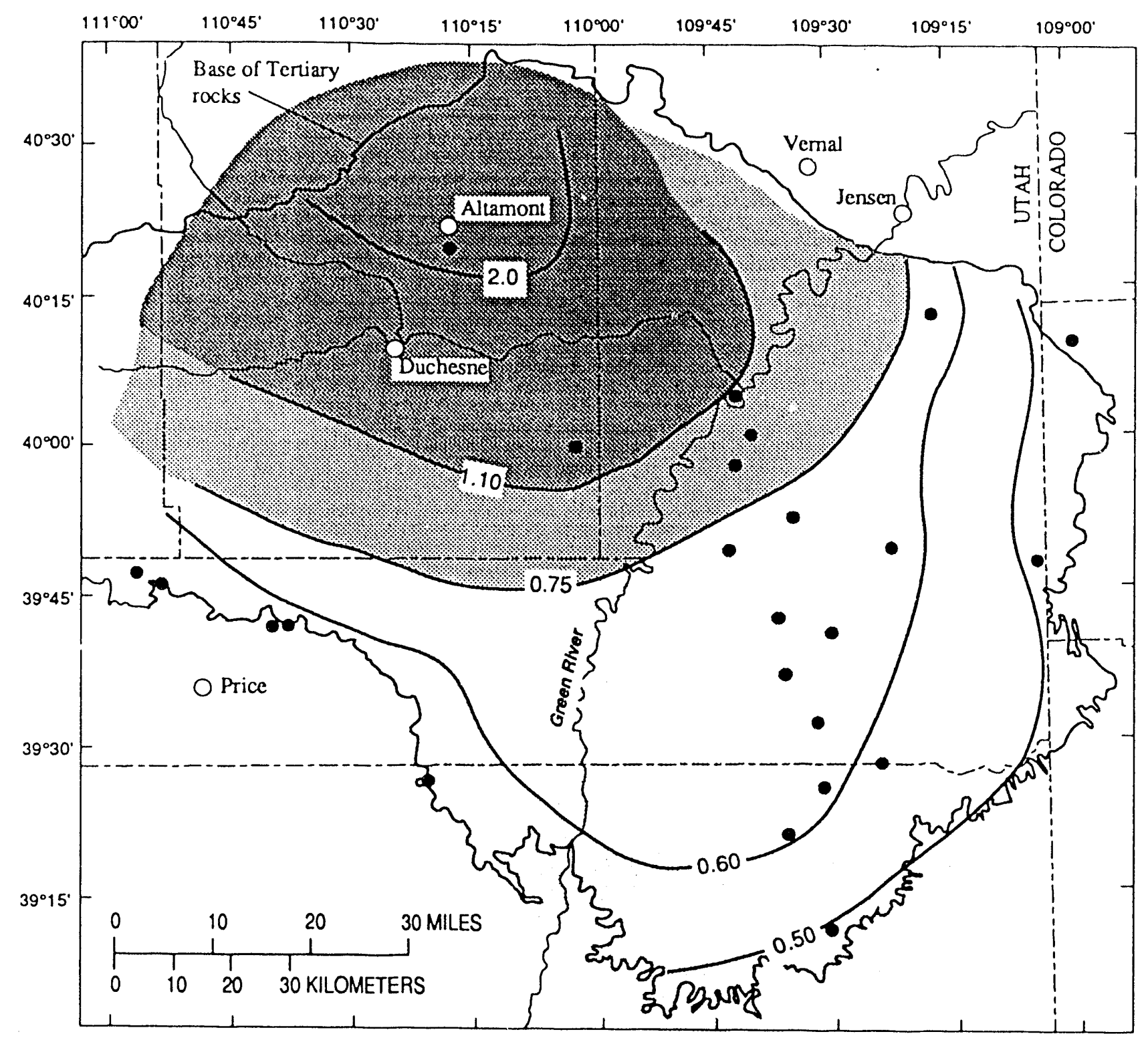

Figure 29. Vitrinite reflectance $\left(R_{m}\right)$ map showing thermal maturity on the top of the Mesaverde Group, Uinta Basin, Utah. The map indicates areas of no gas generation (light stipple pattern), significant gas generation $\left(0.75\right.$ to 1.10 percent $R_{m}$ darker stipple pattern), and maximum gas generation and expulsion (>1.10 percent $R_{m}$ and darkest pattern). Dots are location of analyzed samples.

dicates maturity at the top of the Mesaverde in the most deeply-drilled part of the basin. As discussed earlier, the upper limit for gas preservation is not well defined.

The area where the top of the Mesaverde is greater than 0.75 percent $R_{m}$ is less than that at the base, and occurs further north in the deeper part of the basin. Again this pattem is due to shallower depths of burial on the top of the Mesaverde. Therefore, gas generation for the top of the Mesaverde began later than for the base, probably not until at least Eocene or Oligocene time. This timing agrees with Pitman and others (1987), who constrain timing of gas generation from the Upper Cretaceous Blackhawk and Neslen Forma- tions to Oligocene and Miocene time. As with the base of the Mesaverde, gas generation continued through the Tertiary and was accumulating in nearby reservoirs. From $10 \mathrm{Ma}$ (Miocene) to present, gas generation has ceased at the top of the Mesaverde where it is exposed or at shallow depths, however in the deeper parts, where temperatures are sufficient, active generation is still probable today.

\section{Map Showing Elevation to $\mathbf{0 . 7 5}$ percent $\mathrm{R}_{\mathrm{w}}$}

Figure 30 is a map showing the elevation to the 0.75 percent $R_{m}$ line within the basin; the threshold for significant gas generation. The 0.75 percent $R_{m}$ line cuts 


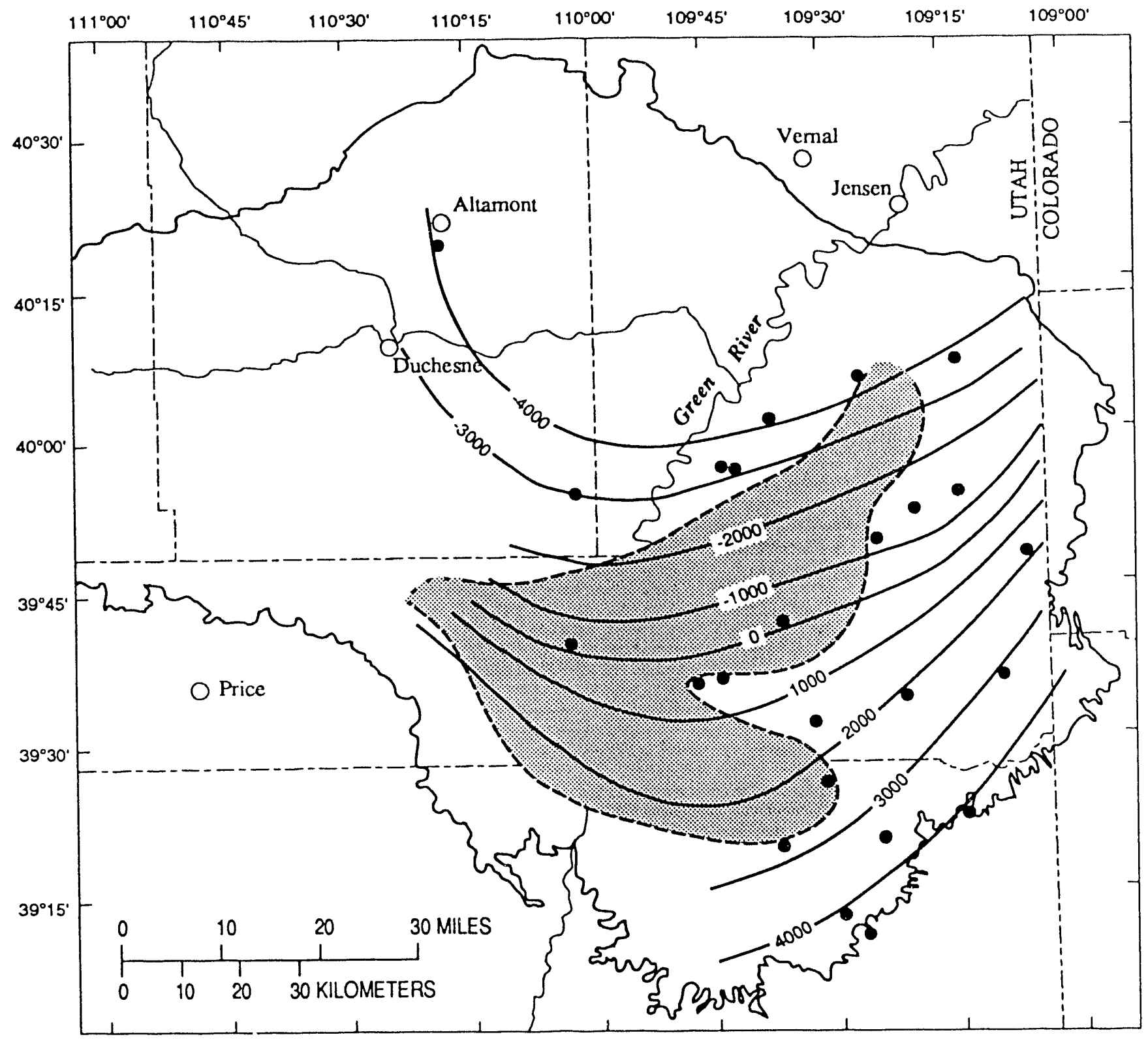

Figure 30. Elevation relative to sea level of the 0.75 percent isoreflectance line (onset of significant gas generation), Uinta Basin. Utah. Shaded pattern indicates area where the 0.75 percent isoreflectance line passes through Mesaverde Group strata. South and east of the shaded area, the 0.75 percent isoreflectance line occurs in pre-Mesaverde Group rocks. North of the shaded area, the 0.75 percent isoreflectance line occurs in Tertiary rocks. Dots are location of analyzed samples.

across formation boundaries and stratigraphically rises to the north. For example, in the southemmost part of the basin, 0.75 percent $R_{m}$ occurs in the Mancos Shale, whercas in the northern part of the basin near Altamont, 0.75 percent $R_{m}$ occurs between the middle and carbonate markers of the Green River Formation. The reason for this can be related to the structural movement and variations of burial depth in the basin. After final movement, the flanks of the basin were eroded to greater depth than the structural center of the basin. However in the center of the basin, where the effect of uplift and erosion was less, and sediment continued to accumulate, the rocks continued to mature causing the $0.75 \%$ isoreflectance line to stratigraphically rise to higher positions.

The shaded pattern on figure 30 is the area where the 0.75 percent $R_{m}$ line occurs in the Mesaverde Group. This map is useful in that it approximates at what elevation (easily converted to depth) one would have to drill to encounter the threshold for significant gas generation, and in which formation it could be found. 


\section{Cross-section Showing Rm Lines and Kerogen Type Through the Uinta Basin}

Seventy-two samples were analyzed for vitrinite reflectance and Rock-Eval pyrolysis to determine thermal maturity and kerogen type for wells along a line of section through the Uinta Basin (see table 1 and fig. 6). Figure 31 shows the types of kerogen at various stratigraphic levels in the Mesaverde Group and Green River Formation. This is, of course a section through only a small portion of the basin and core suitable for optimum analysis is limited for many stratigraphic intervals and depositional facies, and one would expect the kerogen type to change as facies change in other parts of the basin. The analyses show Type I kerogen only in a limited area around the Mahogany zone. The majority of the section contains a mixture of Types II and III kerogen with a few zones of Type III kerogen. Kerogen types have been shown for the entire section. However, it should be noted that in many areas in this section, rocks are organically-lean or barren.

For the same section, $\mathrm{R}_{\mathrm{m}}$ lines have been superimposed as well (fig. 31). As discussed earlier, the $R_{m}$ lines climb stratigraphically going north, toward the decper part of the basin. The 0.50 percent $R_{m}$ line is shown to indicate where Type I and II rocks should be mature enough for oil generation. It is interesting to note that the oil-producing zones are found where mixed Type II - III kerogen and the optimum-maturity range for oil generation ( $>0.50$ percent $\left.R_{m}\right)$ occur. The 0.75 percent $R_{m}$ line indicates where the onset of significant gas generation for type III kerogen should occur. Not surprisingly, the gas-producing zones coincide with type III kerogen and $R_{m}$ of around 0.75 percent. The 1.10 percent $R_{m}$ line is shown to indicate where maximum gas generation and expulsion would be found for type III kerogen. The 2.0 percent $R_{\mathrm{m}}$ line is given to show the maturity for the top of the Mesaverde in the deeper part of the basin.

\section{Rm and Fluid-Pressure Gradients}

The 0.75 percent $R_{m}$ line has been used to define the threshold at which significant gas generation begins. Assuming this also marks the beginning of overpressuring, one should be able to map overpressuring in the Uinta Basin using the Rm maps. In attempting this, we found that overpressuring does not always coincide with the 0.75 percent $R_{m}$ line (fig. 32). In fact, overpressuring only occurs in scattered pods throughout the basin. There are four very important variables that must be considered in defining areas of overpressuring: (1) organic matter quality and quantity, (2) timing of gas generation in relation to uplift and erosion, (3) leakage through recently exposed strata and fault zones, and (4) low permeability. In order to have significant gas generation, the quality and quantity of the source rocks must be optimum. If the proper type and amounts of organic matter are present, the timing of gas generation in relation to uplift and erosion must be right. For instance if gas generation is too early, the gas might be lost through fractures associated with later structural movement. If gas generation is too late, it might be lost to late basin faulting, and/or leakage through outcrops created by the downcutting of rivers. The Uinta Basin has had a complex history of Laramide structural deformation, followed by late Miocene-Pliocene uplift and erosion that has formed deeply dissected canyons. Permeability is important for overpressuring because without a relatively low permeability, the rate of gas loss will keep pace with the rate of gas generation. It is obvious that simply using the 0.75 percent $R_{m}$ line to define the top of overpressuring is not accurate. The only way to define overpressuring in the Uinta Basin is to map it directly using DST's, and/or mud weights, and to use $\mathrm{R}_{\mathrm{m}}$ as a secondary variable only.

\section{$R_{m}$ and Estimates of Removed Overburden}

Several workers have tried to determine amounts of overburden removed across the Uinta Basin. Tissot and others (1978) estimated $5,840 \mathrm{ft}$ of overburden removal from the site of the Shell 1-23-B4 Brotherson well in the Altamont-Bluebell field in the trough of the basin. Narr and Currie (1982) used fluid inclusions to determine overburden removal from the AltamontBluebell area and had greatly varying results ranging from 1,112 to $9,482 \mathrm{ft}$ of removal. Pitman and others (1982) estimated no more than $3,300 \mathrm{ft}$ of removal from the Pariette Bench field, and Pitman and others (1987) estimated that $3,300 \mathrm{ft}$ of overburden have been removed from the Natural Buttes field area. Sweeney and others (1987) estimate that between 5,000 and $9,000 \mathrm{ft}$ of rock have been eroded from the area of Altamont-Blucbell.

Johnson and Nuccio (in press) have used $R_{m}$-depth profiles to estimate amounts of overburden removed in different parts of the Uinta Basin as well. Surface Rm points were combined with nearby well data to construct semilogarithmic Rm-depth profiles. These plots, when extrapelated to an original surface $R_{m}$ value of between 0.20 percent to 0.30 percent (when the basin was at maximum burial) should yield an estimate of removed overburden (Dow, 1977 for method). 
NC

B
EC

B'

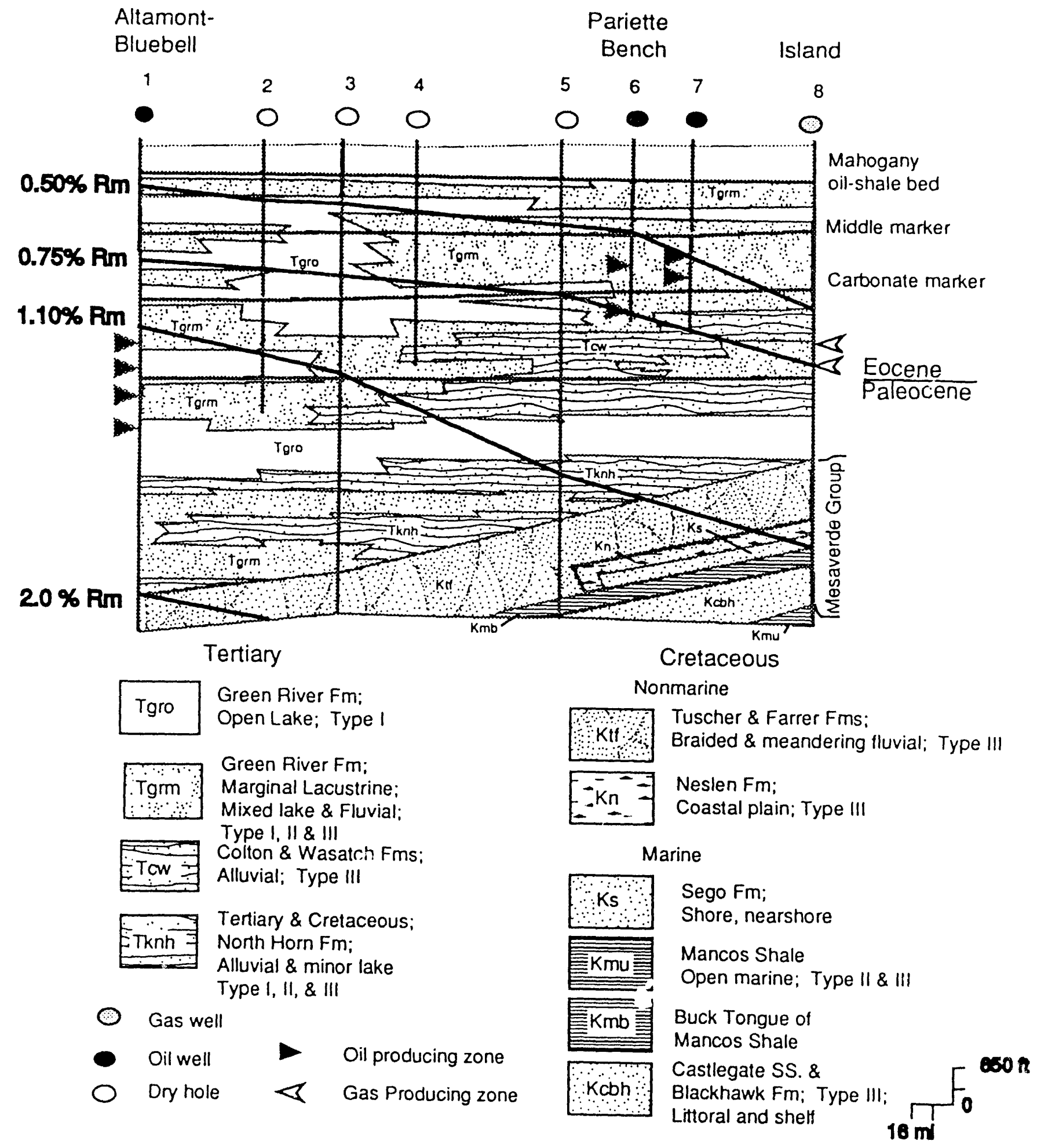

Figure 31. Cross-section B-B' through the Uinta Basin, Utah (also see fig. 6) showing vitrinite isoreflectance lines, types of kerogen found at various stratigraphic intervals, and the associated hydrocarbon producing zones. Refer to figure 3 for
line of section. 
NC

EC

$\mathrm{B}$

$B^{\prime}$

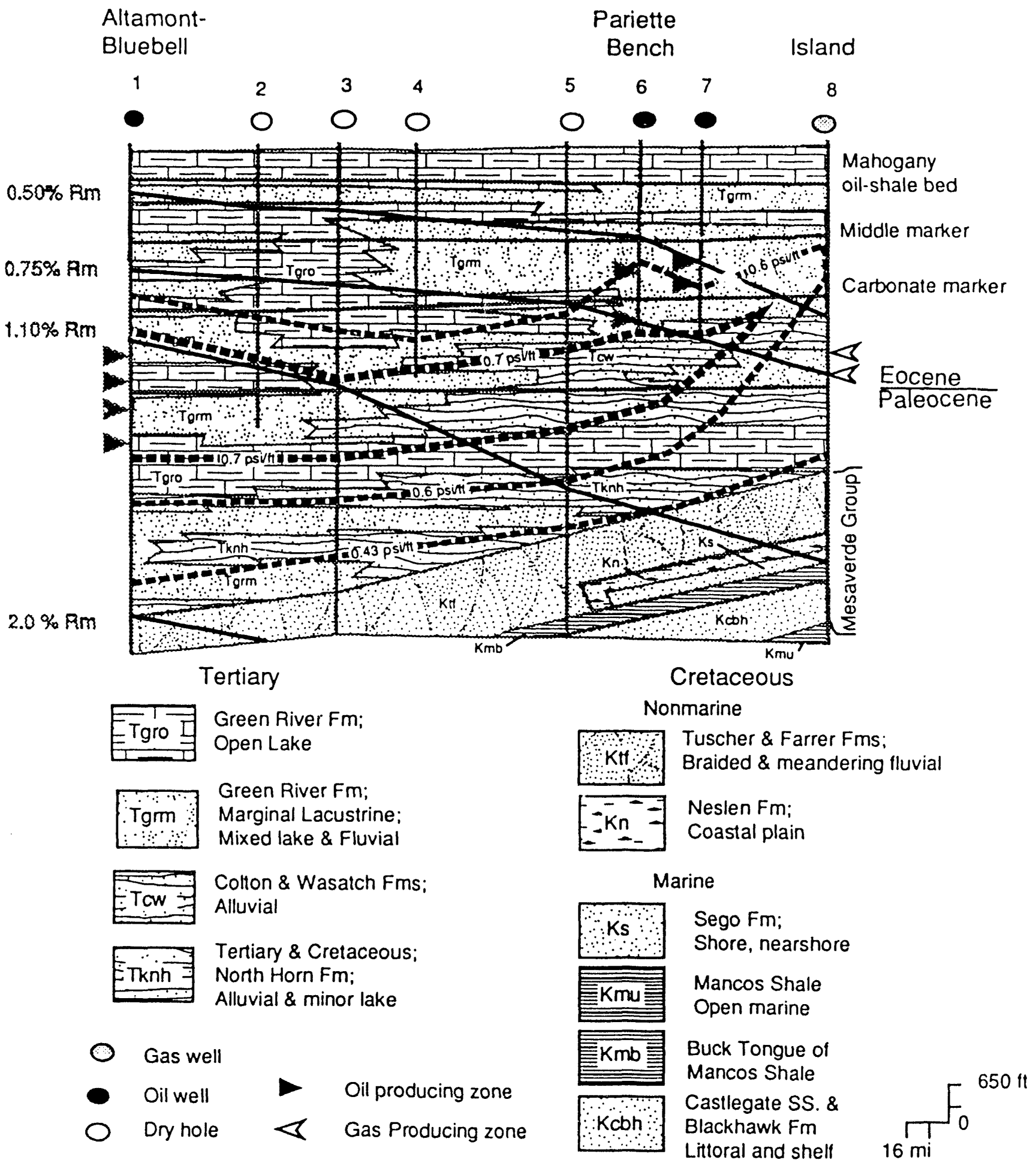

Figure 32. Cross-section $B-B^{\prime}$ through the Uinta Basin. Utah (see figs. 6 and 27) showing vitrinite isoreflectance lines, and fluid-pressure gradients in psilft as measured by drill-stem tests (modified from Fouch, 1975). Abnormal fluid-pressure gradients are confined to Tertiary strata. Highest fluid-pressure gradients are located in that part of the subsurface where impermeable rocks exceptionally rich in hydrogen-rich organic matter have been subjected to sufficient heat to transform thermochemically their organic matter into petroleumlike compounds at such a rate, and in such volume that the increase in volume of petroleum has effected an increase influid-pressure gradients and the associated hydrocarbon producing zones. 
Three $\mathrm{R}_{\mathrm{m}}$-depth profiles were constructed for the Uinta Basin. Extrapolating the profile of the MidAmerica \#1 Unit well (sec. 24, T. 9S, R. 24E) near the eastem edge of the basin to 0.30 percent $R_{m}$, gives a thickness of overburden removed of about 4,000 ft. Extrapolating this profile to 0.20 percent $R_{m}$ gives an estimate of about $9,000 \mathrm{ft}$ of overburden removal. This contrasts markedly with the extrapolation to the $R_{m}$ profiles for the Mountain Fuels \# 1 and \#3 wells (sec. 8 , T. 10S., R. 20E). The combined profile for these wells does not plot in a straight line and forms a kink near the middle of the Mesaverde Group. The extrapolation of this profile to 0.30 percent $R_{m}$ yields a depth of about $900 \mathrm{ft}$ below the present-day surface while extrapolating to 0.20 percent $R_{m}$ gives an estimate of about 2,300 $\mathrm{ft}$ of overburden removed. An $\mathrm{R}_{\mathrm{m}}$ profile has been constructed for the Shell Brotherson 1-11-B4 well from about $10,000 \mathrm{ft}$ to TD at nearly $18,000 \mathrm{ft}$. We have an $R_{m}$ point at the present-day surface as well, however, there is no data from $10,000 \mathrm{ft}$ to the surface. This gap makes extrapolation somewhat tenuous, especially if there are kinks in the profile (see Law and others, 1989). For the Shell Brotherson 1-11-B4 well (sec. 11, T. 2S., R. 4W), located in the Altamont-Bluebell field extiapolating to 0.30 percent $R_{m}$ gives an estimate of $6,200 \mathrm{ft}$ removed, and extrapolation to 0.20 percent $R_{m}$ yields an estimate of $11,000 \mathrm{ft}$ of overburden removed.

Projection of maturity values and fluid-pressure data into undrilled parts of the basin reveals the probability of a regional, overpressured, basin-centered gas accumulation, where gas generation is likely to be occurring at present. Published estimates of amounts of erosion in the region vary widely, ranging from $1,000 \mathrm{ft}(300 \mathrm{~m})$ to almost $11,000 \mathrm{ft}(3,350 \mathrm{~m})$. Our interpretation favors the lesser erosional estimates, because of consistency with structural and stratigraphic reconstructions, and maturation patterns, and because significant cooling of strata due to uplift and erosion would slow or stop the generation of hydrocarbons.

\section{ORIGINS AND CHEMICAL TYPES OF NATURAL GASES}

Natural gas is generated from organic matter throughout the burial history of sedimentary rocks during three main stages (fig. 33). The generation of hydrocarbons is controlled mainly by thermal history, whereas the amount and composition of the hydrocarbons generated is controlled by kinetics of kerogen composition (Bumham and others, 1987; Tissot and others, 1987; Mackenzie and Quigley, 1988). At shallow depths of burial (diagenesis or immature zone), bacterial or microbial gas is generated by the decomposition of organic matter by anacrobic bacteria. During catagenesis and metagenesis, the rmochemical processes become prevalent and products are referred to as thermogenic. During early catagenesis, both liquid and gascous hydrocarbons are gencrated, mainly from hydrogen-rich types I and II kerogens; these types of kerogen predominantly occur in rocks deposited in lacustrine and marine environments. With increasing thermal maturity and during later catagenesis, lighter hydrocartons are formed by cracking of previously generated heavier hydrocarbons and by generation from oxygen-rich type III kerogen. Type III kerogen is commonly associated with rocks deposited in nonmarine environments. During metagenesis, kerogen begins to evolve to graphite and methane is the principal stable hydrocarbon.

Natural gases can be distinguished by their chemical and isotopic composition (James, 1983; Rice, 1983; Schoell, 1983) (fig. 34). Bacterial gas consists predominantly of methane that is depleted in ${ }^{13} \mathrm{C}\left(\partial^{13} \mathrm{C}_{1}\right.$ values more negative than $-55 \mathrm{ppt}$ ) because of biological enrichment (Rice and Claypool, 1981). During catagenesis, thermogenic methane, which is commonly accompanied by heavier hydrocarbons, is isotopically heavier than bacterial methane $\left(\partial^{13} \mathrm{C}_{1}\right.$ values of about 55 to $-35 \mathrm{ppt}$ ) because of smaller kinetic isotopic effects associated with thermal cracking processes. During late stages of thermal history (metagenesis), natural gas becomes devoid of all heavier hydrocarbons and the isotopic composition of the methane approaches that of the original organic matter $\left(\partial^{13} \mathrm{C}_{1}\right.$ values are more positive than $-35 \mathrm{ppt}$ ).

Natural gases show a continuous gradation of chemical and isotopic compositions. The factors that are primarily responsible for the gradations are (1) mixing of gases of different origins and generated at different levels of thermal maturity and (2) effects of different types of organic matter. These factors can usually be recognized by using carbon and hydrogen isotope compositions of various gas components (James, 1983,1990; Schoell, 1983, 1988).

Nonhydrocarbon gases, such as nitrogen, carton dioxide, and hydrogen sulfide, can also be abundant in hydrocarbon accumulations. They tend to be more plentiful at greater depths and higher levels of thermal maturity and their occurrence is usually not related to the generation of hydrocarbons from organic matter.

\section{Methods of Gas Analysis}

Gas samples were analyzed by thermal-conductivity gas chromatography. Volume percent of methane, 

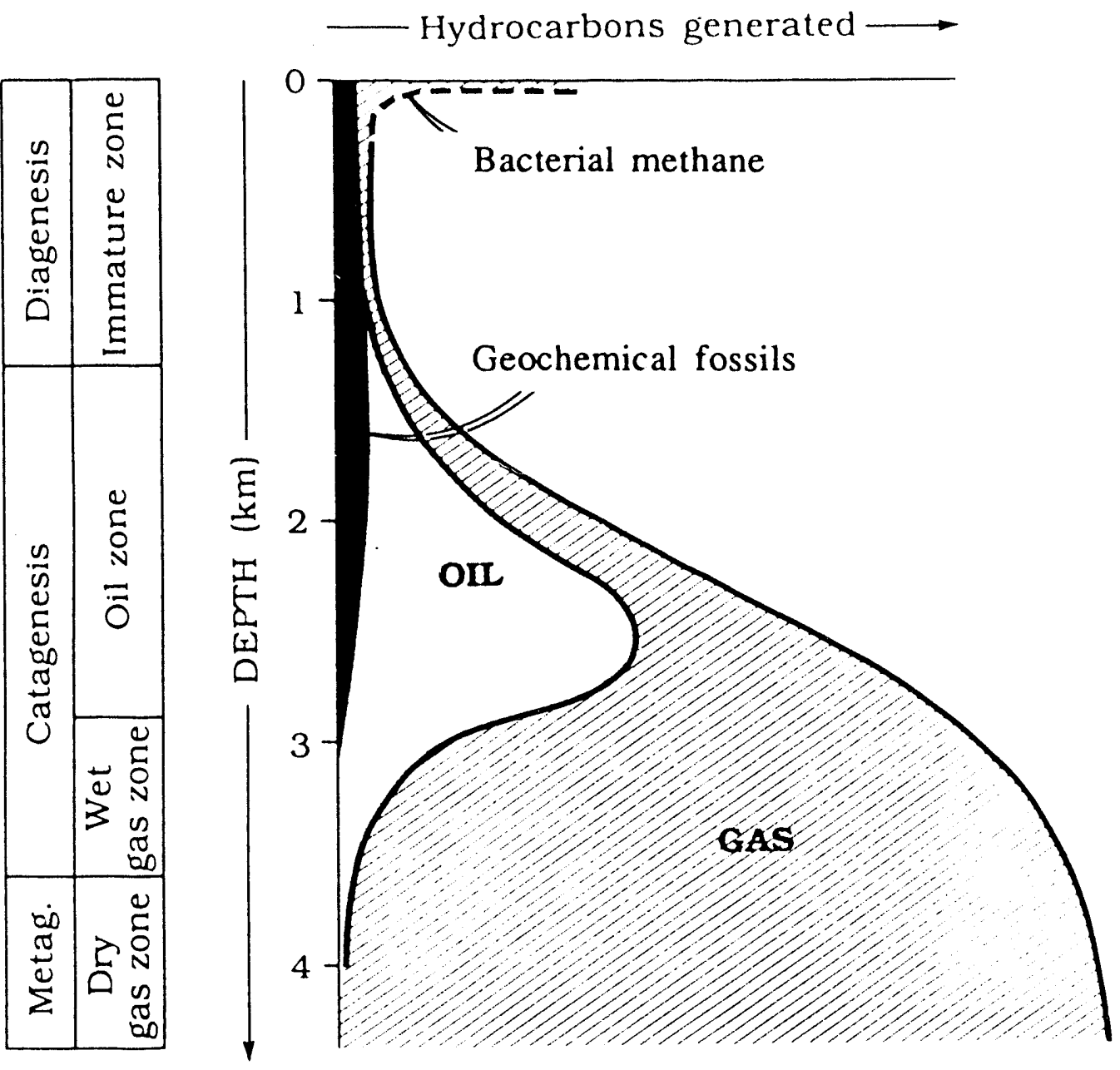

Figure 33. Diagram of hydrocarbon generation as a function of depth of burial. After Tissol and Welte (1984). Geochemical fossils occur throughout the black zone.

ethane, propane, butane, pentane, carbon dioxide, and nitrogen and/or air were measured. Methane and ethane were prepared for isotopic analysis using methods similar to those described by Schoell (1980). Carbon and hydrogen isotope ratios were measured on a Neir-McKinney type mass spectrometer and are reported in $\partial$-notation in parts per thousand (ppt) relative to PDB for carbon and to SMOW for hydrogen.

\section{Results and Discussion of Gases}

Twenty three gas sampies were collected and analyzed from producing wells in the Uinta Basin (table 2). The samples were collected from the Upper Cretaccous Mesaverde Group, Paleocene and Eocene ColtonWasatch and Green River Formations in the AltamontBluebell, Natural Buttes, and Red Wash fields (also see fig. 37 discussed below). Some of the results are summarized in plots shown in figures 35 and 36.

The chemical and isotopic compositions of the gas samples in the Uinta Basin are quite variable $\left(\partial^{13} \mathrm{C}_{1}\right.$ values range from -53.6 to $-34.5 \mathrm{ppt} ; \partial^{13} \mathrm{C}_{2}$ values range from -39.4 to $-29.8 \mathrm{ppt} \partial \mathrm{D}_{1}$ values range from -286 to -166 wetness $\left(C_{2}\right)$ values range from 2.0 to 23.3 percent) over a depth range of 4,102 to $16,887 \mathrm{ft}$ and $\mathrm{Rm}$ values for the top of the reservoirs vary from 0.5 to 1.3 percent (figs. 35 and 36; table 2). These data indicate that the gases are dominantly of thermogenic origin and that they were generated during both catagenesis and metagenesis. However, trends in composition and depth are not obvious, as illustrated by figures 35 and 36 , when considering all of the gas samples. This absence of trends indicates that gas samples from different producing intervals within the 


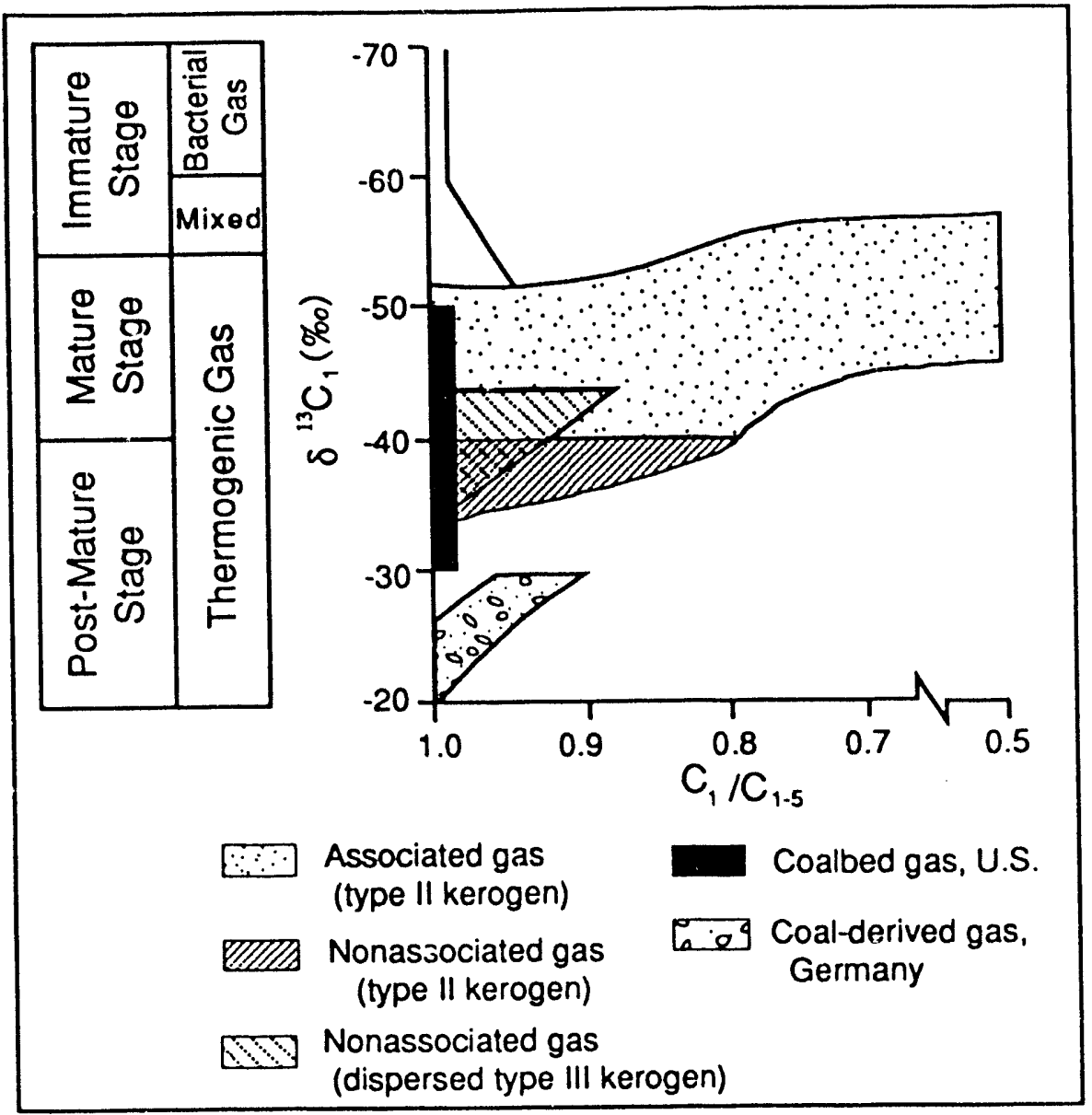

Figure 34. Changes in chemical and isotopic composition of natural gases from different types of source rock during stages of hydrocarbon generation. From Johnson and Rice (1990).

producing fields should be looked at separately to gain insight into their character and origin.

\section{Types of Gas in Basin}

Based on chemical and isotopic composition, two classes (types) of thermogenic gases have been identified in the Uinta Basin (fig. 35). Class A is nonassociated, chemically dry, and isotopically heavy. This gas is interpreted to have been generated from type III kerogen in the Mesaverde Group at high levels of thermal maturity (late catagenesis and metagenesis). This gas occurs in both Mesaverde and Wasatch reservoirs over a wide depth range in the Natural Buttes producing area (fig. 37). The identification of class $A$ gas in both of these reservoirs is important for two reasons. First, the occurrence of gas in Tertiary reservoirs, such as in the Wasatch, will be in areas where conduits for vertical migration are available. These conduits will probably be provided by faults and fractures, which are generally concentrated in the southeast part of the basin (fig. 9). Second, significant amounts of nonassociated gas were generated during peak generation $\left(R_{m}>1.1\right.$ percent) from type III kerogen in the Mesaverde over large parts of the basin. The lower limit of gas generation and preservation from this type of kerogen is probably not present in the basin. Although some of this gas has migrated into shallower Tertiary reservoirs, large amounts of this gas are probably present in tight reservoirs of the Mesaverde.

In contrast, class B gas is chemically wet and isotopically light, and is associated with oil (fig. 35). Class B gas was generated during the time of major oil generation (catagenesis) and from type I kerogen typical of the Green River Formation open lake facies. Thermogenic hydrocarbons were generated in the deep part of the basin to the north (Altamont-Bluebell field area) (fig. 37). The presence of this type of gas in shallow, immature reservoirs in the area of Red Wash field indicates extensive lateral migration from the Altamont-Bluebell field area (fig. 37). This interpreted direction of gas migration (eastward and vertical) is the same as that predicted for fluid flow as interpreted from pressure data (fig. 26). 


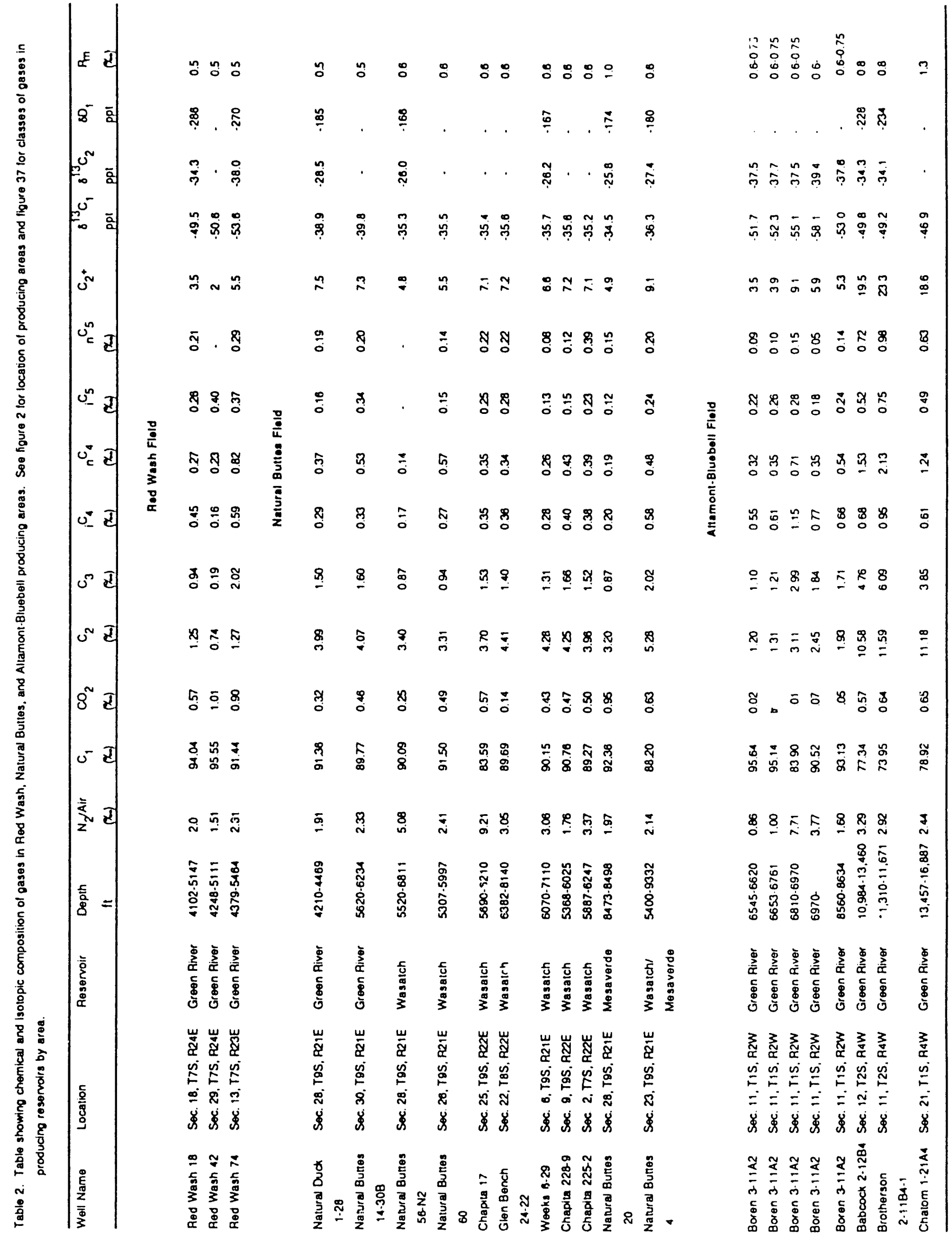




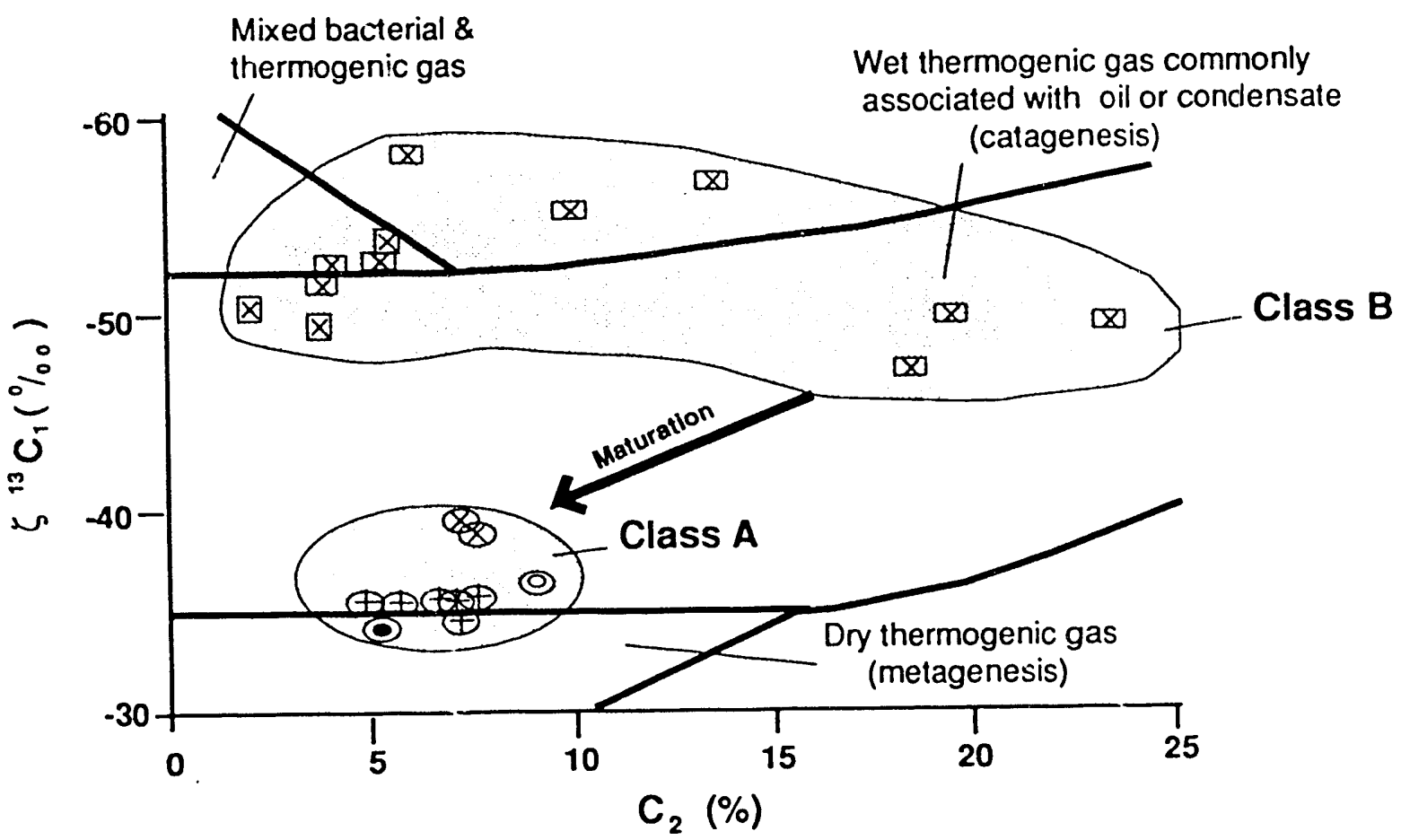

\begin{tabular}{|llll|}
\hline \multicolumn{2}{|c}{ Productlve Stratigraphic Unit } & \multicolumn{2}{c|}{ Productive Fleld } \\
$\times$ & Green River Formation & $\square$ & Altamont-Bluebell \\
+ & Wasatch Furmation & $\square$ & Red Wash \\
- & Mesaverde Group & & Natural Buttes \\
0 & $\begin{array}{l}\text { Mesaverde Group and Wasatch Formation } \\
\text { (commingled) }\end{array}$ & & \\
\hline
\end{tabular}

Figure 35. Methane carbon isotope ratio $\left(\partial^{\prime 3} C_{f}\right)$ versus wetness $\left(C_{2+}\right)$. Class $A$ gas is derived from type III organic matter and is largely derived from alteration of organic matter in the Mesaverde Group. Class B gas is associated with type I organic matter and is largely derived from lake beds in the Green River Formation. Class B gas is commonly associated with oil.

\section{Natural Buttes Field Gas}

In the Natural Buttes field (figs. 2, 7, and 24), mainly nonassociated gas is produced from reservoirs of Upper Cretaceous Mesaverde Group and Tertiary Wasatch and Green River Formations. The major part of production and much of recent exploration activity is in the Wasatch Formation. The gases from the Mesaverde Group and overlying Wasatch Formation are almost identical in chemical and isotopic composition, yet they occur over a depth interval of 5,307 to 9,332 ft (figs. 35 and 36). The composition suggests that the gases were generated during late catagenesis and/or the metagenesis stages of hydrocarbon generation at vitrinite reflectance values in the range of 1.1 to 1.5 percent. Based upon analysis of figures 28 and 29 . generation probably took place in lower part of the Mesaverde Group, which is characterized by this level of thermal maturity in the Natural Buttes area. In contrast, rocks in the Wasatch Formation are probably only marginal mature in reference to hydrocarbon generation in the area. Source rocks in the Mesaverde contain predominantly type III kerogen which generates mostly gas throughout its thermal history and reaches its peak generation in the late catagenesis and/ or metagenesis stages. This interpretation means that the gases produced from tight reservoirs in the Wasatch have probably migrated vertically from the underlying Mesaverde along faults and fractures that are typical of the area (see fig. 9).

Gases produced from shallower reservoirs in the Green River Formation have a similar chemical composition, but are slightly isotopically lighter (fig. 35). These gases are also interpreted to have been mostly generated in and migrated from the decper Mesaverde source rocks during late catagenesis and/or 


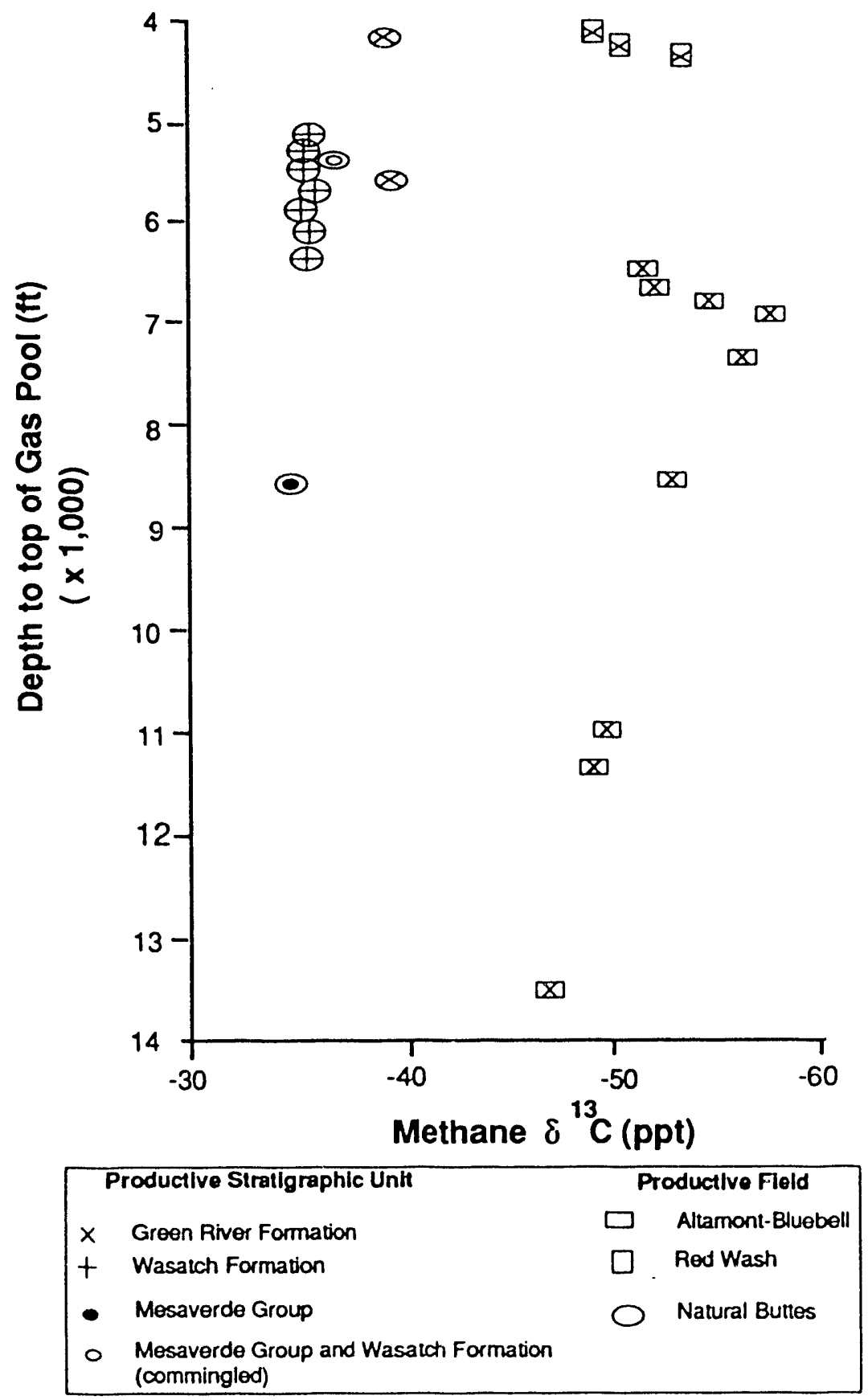

Figure 36. Methane carbon isotope ratio $\left(\partial^{13} C_{1}\right)$ versus depth to top of gas pool, Uinia Basin, Utah.

metagenesis. However, mixing of some isotopically lighter methane of either bacterial or early thermogenic origin have resulted in the isotopically lighter gas.

Johnson and Rice (1990) interpreted the gases in Paleocene Fort Union and Paleocene and Eocene Wasatch Formations in the adjacent Piceance basin to have had a similar origin as Tertiary gases at Natural Buttes field. There, the Tertiary gases were generated from type III kerogen in the nonmarine part of the Mesaverde and migrated along fractures into shallower, immature reservoirs.

\section{Altamont-Bluebell Field Gas}

The Altamont-Bluebell field produces major quantities of oil from fractured lacustrine and associated facies of the Green River Formation in the northern part of the basin where Tertiary rocks experienced greatcr burial (figs. 6, 7 and 23). Associated gas samples were collected from reservoirs of the Green River Formation at depths of 10,984 to 16,887 feet; these are the deepest gas samples collected for the study (fig. 36). Although the samples occur at these 


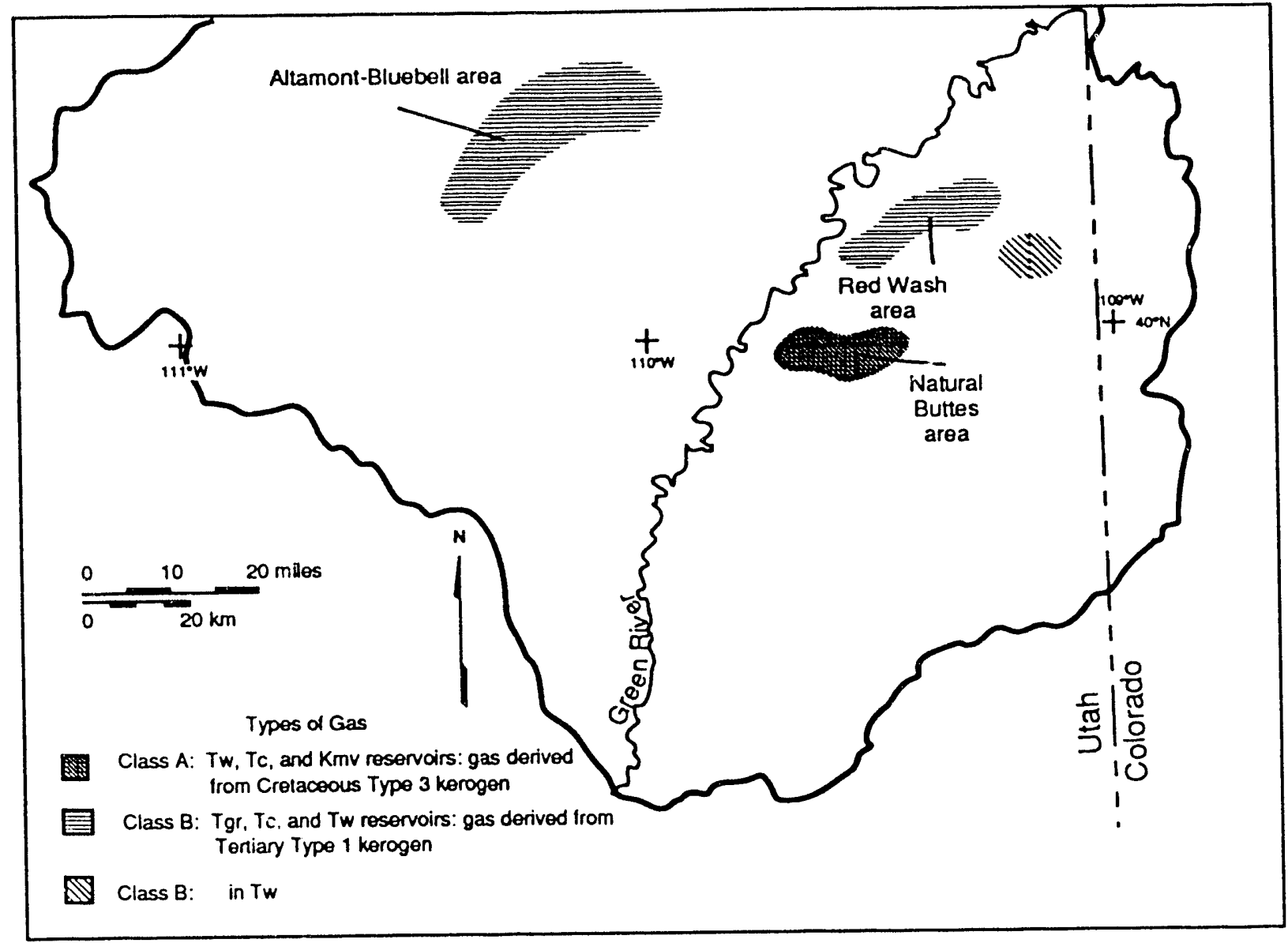

Figure 37. Map of Uinta Basin showing chemical classes of gas and their host formations for fields for which analyses are available. Tw is Wasatch Formation; Tc is Colton Formation; Kmv is Mesaverde Group; Tgr is Green River Formation. Class B gas is commonly associated with oil.

depths, they are associated with oil and are chemically wet and isotopically light, as compared to those just described from the Natural Buttes field (fig. 35 and 36). Based on their composition and on studies by Sweeney and others (1987), the gases are interpreted to have been generated from type I (lacustrine) kerogen in the oil generation window (catagenesis). Sweeney and others (1987) predicted that oil generation from type I kerogen in the area occurs (ed) at depths of about 9,000 to $14,000 \mathrm{ft}$ based on heating values calculated from their geologic model.

\section{Red Wash Field Gas}

In the Red Wash field (figs. 2, 7,21, and 22), both oil and associated gas are produced from the Green River Formation. The producing and adjacent sourcerock facies are lithologically similar and about coeval, but the depth of production (fig. 21, 22, and 36) and levels of thermal maturity (immature to marginally mature) are much less than at Altamont-Bluebell. The gases from reservoirs of the Green River at Red Wash are similar in isotopic composition to those at AltamontBluebell, but are chemically dryer (fig. 36). The gases are interpreted to have been generated from type I kerogen in the Green River Formation in the deeper, more mature part of the basin and to have migrated laterally, along with the oil, into the Red Wash area. This migration resulted in the gases becoming enriched in methane (Schoell, 1983).

\section{MINERALOGY AND DIAGENESIS OF RESERVOIRS}

\section{Sandstone Composition and Reservoir Quality}

Several hundred thin sections of presumed lowpermeability reservoir sandstones Late Cretaceous and early Tertiary in age from the Uinta Basin were point counted ( 300 counts per section) to determine their detrital and authigenic mineral compositions and to relate these features to their overall reservoir quality 
(table 3). Each section was stained to distinguish ironbearing from non iron-bearing carbonate and to aid in the recognition of potassium feldspar. Samples were collected from wells in four areas of the basin: the Natural Buttes, Pariette Bench, Red Wash, and Altamont-Bluebell fields (fig. 2). Each area has undergone a different burial and diagenetic history which has resulted in variable reservoir quality. In general, potential reservoir rocks throughout the basin have low porosity and matrix permeability except Red Wash ficld which is typified by higher porosity and permeability because of its shallow-burial depths. Data from conventional reservoir rocks at Red Wash field are discussed only briefly; they were included in the study because they provide insight into the original reservoir conditions that may have existed in an area of the basin that was never deeply buried. The Altamont-Bluebell ficld also is somewhat atypical because it is extensively fractured and has produced large amounts of liquid hydrocarbons via a well-developed interconnected fracture system that pervades otherwise tight rocks. Analysis of reservoir quality in these strata is important because they are the most deeply-buried rocks in the region, thus, their reservoir characteristics should be in sharp contrast to those in less decply-buried strata. Comparable mineralogic data were collected for rocks of the same age and origin exposed in the Book Cliffs along the south flank of the basin but they only indirectly relate to reservoir quality in the subsurface, thus they will not be referred to in this portion of the study. A wide spectrum of mineralogic and petrophysical data from areas of the basin that have experienced different diagenetic and burial histories should eventually lead to the development of a model that can be used to predict areas of the basin that have specific reservoir characteristics.

Upper Cretaceous and Tertiary sandstones of interest in this study generally are fine-grained and poorto medium-sorted although some medium-grained, well-sorted beds occur locally in some sections. The grain sizes and sorting of individual beds vary significantly within and between localities because of differences in depositional environment and source area (figs. 4 and 6). Based on the classification scheme of Folk (1974), low-permeability Tertiary sandstones in the Uinta Basin display a wide range in composition as shown in figure 38 . The data generally cluster into three distinct groups: a quartz-lithic petrofacies, a quartzose petrofacies, and a feldspathic-lithic petrofacies. Each of these facies spans a broad stratigraphic interval ranging from Late Cretaceous through early Tertiary in age. The quartz-lithic petrofacies, composed predominantly of monocrystalline quartz and sedimentary lithic fragments, comprises litharenites and sublitharenites in the Upper Cretaccous Blackhawk Formation, Neslen Formation and the parts of the lower Tertiary Wasatch and Green River Formations that are geographically restricted to the northern and eastem parts of the basin. Quarzarenites of the quartzose petrofacies typify the Upper Cretaceous Bluecastle Tongue of the Castlegate Sandstone and they form distinct beds that are intercalated with quartz-lithicrich strata of the Wasatch and Green River Formations in the northem and eastem areas of the basin. The feldspathic-lithic petrofacies consists of approximately subequal amounts of sodium and potassium feldspar, a sedimentary lithic assemblage, and a minor component of metamorphic grains. This compositional range, classifying mostly as lithic arkoses and feldspathic litharenites, characterizes sandstones in the Upper Cretaceous undifferentiated Tuscher and Farrer Formations, Price River Formation, and the lower Tertiary Wasatch, Colton, and Green River Formations that extend throughout much of the central and southem parts of the basin. The spatial and temporal distributions of these petrofacies with respect to stratigraphic age and location within the basin are shown on figures 39 and 40.

Sedimentologic and palcoflow characteristics of individual petrofacies are highly variable across the basin inferring sediment contributions from source areas that were tectonically active at different times in the basin's history. Cretaceous quartzose and quariz. lithic-rich sandstones comprise detritus reworked from the thrust belt in westem Utah (fig. 41). In contrast, Tertiary sandstones with essentially the same mineralogies are interpreted to have had a sediment source in the Uinta Mountains, a region that was tectonically active during the Paleocene and Eocene. At about the same time, rising Laramide highlands to the south of the basin contributed feldspar-rich sediment from eroded Cretaceous rock to river systems that flowed northward into the basin. These sediments were redeposited as a thick Tertiary section.

\section{Detrital Constituents in Cretaceous and Tertiary Rock}

Monocrystalline quartz is a major detrital constituent in the three petrofacies types. Grains range from angular to subrounded in shape and from very-fine to medium-grained in size.

Feldspar is a major component in sandstones comprising the feldspathic-lithic petrofacies. Plagioclase and potassium feldspar, the most common varicties, occur in subequal amounts and vary in appearance. 


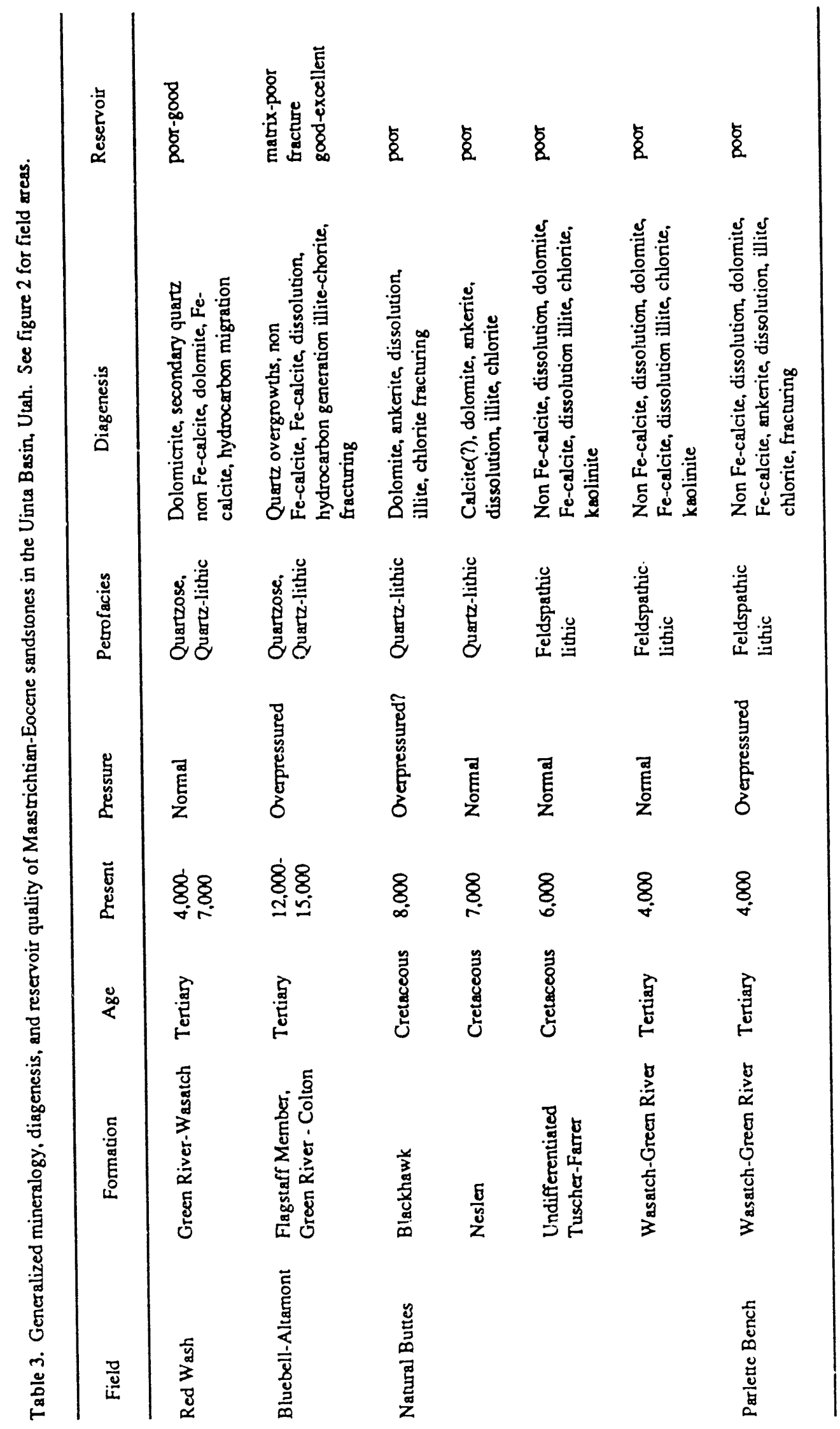




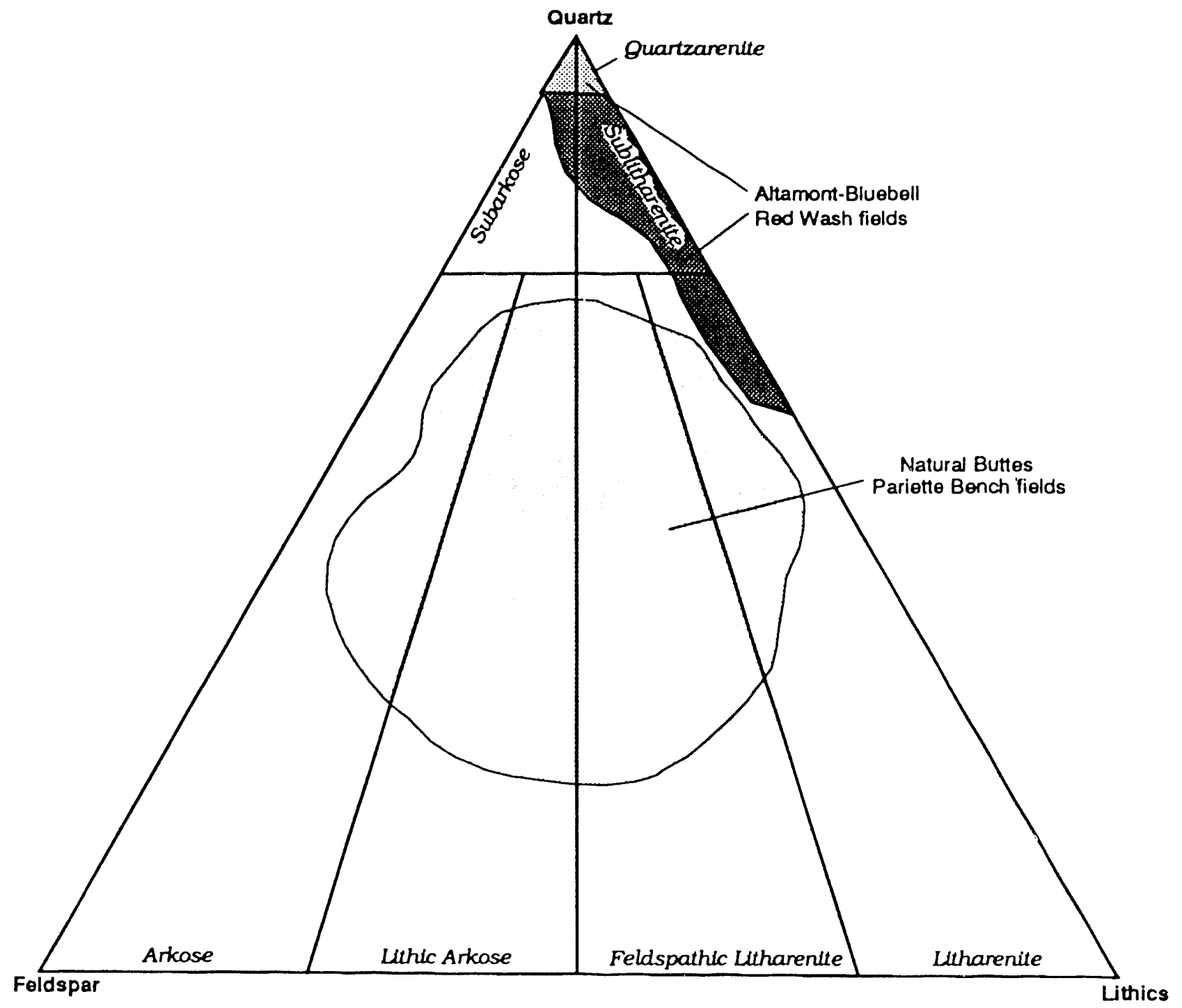

Figure 38. Ternary diagram of petrologic constituents within Tertiary units in the Pariette Bench, Altamont-Bluebell, Natural Buttes, and Red Wash fields. Seefigure 2 for locations of producing areas and figures 4, 5, 6, and 7 for stratigraphic identity of reservoir units.

from fresh to highly altered. The most common alteration features are seritization, carbonate replacement, and dissolution.

Sedimentary rock fragments are dominant constituents in the quartz-lithic and feldspathic-lithic petrofacies. Chert is generally most abundant with lesser amounts of mudstone, shale, and carbonate clasts. Individual grains of chen typically have retained their original size and shape, unlike argillaceous sedimentary rock fragments that have been mechanically deformed to pseudomatrix. Where these disaggregated fragments are widespread, they have significantly decreased the permeability. Other lithic constituents observed include minor metamorphic and plutonic grains and, in feldspathic-rich rocks, rare volcanic fragments all of which are relatively unaltered and did not affect the overall reservoir potential.

Depositional matrix, composed of allogenic clay, is common in low-permeability sandstones in both petrofacies. Because of its extreme fine nature, it tends to obstruct fluid flow thereby inhibiting both cementation and the development of secondary porosity.

\section{Diagenetic Alteration}

The quarz-lithic and feldspathic-lithic petrofacies each show a unique set of diagenetic characteristics that can be related to detrital grain composition and burial history. The extent of alteration within a facies is variable and can account for the differences in 


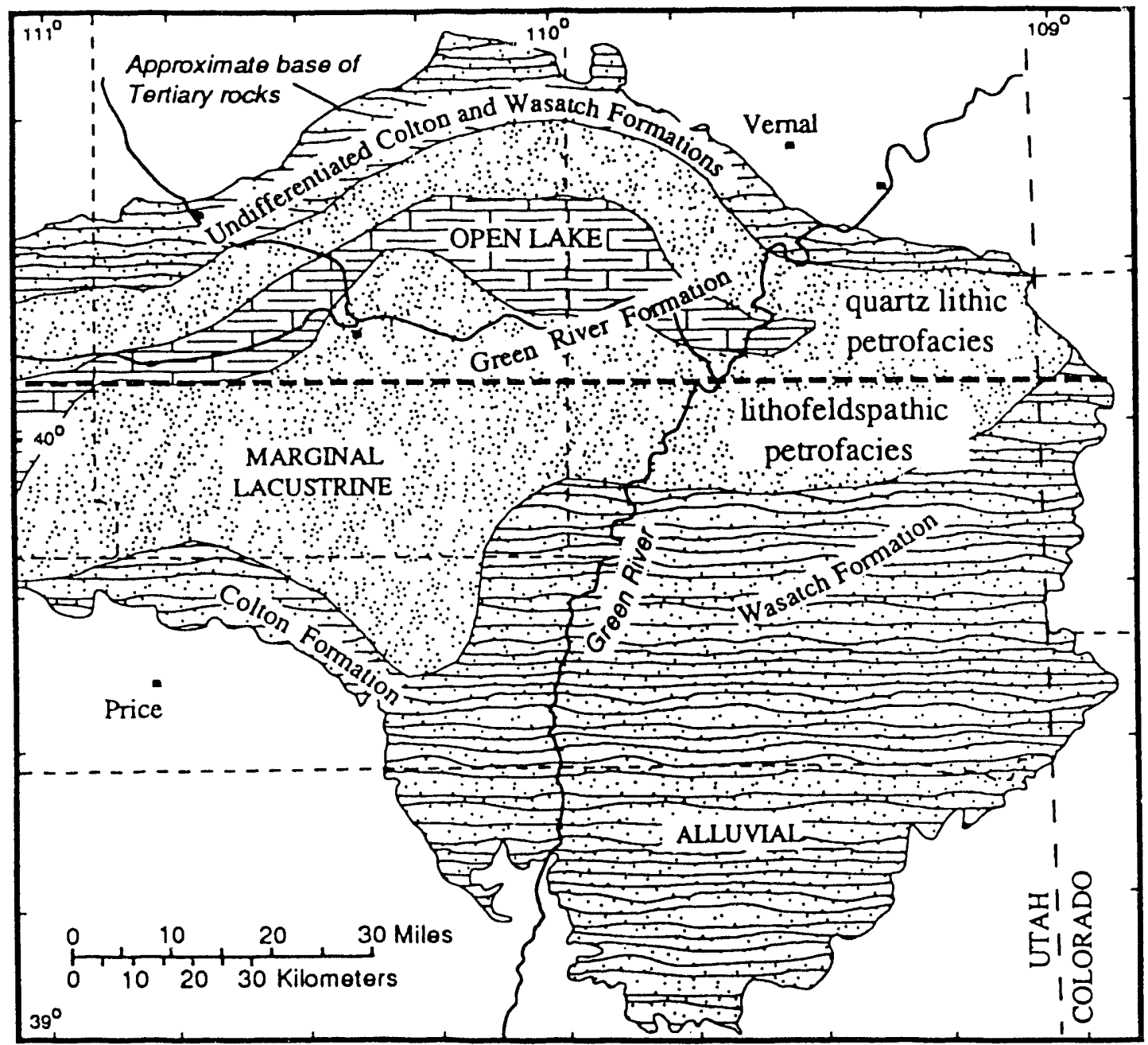

Figure 39. Depositional-facies map also showing distribution of petrofacies for rock in a zone consisting of beds adjacent and laterally equivalent to the middle marker of the Green River Formation (modified from Fouch, 1975). Horizontal dashed line near $40^{\circ} \mathrm{W}$. latitude represents the approximate boundary between the two petrof acies types and reflects nor th and south sediment sources. This map generally characterizes petrofacies for Tertiary strata between the middle marker of the Green River Formation and the boundary between Cretaceous and Tertiary rocks. See figure 5 for position of stratigraphic markers and figure 40 for stratigraphic units in cross-sectional view.

reservoir quality of rocks similar in age but at different localities in the basin. In the feldspathic-lithic petrofacies and, to a lesser degree, the quartz-lithic petrofacies, authigenic cementation, replacement, and dissolution are the primary postdepositional processes that modified reservoir sandstones. Of these processes, cementation and dissolution reactions were the most important with respect to reservoir quality.

Diverse authigenic mineral phases distinguish quarz-lithic from feldspathic-lithic sandstones. In the Sevier thrust belt-derived quartz-lithic sandstones, secondary quartz and dolomite-ankerite cements are most common although they are present in relatively small amounts due to the presence of widespread matrix and mechanically unstable lithic fragments which disaggregated eliminating most of the initial pore space early in the burial history. Authigenic clay minerals are difficult to recognize because of the absence of porosity; however, much of the detrital matrix, particularly in the deeper-buried rocks, probably recrystallized to a well-ordered 10 angstrom clay. Diagenetic modification tends to be more diverse in the feldspathic-lithic petrofacies reflecting the presence of different compositional types of feldspar. The major authigenic components in these rocks include a complex carbonate assemblage and a variety of clay minerals. Combined, these constituents significantly affected the reservoir quality of an individual bed or series of beds depending their burial history. Minor authigenic phases such as quartz, anhydrite, barite, arıd pyrite are present in some rocks but generally they did not significantly affect the reservoir quality of the sandstones. 


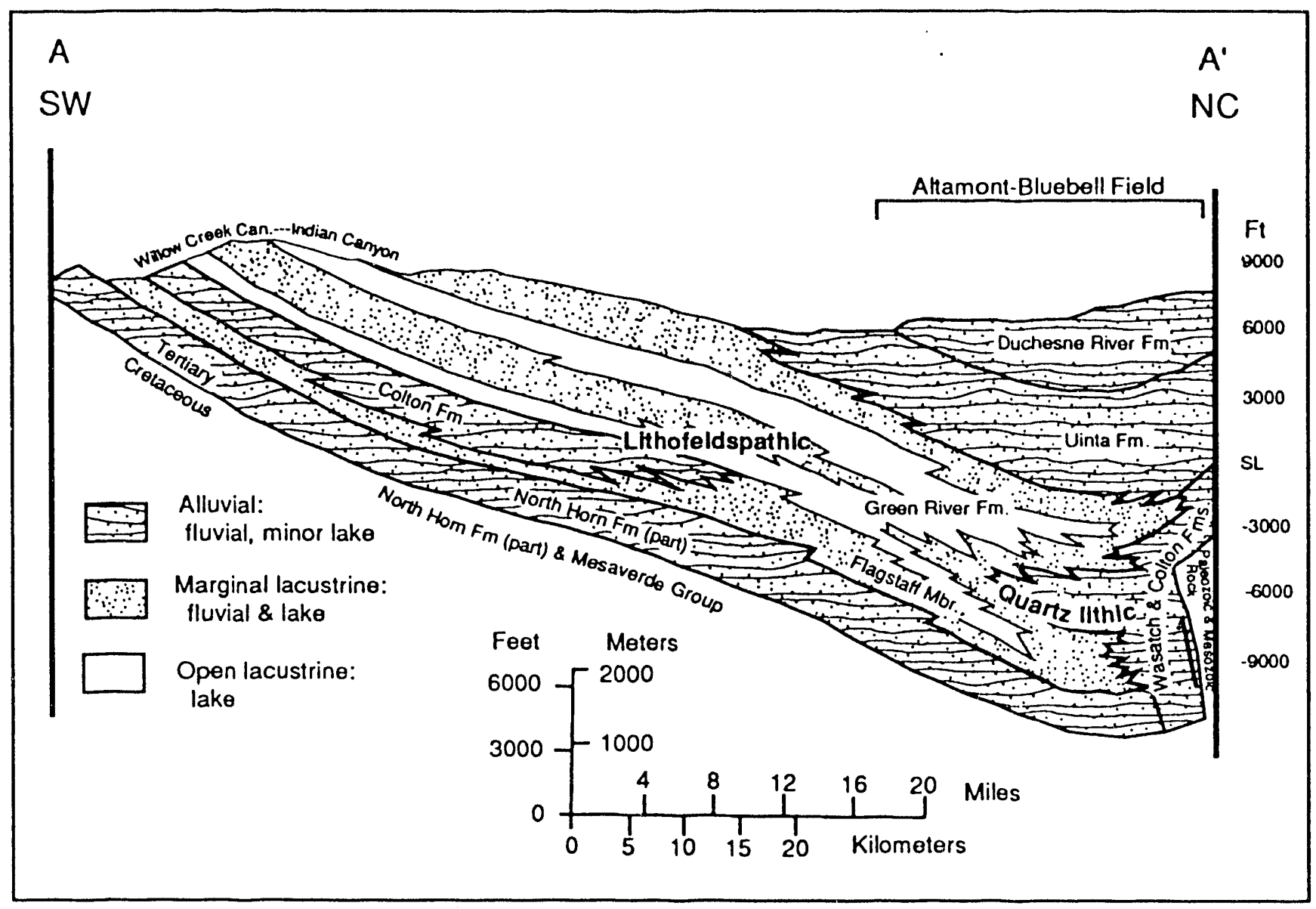

Figure 40. Cross section A-A' of Tertiary rocks extending from Willow Creek-Indian Canyon to the Altamont-Bluebell field area showing principal petrofacies. See figure 3 for line of section, figure 6 for stratigraphic position of producing intervals. and figure 39 for map view of petrofacies projected into a map of the middle marker zone.

\section{Carbonate Phases}

Multiple generations of carbonate consisting of calcite, ferroan-calcite, dolomite, and ferroan-dolomite are observed in Cretaceous and Tertiary sandstones reflecting a multistage diagenetic history. Calcite and ferroan-calcite are the dominant carbonate phases in feldspathic-lithic sandstones and in the Uinta Mountain-derived quartz-lithic rocks; they are present in variable amounts at all depths studied. In contrast, dolomite and ferroan-dolomite are most abundant in the Sevier-thrust belt derived quartz-lithic sequence. The amount and distribution of authigenic carbonate phases within and between beds may be widespread or localized depending on the depositional environment and the burial history of different areas of the basin. Where carbonate phases are well-developed, they typically form a poikilotopic cement that fills pores and partly to completely replaces fresh to slightly altered detrital framework grains. If carbonate is minor, it usually is distributed as discrete grains or as irregular patches.
Petrographic analysis reveals the sequential order of carbonate formation in sandstones to be calcite, dolomite, ferroan-calcite, and ferroan dolomite. Calcite, distinguished by its red stain, occurs most commonly as small patches that are partly replaced by ferroan-calcite (identified by its purple stain). The embayed texture of non-ferroan calcite relicts in pores suggests this carbonate phase was affected by dissolution early in the diagenetic history. Ferroan-calcite is a pervasive cement at greater burial depths although it also may occur as a patchy cement implying a subsequent episode of leaching during late stage diagenesis. In some reservoir sandstones, porosity enhancement as a result of ferroan calcite leaching may be well-developed; however, these zones of high porosity are usually isolated and volumetrically insignificant because of the lenticular nature and complex geometry of individual beds. Like calcite, dolomite exits as isolated grains and small patches of cement but it also may replace matrix. Individual dolomite grains are angular to partly abraded in shape and often contain a euhedral ferroan rim. Some carbonate grains may have served 


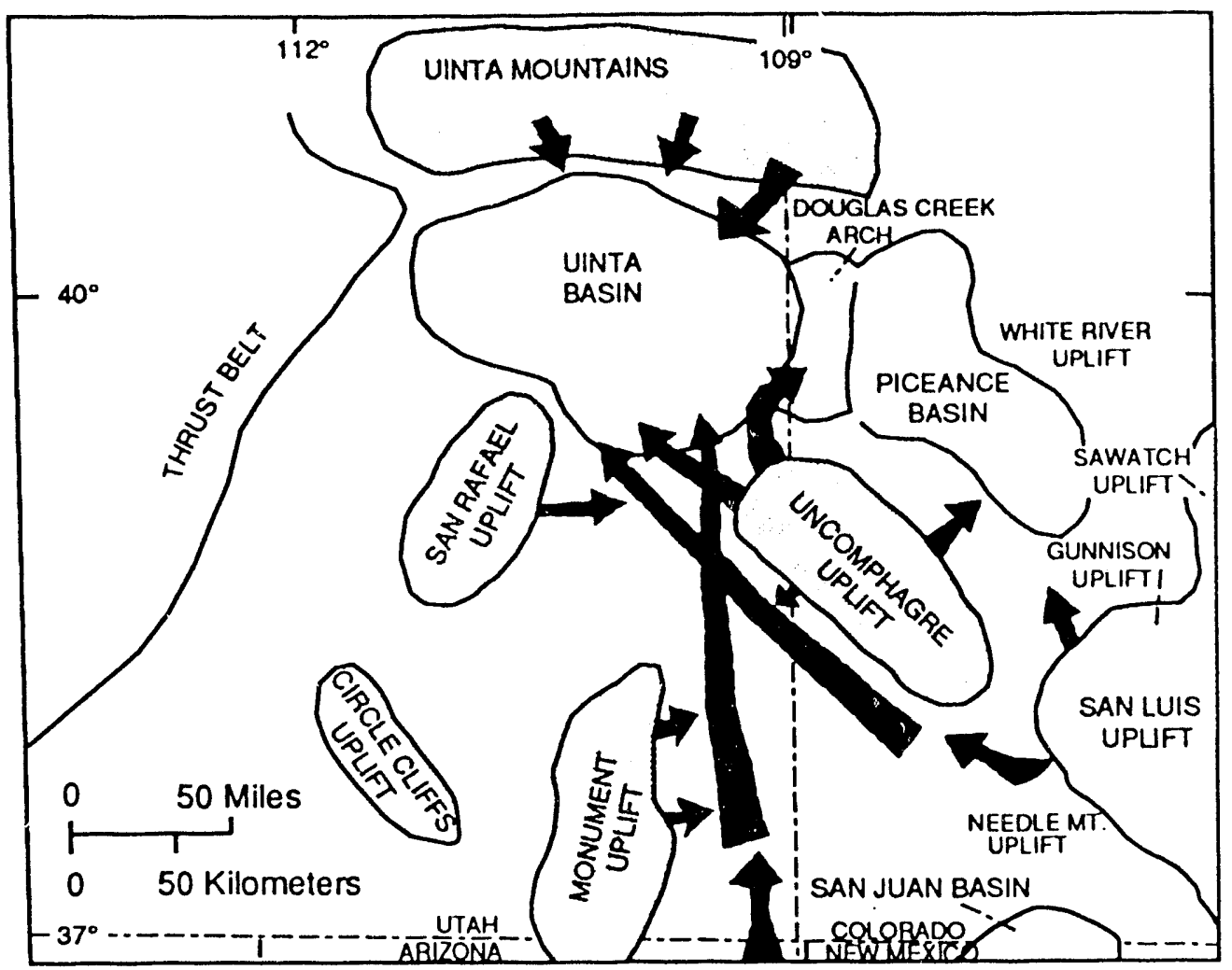

Figure 4I. Map of eastern Utah and western Colorado showing major structural elements that existed at some period in Late Cretaceous and early Tertiary time and that contributed sediment to the area of the central and eastern Uinta Basin. Utah.

as nucleation sites for later ferroan carbonate cement. Ferroan dolomite recognized by its dark blue stain occurs both as discrete rhombs and as pore-fill and replacement cement that shows no evidence of leaching. It is most abundant in deeper-buried rocks in the basin.

\section{Authigenic Clays}

Authigenic clay minerals in reservoir sandstones consist of kaolinite, chlorite, illite, and interstratified illite-smectite. In the Sevier thrust belt derived quartzlithic sandstones, the major clay-mineral assemblage is composed of illite, illite-smectite, chlorite, and rare kaolinite. The 10-14 Angstrom minerals, which commonly occur together in the same bed, represent products related to the recrystallization of matrix and associated argillaceous material during burial diagenesis. Generally, the same suite of clay minerals comprises the feldspathic-lithic petrofacies but in different proportions. Kaolinite is dominant in most sandstones with lesser yet significant amounts of illite, illitesmectite, and chlorite. Rare corrensite occurs locally in some sequences. Petrographic analysis shows kaolinite distributed as stacked hexagonal crystals that fill secondary intergranular pores and voids within framework grains such as feldspar that were created by the dissolution of carbonate. Fibrous authigenic illite and randomly-oriented platelets of chlorite often are distributed along framework grain surfaces and are in contact with kaolinite that fills the center of a pore. Where these minerals are abundant, they can significantly affect the reservoir quality of the host sandstone.

Illite and kaolinite in feldspar-ricl rock exhibit a spatial zonation pattern across the basin. Kaolinite is conspicuously absent in Teriary quartz-lithic rich rocks with high primary porosity and permeability along the eastem flank of the basin. This lack of occurrence can be attributed to the lack of feldspar as a dominant framework-grain constituent. However, kaolinite is abundant in temporally-equivalent strata and in older Cretaceous rocks at Natural Buttes field to the southwest. To the west, in the vicinity of Pariette Bench field and along the northern flank of the basin at AltamontBluebell field, kaolinite is absent in Tertiary age rocks and illite is the major clay phase. The transition from a kaolinite-dominated clay assemblage in the distal part of the basin to an illite-dominated sequence in the proximal and deeply-buried portions of the basin is interpreted to record the evolution of formation waters 
from relatively fresh conditions near recharge areas to reducing conditions in the deeper, more restricted parts of the section.

\section{Secondary Quartz}

In both petrofacies, rare authigenic quartz occurs as small, poorly-developed overgrowths on detrital grains, usually in sandstones that are relatively free of labile lithic grains and matrix and that contain abundant detrital quarz. The abraded nature of many overgrowths may be indicative of detrital grain and grain overgrowths reworked from the source area to the site of deposition. The volumetrically minor amount of sccondary quartz in most Cretaceous and Tertiary sandstones implies that it was not an important factor controlling the distribution of porosity.

\section{Other Diagenctic Phases}

Petrographic analysis reveals local occurrences of anhydrite and barite as a replacement mineral in some sandstones in the feldspathic-lithic petrofacies.

\section{Petrophysical Properties of Sandstone Bodies}

The reservoir quality of Cretaceous and Tertiary sandstones in the Uinta Basin was evaluated based on measured ambient and in-situ porosity and permeability valucs and visible porosity measurements determined by petrographic analysis. As expected, most sandstones show a significant decline in reservoir quality with increased burial and thermal maturity. A similar burial-related trend characterizes permeability although the variability between individual samples is not as great as that for porosity.

The dominant porosity type in reservoir rocks is rclated largely to depth of burial. For example, primary intergranular porosity is a major feature in shallowburied rocks ( $<4,000 \mathrm{ft})$ along the eastem margin of the basin. However, in more deeply-buried rocks, the initial porosity was reduced during diagenesis by mechanical compaction of unstable grains and precipitation of mineral cements. Volumetric determinations of authigenic cements in these rocks indicate original porosities between 30 to 40 percent. The dominant porosity type at depths greater than about $4,000 \mathrm{ft}$ is secondary porosity which resulted from partial dissolution of intergranular carbonate cement and carbonate-replaced framework grains such as feldspar.

The nature and extent of porosity develnpment in Cretaccous and Tertiary reservoir sandstones are a function of mineralogic composition, clay content, mean grain size, sorting, framework-grain compartion, and development of authigenic mineral cements. Detrital mineralogy and, to a lesser extent, grain size vary across the basin which, combined with the effects of burial and a complex cementation-dissolution history, result in highly variable porosity values. Except in shallow-buried Tertiary rocks along the eastem margin of the basin, the quartz-lithic petrofacies generally displays the least amount of porosity due to abundant sedimentary lithic fragments squeezed into the original pore space. However, in the feldspathic-lithic petrofacies, porosity is highly variable because of multiple episodes of carbonate cementation and dissolution. In some feldspathic-rich sandstones, carbonate cementation is pervasive while others show localized carbonate occurrences along with evidence of widespread carbonate dissolution preserved as secondary porosity. A moderately stable mineral assemblage is necessary to preserve good reservoir quality in the decper subsurface. If some fraction of the mechanically and chemically unstable grains are feldspar, the development of secondary porosity is favored because they dissolve. However, if the percentage of these grains becomes to high or the fraction is dominated by argillaceous fragments that form pscudomatrix, as is the case in many feldspathic-rich sandstones, porosity ultimately will be greatly reduced. Kaolinite, illite, and chlorite also tend to be widespredd in feldspar-rich sandstones filling secondary pores which leads to decreased porosity and permeability. Moreover, the large surface areas of clay minerals such as kaolinite and to a lesser extent chlorite promote high water saturations which can create problems during reservoir stimulation. In addition, fibrous illite and mixed-layer clays block pore throats which restrict fluid movement through the system.

\section{Regional Trends in Reservoir Quality}

Generalized mineralogic, diagenetic, and reservoir properties of Cretaceous and Tertiary sandstones in four areas of the basin are summarized in table 3 and figure 42. Except for Paleocene and Eocene rocks (Wasatch, Colton Green River, Formations), stratigraphically and temporally equivalent intervals generally were not cored at different geographic localitics. Thus, spatial comparison of reservoir quality between rocks of the same age and origin that experienced different depositional and burial histories is limited. However, given that only three petrofacies types distinguish Cretaceous and Tertiary strata throughout most of the basin, and the fact that the burial history of the region is fairly well constrained, it may be possible 


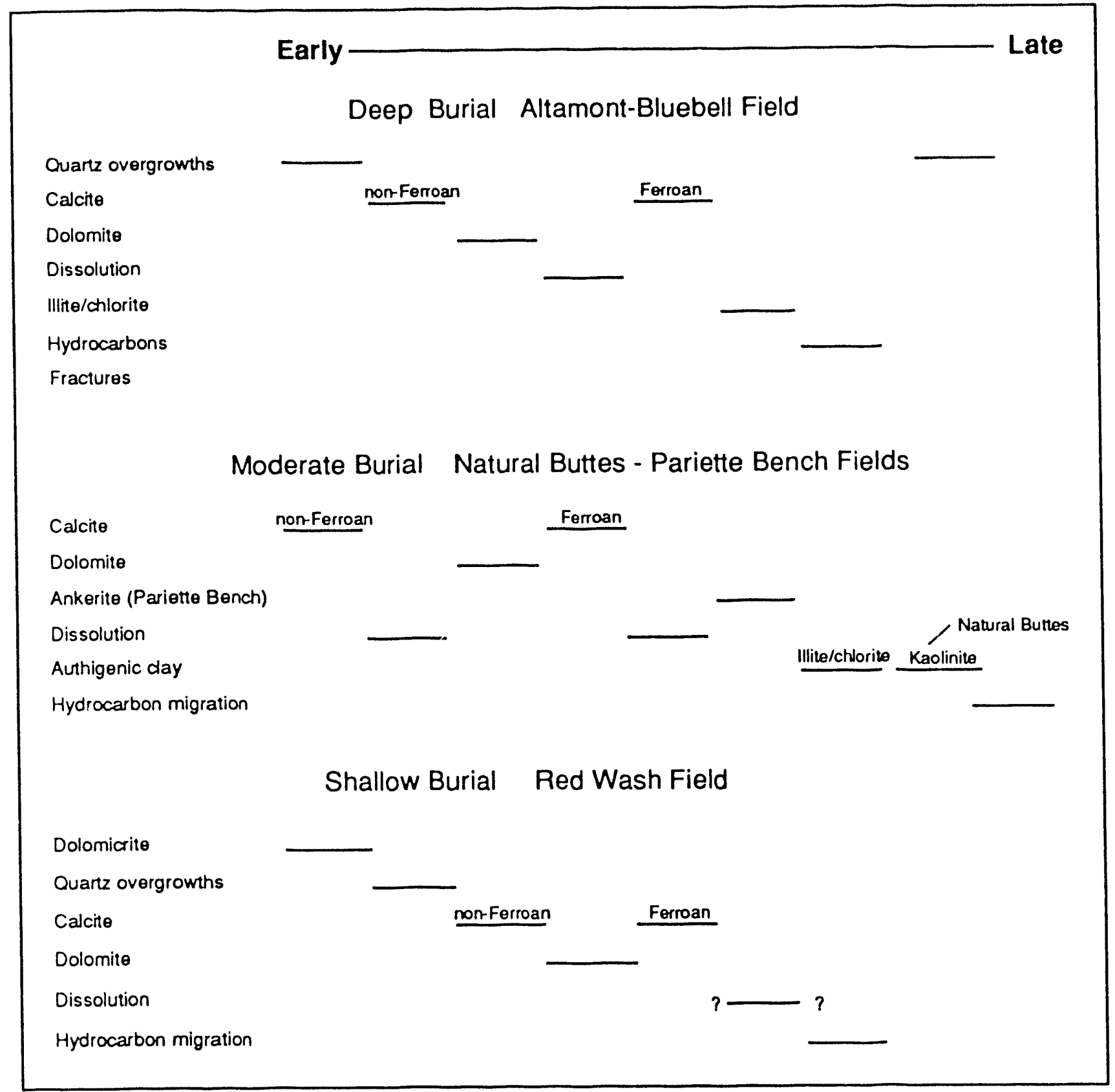

Figure 42. Sequence of diagenetic events related to hydrocarbon migration in the Altamont-Bluebell, Natural Buttes, Parielle Bench, and Red Wash fields.

to predict with some degree of accuracy the nature and extent of the major diagenetic reactions that occurred both temporally and spatially as well as their affect on reservoir potential. A description of shallow-to deeplyburied rocks in the four areas of the basin along with a discussion of the reservoir quality is given below.

\section{Mineralogy and Diagensis of Red Wash Reservoirs}

In the northeastem part of the basin, the Paleocene and Eocene Wasatch and Green River Formations have produced significant hydrocarbons from conventional reservoirs in Uinta Mountain-derived quartz-lithic and quartz-rich sandstones and fossiliferous carbonate rock. Paleoenvironmental studies indicate that conventional and unconventional units in the field represent a broad range of lacustrine depositional settings varying from fluvial-deltaic systems to barrier-beach complexes (Castle, 1990). These rocks which lie at burial depths between 4,000 to 7,000 ft (?) typically have relatively high matrix porosities (13-15 percent) and permeabilities (75-125 md) compared to temporally equivalent units that lie farther west and north in the basin (Chatfield, 1972). Palcogeographic reconstruc- 
tion indicates Wasatch and Green River strata reached their maximum burial depths and temperatures about $20 \mathrm{Ma}$ (Early Miocene) followed by minor uplift and crosion at about $10 \mathrm{Ma}$ (Late Miocene) (Pitman, unpublished data; Chevron Oil Co., unpublished data). That these rocks were never deeply buried is supported by petrographic data which shows preservation of a well-developed primary pore-network in many sandstones.

Shallow-buried, quartz-lithic-rich and quarzose sandstones in the Wasatch and Green River Formations in Red Wash field (figs. 21 \& 22) are important to study because they exhibit less complex diagenetic modifications than more-deeply buried time-equivalent lithic-feldspathic sandstones in the eastem and central parts of the basin. For example, some quartzarenites show primary porosity occluded by poikilotopic ferroan and non-ferroan calcite cement with minor secondary quartz overgrowths and dolomicrite cement whereas other sandstones display a well-developed primary pore network that is open or partly filled with dolomicrite, euhedral quartz overgrowths, or bituminous residue. Authigenic clay minerals are virtually absent in sandstones that have good primary porosity. Local occurrences of bitumen and minor authigenic mineral phases in porous and permeable sandstones are taken as evidence that hydrocarbons migrated into reservoir sandstones early in the burial history. The emplacement of hydrocarbons during early burial prevented further sandstone alteration thus preserving the porosity and permeability present at the time of reservoir charging. The positive correlation between hydrocarbon occurrence and good reservoir quality does not exist elsewhere in the basin except locally at Pariette Bench field where there is geochemical evidence of early migrated oil.

\section{Mineralogy and Diagensis of Altamont-Bluebell Reservoirs}

The Altamont-Bluebell field, located along the structural axis that parallels the north flank of the basin, has produced large amounts of hydrocarbons from naturally-fractured rock that otherwise has generally poor reservoir quality. Production typically is from the ovirpressured Paleocene and Eocene Colton, and Green River Formations, including the Flagstaff Member, which are presently at burial depths between 11,000$15,000 \mathrm{ft}$. A burial-history model suggests at least 2,000 ft of Tertiary rock was eroded from the section during Colorado Plateau uplift (fig. 43); at maximum burial the rocks were at depths from 13,000 to 17,000 $\mathrm{ft}$. In the northem part of the basin, the Colton and
Green River Formations consist of fine-grained alluvial and marginal-lacustrine sandstones with mineralogic compositions typical of the Uinta Mountain-derived quartzose and quarz-lithic petrofacies although a few percent plagioclase feldspar exist in some sandstones. The reservoir quality, specifically the matrix porosity, is poor in most sandstones because the rocks have been affected by extreme mechanical compaction and have experienced a more complex diagenetic history due to deep burial. The major authigenic cements are secondary quartz overgrowths, ferroan and nonferroan calcite, and dolomite. Ferroan dolomite occurs very rarely and the clay minerals illite and chlorite are present sporadically in variable amounts. Combined, these minerals have greatly reduced the reservoir quality of the sandstones.

Core-plug petrophysical data for reservoir sandstones in the Colton and Green River Formations are not available for the wells analyzed in our study . However, measured visible porosity data obtained by petrographic analysis is highly variable, from 0 to 24 percent, although generally it averages less than 5 percent. Most porosity is secondary intergranular that formed as a result of carbonate dissolution based on remnant carbonate grains in voids. A few sandstones show minor porosity that is interpreted to be primary because there is no evidence of pre-existing carbonate.

Parallel, near vertical, open to partly mineralized fractures are abundant in the Colton and Green River Formations and greatly affect the reservoir quality. The mineralized portions of fractures typically are cemented with quartz and carbonate minerals both of which contain oil inclusions (Narr and Currie, 1982). Fractures increase the interconnection between isolated pore, thereby increasing the overall effective porosity and permeability in these rocks. Permeability associated with matrix in reservoir sandstones is assumed to be very low based on the mineralogic characteristics; however, fracture permeability is generally high and is an important factor regarding production in the field.

\section{Mineralogy and Diagenesis of Natural Buttes Reservoirs}

The factors controlling the reservoir quality of low-permeability rocks in the eastem Uinta Basin were evaluated by studying cored stratigraphic intervals in the Upper Cretaceous Blackhawk, Neslen, and undifferentiated Farrer and Tuscher Formations, and the upper Paleocene and Eocene Wasatch Formation (fig. 24). The rocks in these units represent a wide range of depositional regimes: marine near-shore to 


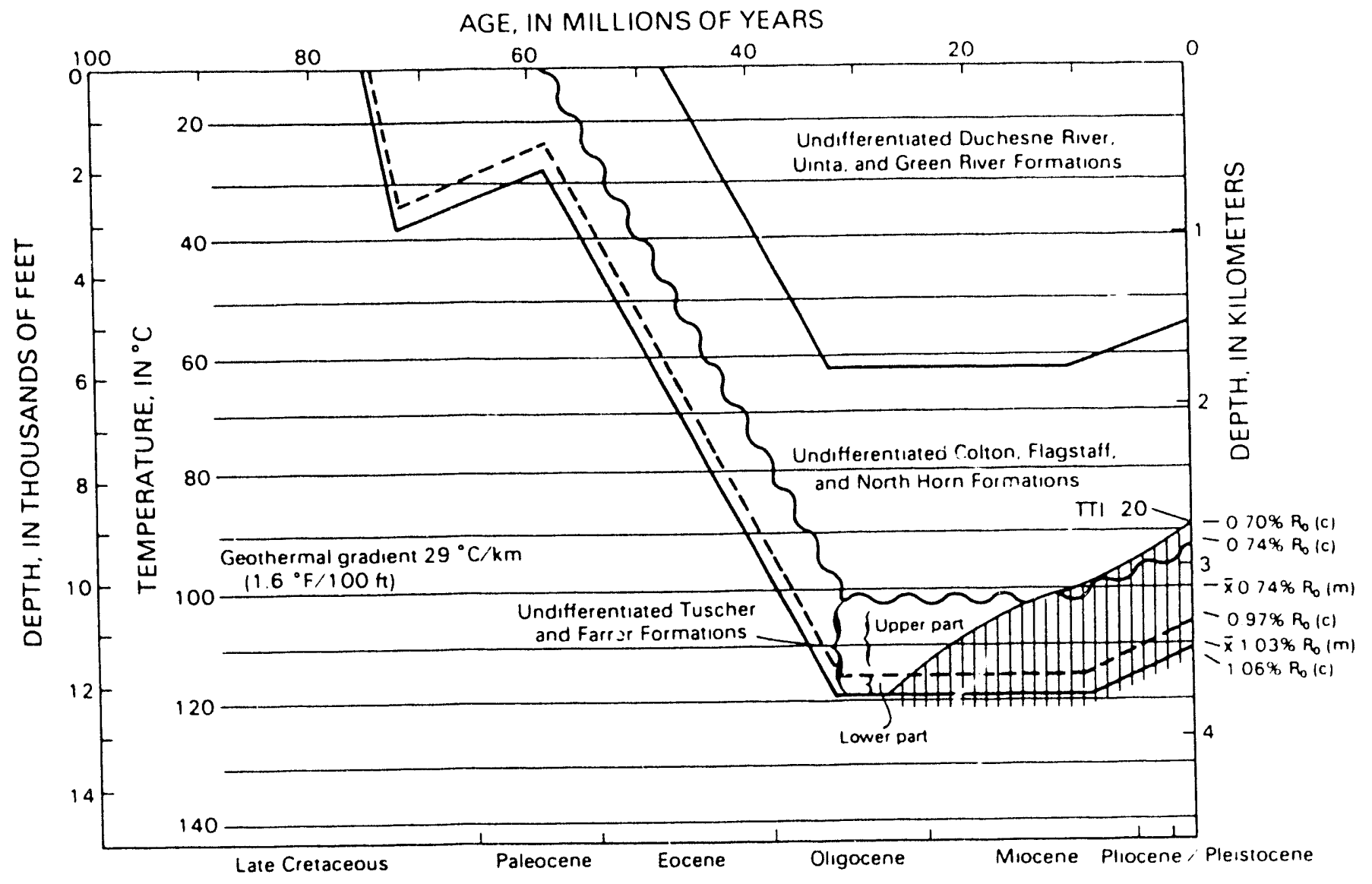

Figure 43. Modified Lopatin model showing reconstructed burial and thermal history of Cretaceous and Tertiary rocks in south-ceniral and eastern Uinta Basin. Isotherms show past and present geothermal gradient; wavy line indicates Cretaceous-Tertiary boundary; dashed line depicts projected present ground-surface level; patterned area is zone of

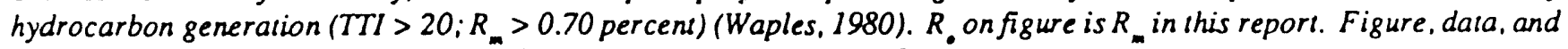
explanation of information are modified from Pitman and others. (1987).

backshore environments in the Blackhawk Formation, nonmarine coastal and lower alluvial-plain settings in the Neslen Formation, alluvial braidplain and overbank environments in the undifferentiated Farrer-Tuscher Formations, and lower delta-plain settings in the Wasatch Formation Detailed sedimentologic and lithologic descriptions of these units are given in Pitman and others $(1986 ; 1987)$. The reconstructed burial and tectonic history of the area (fig. 43) reveals that Upper Cretaceous and Tertiary rocks at Natural Buttes reached maximum burial during the Oligocene and Miocene and then were uplifted and eroded from 10 Ma to the present during the development of the Colorado Plateau. Approximately 3,000 ft of Tertiary section are estimated to have been eroded from the section at that time (Pitman and others, 1987). Cretaceous and Teriary strata at Natural Buttes now are at burial depths between 4,000 and 8,000 ft and analysis of available drill-stem test data indicate that they are normally pressured (fig. 26).
Diagenetic features preserved in Upper Cretaceous and Tertiary rocks record changes in the burial and thermal history with time. The quartz-lithic petrofacies typifying the Blackhawk and Neslen Formations was modified by mechanical deformation of unstable lithic grains, the precipitation of silica cements as quartz overgrowths during shallow burial, cementation and framework grain replacement by dolomite, ankerite, and barite during deep burial, dissolution of unstable lithic fragments during deep burial, and development of authigenic clay minerals throughout the burial history. A similar paragenetic sequence was documented for the Neslen Formation in Southman Canyon field a few miles to the west (Keighin and Fouch, 1981). Except for mechanical compaction, the extent of postdepositional alteration in these Upper Cretaceous rocks was relatively minor and did not play an important role in determining their overall reservoir characteristics. 
Diagenetic events that affected the feldspathiclithic petrofacics of the undifferentiated Farrer and Tuscher Formations, and the Wasatch Formation were more extensive than those in older rocks devoid of feldspar. Feldspathic-lithic sandstones have been altered by secondary quartz, multiple generations of carbonate- non-ferroan calcite, ferroan calcite, dolomite, and minor ankerite, local occurrences of anhydrite and barite, and the clay minerals kaolinite, illite, illite-smectitc, chlorite, and corrensite. Comparable authigenic mineral phases have been reported for stratigraphically-equivalent rocks in nearby Southman Canyon ficld (Keighin and Fouch, 1981). Authigenic non-ferroan calcite and dolomite, present in some rocks and absent in others, formed during early burial before significant compaction. Later in the diagenetic history, variable amounts of ferroan calcite precipitated when the rocks were close to maximum burial. An episode of carbonate dissolution also occurred during later stages of diagenesis followed by the subsequent crystallization of anhydrite and barite and illite, illite-smectite, chlorite, and corrensite in secondary pores. Most kaolinite probably formed during late stage uplift and erosion in response to an influx of nearsurface meteoric water that mixed with more reducing waters although it is possible that some fraction of kaolinite in the upper pan of the undifferentiated Farrer and Tuscher Formations may be older and associated with the development of the Cretaccous-Tertiary unconformity (Pitman and others, 1986).

The reservoir quality of Upper Cretaceous and Tertiary rocks at Natural Buttes and nearby areas is influenced by stratigraphic position within a depositional sequence, petrofacies type, and the nature and extent of burial alteration. Porosity preserved in the Blackhawk and Neslen Formations typically is low (210 percent) as is permeability which averages $<1 \mathrm{md}$ (Pitman and others, 1987). Petrographic analysis indicates that porosity in the Blackhawk and Neslen Formations is enhanced in sandstones that contain dissolved framework grains and matrix and is reduced in rocks that exhibit extensive mechanical compaction of unstable framework grains. In the Blackhawk Formation, abundant fossiliferous chert grains commonly are parly dissolved and exhibit microporosity. Rare oversized pores and partly open natural fractures in both formations also contribute to the porosity. Consistently low permeability reflects the abundant matrix and pseudomatrix that characterizes these rocks.

Porosity preserved in the undifferentiated Farrer and Tuscher Formations, and the Wasatch Formation is highly variabie ranging from 0-13 percent and 0-15 percent, respectively (Pitman and others 1986). Dis- similar reservoirquality between individual beds within each formation can be attributed to differences in grain size and sorting and to the relative abundance of individual grain types. For example, in a thick, sandstone-dominated interval, beds with the highest porosity generally are coarser-grained and contain a minor component of matrix but a high percentage of framework grains and intergranular pores containing relict carbonate cement. Initially, reactive fluids migrated through an open, well-developed pore network which resulted in the formation of carbonate replacement and pore-fill cement thus climinating mest primary porosity. During later diagenesis, partial dissolution of carbonate, possibly caused by organic acids relcased during thermal gas generation, enhanced porosity. A second carbonate reduction and enhancement cycle occurred during decper burial resulting in the local occurrences of ferroan calcite and secondary porosity now ebserved in the sandstones. The secondary inter and intragranular pores eventually became occluded by authigenic clay which further decreased the porosity in many sandstones. Upper Cretaccous and Tertiary strata with the lowest porosity usually are fine-grained and more poorly-sorted. Moreover, they commonly contain a larger component of matrix and pscudomatrix which effectively eliminated the original pore space. Authigenic cemenis in these beds tend to be poorly developed.

Permeability in these Upper Cretaceous and Tertiary rocks was most affected by the development of authigenic clay in residual pores. Clay-filled pores exhibit microporosity which tends to be discontinuous thus inhibiting the mo vement of fluids or hydrocarbons through the pore network.

\section{Mineralogy and Diagenesis of Pariette Bench Reservoirs}

The lower part of Eocene strata of the Green River Formation (Douglas Creck Member-figure 6) was penetrated in three wells at Pariette Bench ficld located in the central part of the Uinta Basin. The cored rocks comprise feldspathic-lithic rich, alluvial sandstones interbedded with lacustrine claystones and carbonate rock. These strata are at present-day burial depths between 4,000 and 5,000 ft and are slightly overpressured (Pitman and others, 1982). The rocks may have been buried as much as 3,000 ft deeper in the past. Field studies and time-temperature reconstruction indicate a burial and thermal history similar to that postulated for temporally-equivalent rocks at Natural Buttes field farther to the east. This infers a comparable sequence of diagenetic events in the reservoir sandstones at 
Pariette Bench. However, based on petrographic analysis, more advanced stages of alteration typify the sandstones which strongly suggests that the nature and extent of organic-diagenetic reactions in an overpressured regime differed from those in a normally-pressured environment despite similar burial histories. Minor quartz overgrowths formed early in the burial history followed by non-ferroan calcite, dolomite, ferroan-calcite, and ferroan dolomite (ankcrite) which replaced grains and filled intergranular pores during early and late stages of diagenesis. Relict non-ferroan calcite together with patchy occurrences of ferroan calcite in some sandstones is evidence for early and late stages of calcite dissolution which is preserved as secondary porosity in the sandstones. Well-crystallized ankerite which was not observed in temporally equivalent rocks at Natural Buttes replaces ferroan calcite and locally forms a pore-fill cement that does not show the effects of dissolution. Stable isotope geochemical data of end-member carbonate (Pitman and others, 1982) display an isotopic trend toward more depleted carbon and oxygen values with increased iron content. The evolution in carbonate composition from early low-iron to later higheriron varieties with time is interpreted to reflect progressive diagenesis in a restricted hydrologic regime influenced by high pore-fluid pressures. Multiple episodes of carbonate dissolution probably took place in the same diagenetic regime in response to organic reactions during gas generation. Secondary inter and intragranular pores that resulted from carbonate dissolution typically are filled with illite, illite-smectite, and chlorite which likely formed at about the same time and under the same burial conditions as the iron-cartonates. Apparently, recharge waters near the basin margin did not reach the proximal portions of the basin because kaolinite is absent in these sandstones unlike the rocks at Natural Buttes field to the east where kaolinite is abundant.

Porosity in sandstones of the Wasatch and Green River Furmations in the central part of the basin is highly variable (between 1.2 and 16.2 percent) whereas the permeability is usually less than $.1 \mathrm{md}$ which is characteristic of unconventional reservoir rocks (Pitman and others, 1982). As at Natural Buttes, the highest porosity values occur in sandstones that are coarser-grained and that have the least amount of unstable framework grains and matrix material. At Pariette Bench, sandstones with these characteristics occur at the base of fluvial channel-formed beds which was the high energy part of an overall low-energy depositional system. The relatively high initial porosity in these sediments promoted the formation of authigenic cements which later were locally dissolved creating secondary porosity. Most secondary voids are now occluded with authigenic clay which forms a complex micropore network that results in decreased fluid flow and consequently, low permeability. Sandstones with the lowest porosity values at Pariette Bench field are composed of large amounts of matrix material and unstable framework grains which eliminated most original pore space due to compaction.

\section{POROSITY AND POROSITY PREDICTION}

In some areas of the Uinta Basin, few wells penetrate the nonmarine sandstones of the Mesaverde Group. For this reason, a predictive model for the typical porosity and porosity range of these sandstones is necessary for regional assessment of hydrocarbon resources and reserves.

Predictive porosity trends are developed here as a function of thermal maturity as represented by vitrinite reflectance $\left(R_{m}\right)$ rather than of depth. By plotting porosity against $R_{m}$, which is a measure of timetemperature exposure, effects upon the data of local topographic relief, varying thermal gradients, and regional differences in uplift and erosion are normalized. In addition, porosity change can be placed in the context of hydrocarbon generation if porosity is characterized in terms of $R_{m}$.

\section{Core-Plug Data Set}

Core-plug porosity and $\mathrm{Rm}$ data representing nonmarine sandstones of the Mesaverde Group in 14 wells from 11 widely separated locations in the Uinta and Piccance basins (fig. 44, table 4) are assembled for this study. The scarcity of suitable Mesaverde porosity data from the Uinta Basin dictates that measurements from the Piceance Creek basin be included in the data set. We infer that Piceance samples are applicable because nonmarine rocks of the Mesaverde Group in the Uinta and Piceance Creek basins are temporally and depositionally similar (Keighin and Fouch, 1981). By plotting porosity as a function of $R_{m}$, differences in the subsequent burial and thermal histories of the Uinta and Piceance Creek basins are taken into account and porosity measurements from the two basins can be combined.

The number of porosity measurements representing a cored interval varies (table 4). Instead of plotting these porosity measurements individually, in which case some strata would influence interpretations more 


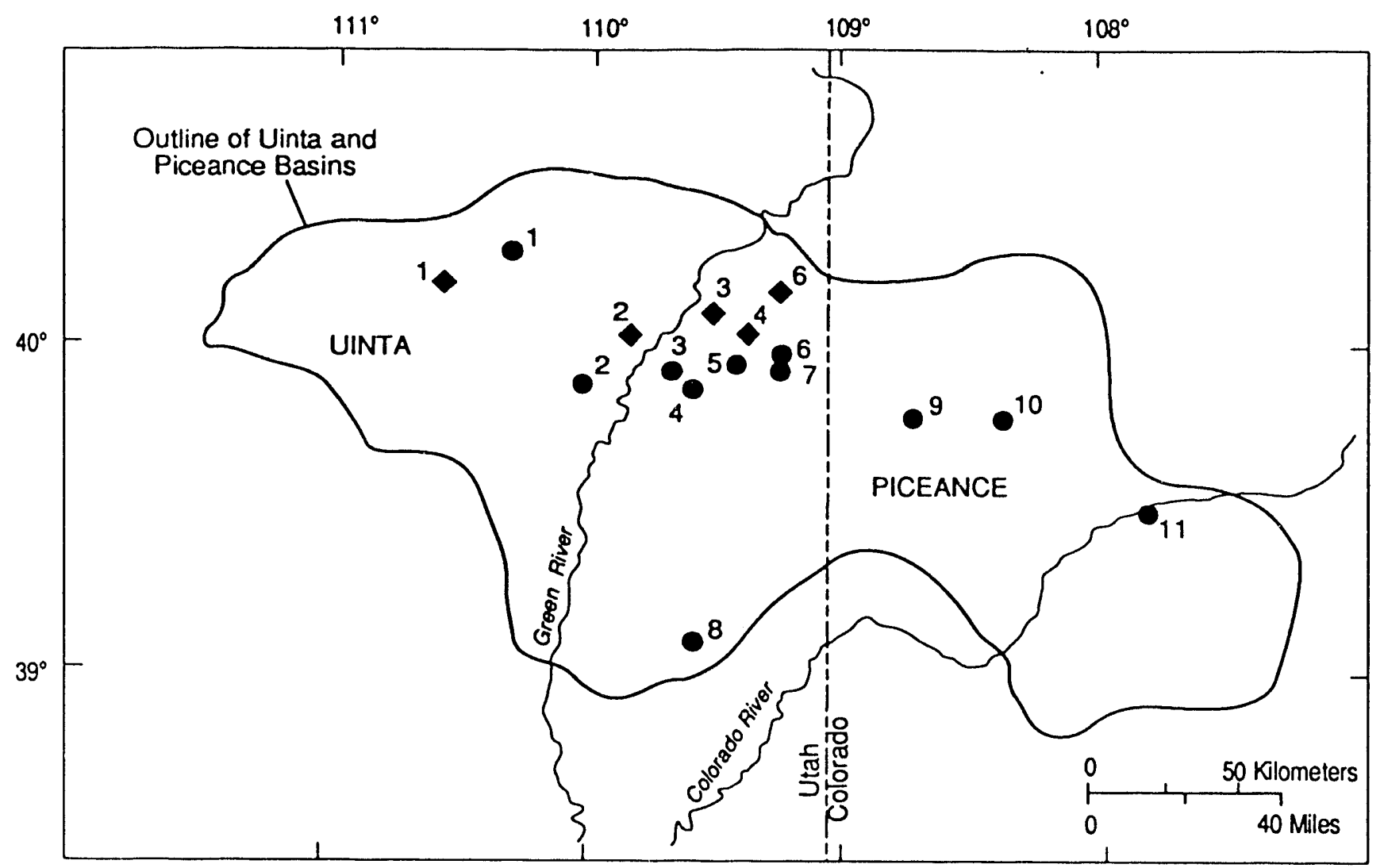

Figure 44. Map of Uinta and Piceance basins, Utah and Colorado, showing drill holes from which Upper Cretaceous Mesaverde Group (circles) and Tertiary Colton-Wasatch-Green River Formations (diamonds) core-plug porosity values were obtained for this report. Identification numbers refer to those of figure 44 and table 4.

than others simply because more core plugs were taken, cored intervals are represented by normalized porosity distributions. A porosity distribution cannot be easily graphed as such. Therefore, each distribution is characterized by the porosity of its 10 th, 25 th, 50th, $75 \mathrm{th}$, and $90 \mathrm{th}$ percentiles, as well as by its single highest porosity measurement. These values are easily plotted and are used to develop regional predictive trends of sandstone porosity versus vitrinite reflectance.

\section{Typical Porosities of Nonmarine Mesaverde Sandstones}

The vertical lines of figure 45 connect the 25 th and 75th porosity percentiles of each porosity distribution of the Mesaverde data set. These data characterize the middle one-half of the measured porosity range and define an envelope that subjectively represents normal or typical porosities of nonmarine Mesaverde sandstones.

Porosity- $\mathrm{R}_{\mathrm{m}}$ trend lines that represent sandstones in general are also shown in figure 45 . The line labeled "type curve" is from Schmoker and Gautier (1989) and is a typical compaction curve for clastic rocks. The lines labeled "10th percentile" and "90th percentile" (fig. 45) are from Schmoker and Hester (1990) and define an envelope within which most sandstone porosity- $R_{m}$ measurements fall. These three generic trend lines provide an interbasinal reference framework within which Mesaverde porosity data can be placed.

Porosities of Mesaverde sandstones in the Uinta and Piceance Creek basins have been subjectively described as low. Figure 45 demonstrates that this is not the case if the level of time-temperature exposure $\left(R_{m}\right)$ is taken into account. The dashed trend lines superimposed upon the data of figure 45 show that porosities of nonmarine Mesaverde sandstone intervals are, in an overall sense, typical of sandstones in general.

The unusual aspect of nonmarine Mesaverde sandstones is that their porosities remain approximately constant as $\mathrm{R}_{\mathrm{m}}$ increases from 0.7 percent to 1.8 percent (fig. 45). The porosities of most sandstones decrease as a power function of increasing $R_{m}$ over this range of thermal maturities (Schmoker and Hester, 1990).

The $\mathrm{R}_{\mathrm{m}}$ range for which porosities remain approximately constant (fig. 45) is within the window of active hydrocarbon generation for type III kerogen (Tissot 
Table 4. Description of Cretacoous Mesaverde Group core-plug porosity and vitrinite data sets used in this analysis. Wells are plotted by numbers in figure 44 .

\begin{tabular}{|c|c|c|c|c|c|c|}
\hline $\begin{array}{l}\text { ID } \\
\text { No. }\end{array}$ & Well Name & Location & Data Source & $\begin{array}{l}\text { No. of } \\
\text { Core-Plug } \\
\text { Porosity } \\
\text { Analyses }\end{array}$ & $\begin{array}{l}\text { Average } \\
\text { Core-Plug } \\
\text { Depth } \\
\text { (m) }\end{array}$ & $\begin{array}{l}\mathrm{R}_{\mathrm{m}}^{2} \\
\left(q_{0}\right)\end{array}$ \\
\hline 1 & Utex Brotherson 2-14B41 & $\begin{array}{l}\text { 4-T2S-R4W } \\
\text { Duchesne Co., Utah }\end{array}$ & Authors' data; Anders (1990) & 13 & 5,880 & 2.4 \\
\hline 2 & Exxon Wilkin Ridge 1 & $\begin{array}{l}\text { 29-T10S-R17E } \\
\text { Duchesne Co., Utah }\end{array}$ & Pitman et al. (1988) & $\begin{array}{l}15 \\
55\end{array}$ & $\begin{array}{l}3.140 \\
3.290\end{array}$ & $\begin{array}{l}0.74 \\
0.84\end{array}$ \\
\hline 3 & Mapco River Bend 11-17F & $\begin{array}{l}\text { 17-T10S-R20E } \\
\text { Uintah Co., Utah }\end{array}$ & Authors' data; Anders (1990) & 45 & 2,530 & 0.83 \\
\hline 4 & $\begin{array}{l}\text { Pacific Gas Transmission } \\
\text { Federal-Natural 1-7 }\end{array}$ & $\begin{array}{l}\text { 7.T11S-R21E } \\
\text { Uintah Co., Utah }\end{array}$ & Authors' data; Anders (1990) & $\begin{array}{l}24 \\
19\end{array}$ & $\begin{array}{l}2,130 \\
2,350\end{array}$ & $\begin{array}{l}0.79 \\
0.87\end{array}$ \\
\hline 5 & $\begin{array}{l}\text { Colorado Interstate Gas } \\
\text { Exploration Natural } \\
\text { Buttes } 21\end{array}$ & $\begin{array}{l}\text { 15-T10S-R22E } \\
\text { Uintah Co., Utah }\end{array}$ & $\begin{array}{l}\text { Authors' data; Pitman et al. } \\
(1986 ; 1987)\end{array}$ & $\begin{array}{c}8 \\
14 \\
14\end{array}$ & $\begin{array}{l}1.950 \\
2.290 \\
2,590\end{array}$ & $\begin{array}{l}0.75 \\
0.83 \\
0.95\end{array}$ \\
\hline 6 & Ensearch Petes Flat 1-1 & $\begin{array}{l}\text { 1-T10S-R23E } \\
\text { Uintah Co., Utah }\end{array}$ & Authors' data; Anders (1990) & 35 & 2.500 & 0.91 \\
\hline 7 & $\begin{array}{l}\text { Shell Southman Canyon } \\
\text { Unit } 7\end{array}$ & $\begin{array}{l}\text { 24-T10S-R23E } \\
\text { Uintah Co., Utah }\end{array}$ & $\begin{array}{l}\text { Keighin and Fouch (1981); } \\
\text { Anders (1990) }\end{array}$ & $?$ & 1.820 & 0.70 \\
\hline 8 & $\begin{array}{l}\text { Exxon Production Research } \\
\text { Sego Canyon } 2\end{array}$ & $\stackrel{?}{\text { Grand Co., Utah }}$ & $\begin{array}{l}\text { Authors' data; Wendlandt } \\
\text { and Bhuyan (1990) }\end{array}$ & $\begin{array}{l}33 \\
33\end{array}$ & $\begin{array}{l}200 \\
230\end{array}$ & $\begin{array}{l}0.56 \\
0.57\end{array}$ \\
\hline 9 & Twin Arrow C\&K 4-14 & $\begin{array}{l}\text { 14-T3S-R101W } \\
\text { Rio Blanco Co., Col. }\end{array}$ & $\begin{array}{l}\text { Authors' data; Johnson } \\
\text { and Nuccio (1986) }\end{array}$ & 50 & 340 & 0.50 \\
\hline 10 & $\begin{array}{l}\text { CER Geonuclear RBE-01 } \\
\text { CER Geonuclear RB-MHF-3 }\end{array}$ & $\begin{array}{l}\text { 14-T3S-R98W } \\
11-T 3 S-R 98 W \\
\text { Rio Blanco Co., Col. }\end{array}$ & $\begin{array}{l}\text { Authors' data; Hansley and } \\
\text { Johnson (1980); Johnson and } \\
\text { Nuccio (1986) }\end{array}$ & $\begin{array}{l}25 \\
29\end{array}$ & $\begin{array}{l}1,890 \\
1,830\end{array}$ & $\begin{array}{l}0.97 \\
0.93\end{array}$ \\
\hline 11 & $\begin{array}{l}\text { CER Geonuclear MWX- } \\
1,2 \text { and } 3\end{array}$ & $\begin{array}{l}\text { 34-T6S-R94W } \\
\text { Garfield Co., Col. }\end{array}$ & $\begin{array}{l}\text { Authors' data; Spencer and } \\
\text { Keighin (1984); Bostick and } \\
\text { Freeman (1984); Pitman et al. } \\
\text { (1989) }\end{array}$ & $\begin{array}{l}51 \\
26 \\
23 \\
28 \\
74 \\
93 \\
74 \\
54 \\
40\end{array}$ & $\begin{array}{l}1,310 \\
1,400 \\
1,430 \\
1,460 \\
1,490 \\
1,950 \\
1,980 \\
2,160 \\
2,230\end{array}$ & $\begin{array}{l}0.88 \\
0.93 \\
0.96 \\
1.00 \\
1.02 \\
\\
1.49 \\
1.73 \\
1.80\end{array}$ \\
\hline
\end{tabular}

1 Identification number refers to Figure 44.

$2 \mathrm{R}_{\mathrm{m}}=$ vitrinite reflectance.

and Welte, 1984). Hydrocarbons generated from interbedded coals and mudstones of the Mesaverde Group could possibly be directly or indirectly responsible for the observed Mesaverde porosity trends. Hydrocarbons, by displacing water, have the potential to inhibit burial diagenesis. Less directly, organic acids resulting from the thermal breakdown of kerogen can alter pore-water chemistry and affect subsurface reactions (Surdam and others, 1989).

Overpressuring produced by hydrocarbon generation in low-permeability rocks (Spencer, 1987) can also affect porosity evolution because of reduced lithostatic loading and a fluid-flow system characterized by expulsion rather than exchange of liquids. 


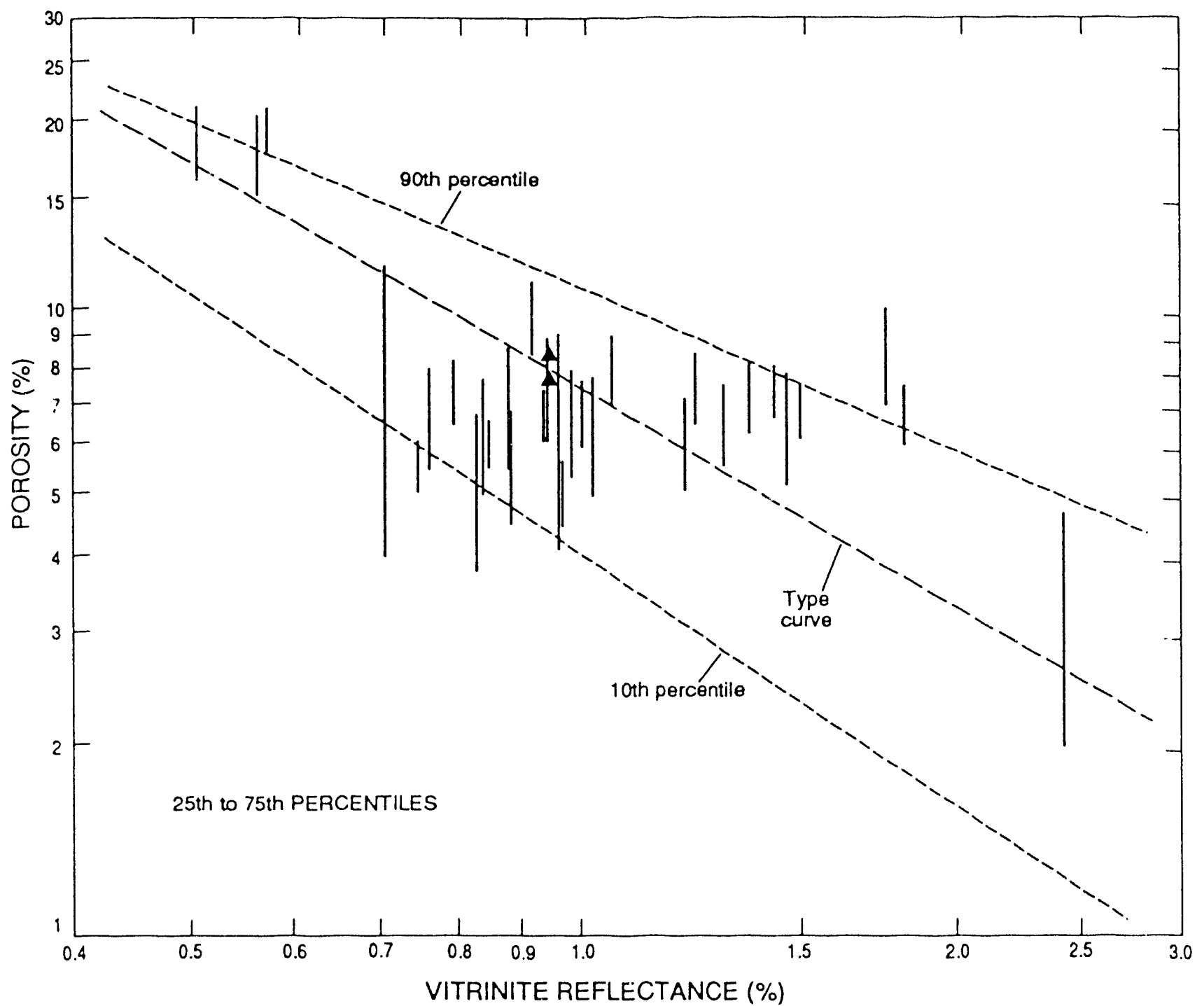

Figure 45. Plot of core-plug porosity versus :itrinite reflectance for 25 th and 75 th porosity percentiles (joined by verlical lines) of nonmarine sandstone intervals of Mesaverde Group, Uinta and Piceance Creek basins. Mesaverde data are compared to type curve and to 10th and 90th porosity percentiles representing sandstones in general (Schmoker and Gautier. 1989; Srhmoker and Hester. 1990). Arrows indicate values near the Cretaceous-Tertiary boundary.

Overpressured portions of the Mesaverde Group in the Uinta Basin cannot be accurately mapped at present. Well penetrations are sparse in many areas, few wells lest the base of overpressuring, and reliable pressure data are uncommon. However, limited data suggest that the Mesaverde section of the deep Uinta B asin may be regionally overpressured (Fouch, 1975; Spencer, 1987).

Hydrocarbons in pores, organic acids in pore waters, and regional overpressuring are all aspects of hydrocarbon generation within the Mesaverde Group. The possible effects of each upon the porosity of Mesaverde sandstones cannot be separated.

To summarize our interpretation of figure 45 , porosities of the three intervals with $\mathrm{R}_{\mathrm{m}}$ near 0.5 per- cent and of the single interval with $\mathrm{R}_{\mathrm{m}}$ of 2.4 percent are more or less typical of sandstones in general. The thermal maturities of these intervals are less than and greater than the window of active hydrocarbon generation, respectively. We speculate on the basis of these sparse data that porosities of nonmarine Mesaverde sandstones with thermal maturities less than or greater than the window of hydrocarton generation tend to follow the "normal" sandstone trends of Schmoker and Hester (1990). Within the window of hydrocarbon generation, we infer from figure 45 that porosities of nonmarine Mesaverde sandstones do not decrease with increasing thermal maturity. From the standpoint of hydrocarbon resources, this conclusion offers reas on for optimism. Deeply buried nonmarine Mesaverde 
sandstones can be expected to have average porosities in the 5 to 9 percent range, provided that $R_{m}$ does not exceed a threshold value somewhere near 2.0 percent.

\section{Influence Upon Porosity of Cretaceous- Tertiary Unconformity}

Hansley and Johnson (1980), studying thin sections from the RBE-01 well (no. 10 of fig. 44 and table 4), noted that secondary porosity in Mesaverde sandstones appears best devcloped immediately below the unconformity that separates Cretaceous and Tertiary strata in the Piceance Creek basin. They associated enhanced secondary porosity development with nearsurface weathering beneath the erosional surface. A similar concept was espoused by Shanmugam and Higgins (1988) with reference to the North Slope of Alaska. An unconformity might also enhance latestage secondary porosity development by focusing the flow of basin waters in the deep subsurface.

Of the porosity data collected for the present study, only those from the RBE-01 and RB-MHF-3 wells offer the possibility of testing whether Mesaverde sandstone porosity tends to be higher near the Cretaccous-Tertiary unconformity. Seven core-plug porosity measurements in the RBE-01 well are from nonmarine sandstones 35 to $85 \mathrm{ft}(11$ to $26 \mathrm{~m})$ below the unconformity and 29 core-plug porosity measurements in the RB-MHF-3 well are from nonmarine sandstones 10 to $180 \mathrm{ft}$ ( 3 to $55 \mathrm{~m}$ ) below the unconformity. (It is not clear how far below the unconformity a zone of enhanced dissolution might extend, although a thickness of a few hundred feet seems possible.)

The average porosities of these two data subsets are 8.6 and 7.9 percent, respectively. These average porosities are plotted in figure 45 (triangles) and are higher than the majority of Mesaverde porosity measurements in the vitrinite-reflectance range of 0.7 to 1.8 percent. On the basis of these data and the petrographic observations of Hansley and Johnson (1980), we speculate that the porosity of nonmarine Mesaverde sandstones in close proximity to the Cretaceous-Teriary unconformity is enhanced, all else being equal, because of better secondary porosity development.

\section{Above Average Porosities of Nonmarine Mesaverde Sandstones}

A well may require only a single interval of atypical (high) porosity and permeability to be successful. For this reason, a plot depicting trends of unusually high sandstone porosities is of particular importance. The vertical lines of figure 46 connect the 75th porosity percentile and single highest core-plug porosity measurement of each porosity distribution of the Mesaverde data set. These data characterize the upper quartile of the measured porosity range and define an envelope that subjectively represents the better (higher) porosities of nonmarine Mesaverde sandstones.

The upper-quartile porosity range is rel tively narrow (fig. 46). The single highest porosity measurements are not distant outliers. The general trends of upper-quartile porosities versus $\mathrm{R}_{\mathrm{m}}$ (fig. 46) parallel those of figure 45 and presumably reflect the same causative factors.

Two somewhat arbitrary lines are superimposed on the data of figure 46 . One merely marks the 8 percent porosity level, which is sometimes taken as a generic lower porosity limit for conventional sandstone reservoirs. The other, based on the rather sparse available data, approximates the high-porosity limit for nonmarine Mesaverde sandstones. For $R_{m}$ between 0.7 and 1.8 percent, some porosities greater than 8 percent are likely; the maximum porosity that can rationally be hoped for is about 13 percent (fig. 46).

\section{Comparison of Porosities-Mesaverde Group and Wasatch-Green River Formations}

Tertiary rocks of the Uinta Basin are separated from Cretaceous strata by a regional unconformity. In contrast to the underlying Mesaverde Group, the Wasatch and Green River Formations have undergone only a single, relatively simple cycle of burial, uplift, and erosion (Narr and Currie, 1982). The question posed here is whether the Mesaverde porosity $-\mathrm{R}_{\mathrm{m}}$ trends of figure 45 can be projected across the Cretaceous-Tertiary unconformity and used as a predictive porosity model for sandstones of the Wasatch and Green River Formations.

This question is addressed using 550 core-plug porosity measurements from undifferentiated sandstones of the Wasatch and Green River Formations. These data span a vitrinite-reflectance range of 0.45 to 0.68 percent and are from seven wells in the Uinta Basin. The solid vertical lines of figure 47 connect the 25th and 75th porosity percentiles of each porosity distribution of the Wasatch-Green River data set. To facilitate the comparison of Wasatch-Green River and Mesaverde porosity data, a portion of figure 45 (representing Mesaverde data) is reproduced in figure 47.

Porosities of Wasatch and Green River sandstones (solid vertical lines) are substantially lower than those of Mesaverde sandstones (dashed vertical lines) at the same $\mathrm{R}_{\mathrm{m}}$ (fig. 47). Within the thermal-maturity range 


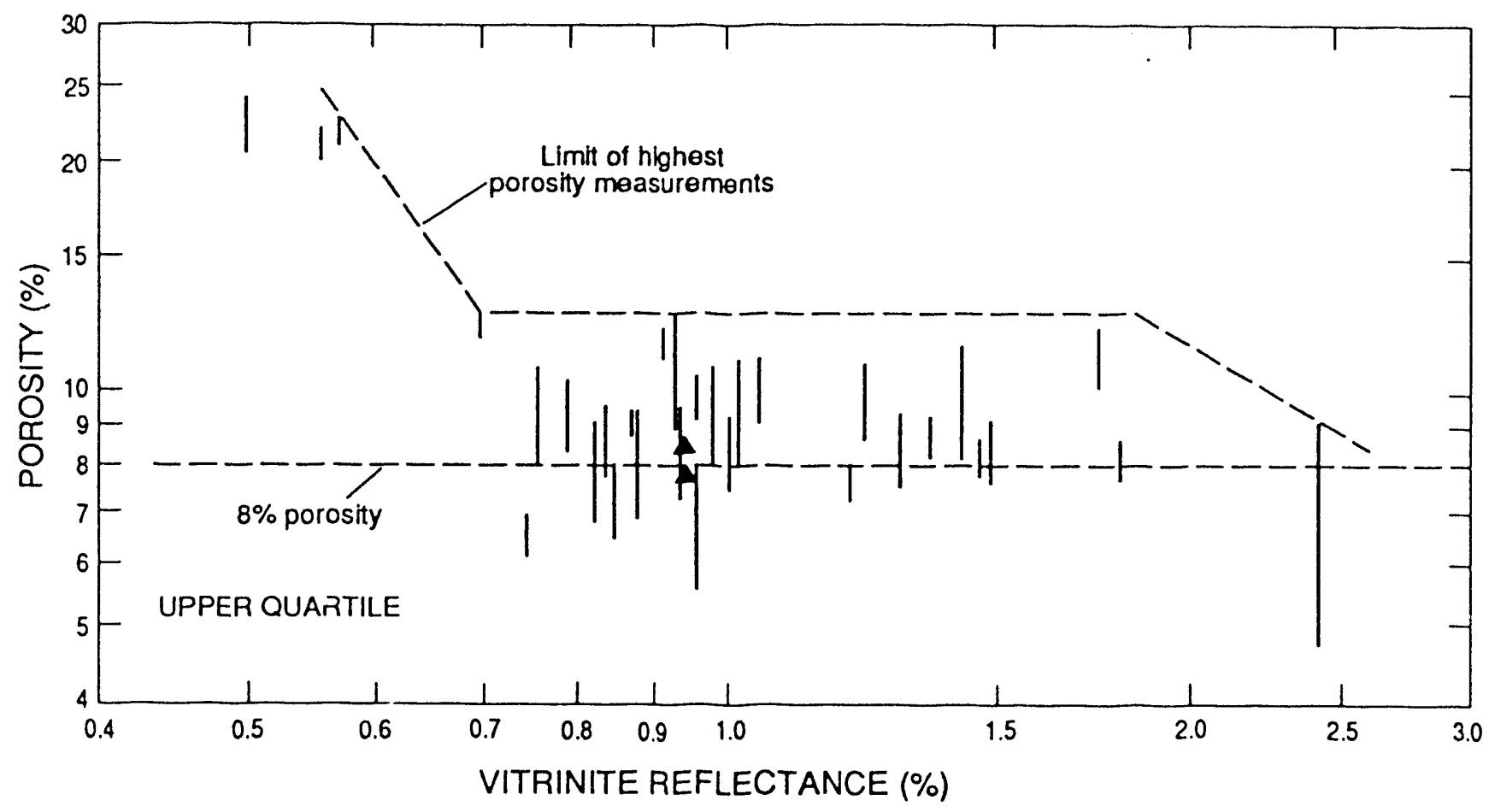

Figure 46. Porosity versus vitrinite reflectance for upper quartile of core-plug porosity values, nonmarine sandstone intervals of Mesaverde Group, Uinta and Piceance Creek basins. Vertical lines connect 75th porosity percentiles and single highest porosity measurements in Magoon, L.B., The Petroleum System-Status of Research and Methods 1991. Data set is described in table 4.

for which a comparison can be made, the porosity- $R_{m}$ trend of Wasatch and Green River sandstones is parallel to but below that of Mesaverde sandstones. The porosities of Wasatch and Green River sandstones are also low relative to the generic trend lines representing sandstones in general (fig. 47). Figure 47 shows that the predictive porosity model developed for nonmarine sandstones of the Mesaverde Group cannot be extrapolated across the Cretaceous-Teniary unconformity and applied to sandstones of the Wasatch and Green River Formations.

\section{Predicting Porosity for the Mesaverde Group Using Maturity-Porosity Trends}

Predictive porosity trends can be developed for the deeper, unexplored parts of the basin when porosity is represented as a function of thermal maturity. Porosities of nonmarine Mesaverde sandstones with thermal maturities less than or greater than the window of hydrocarbon generation follow normal sandstones trends. Within the window of hydrocarbon generation (for this study we use 0.70 to 1.8 percent $R_{m}$ ) we infer nonmarine Mesaverde sandstones do not decrease as maturity increases (fig. 45). Deeply buried sandstones of the nonmarine Mesaverde should have porosities in the 5 to 9 percent range when thermal maturities do not exceed values of around 1.8 to 2.0 percent. Based on figure 45 and maps presented in figures 28 and 29, the porosity prediction map of the base of the Mesaverde Group (fig. 48), was constructed to show the zone (shaded area) where nonmarine Mesaverde sandstone porosities do not decrease as thermal maturity increases ( 0.70 to 1.8 percent $R_{m}$ ). Generally speaking, this defines the area of optimum gas recovery for the lower part of the Mesaverde Group.

Figure 49 is the porosity prediction map on the top of the Mesaverde Group showing the area ( 0.70 to 1.80 percent $R_{m}$ ) where sandstone porosities do not decrease with increasing maturity. This map can be used to define the area of optimum gas recovery for sandstones near the top of the Mesaverde Group.

\section{SUMMARY}

Most known accumulations of gas are found within rocks of the Upper Cretaceous Mesaverde Group, uppermost Cretaceous to early Eocene North Horn Formation, and the Paleocene and Eocene Wasatch, Colton, and Green River Formations. Much of the gas 


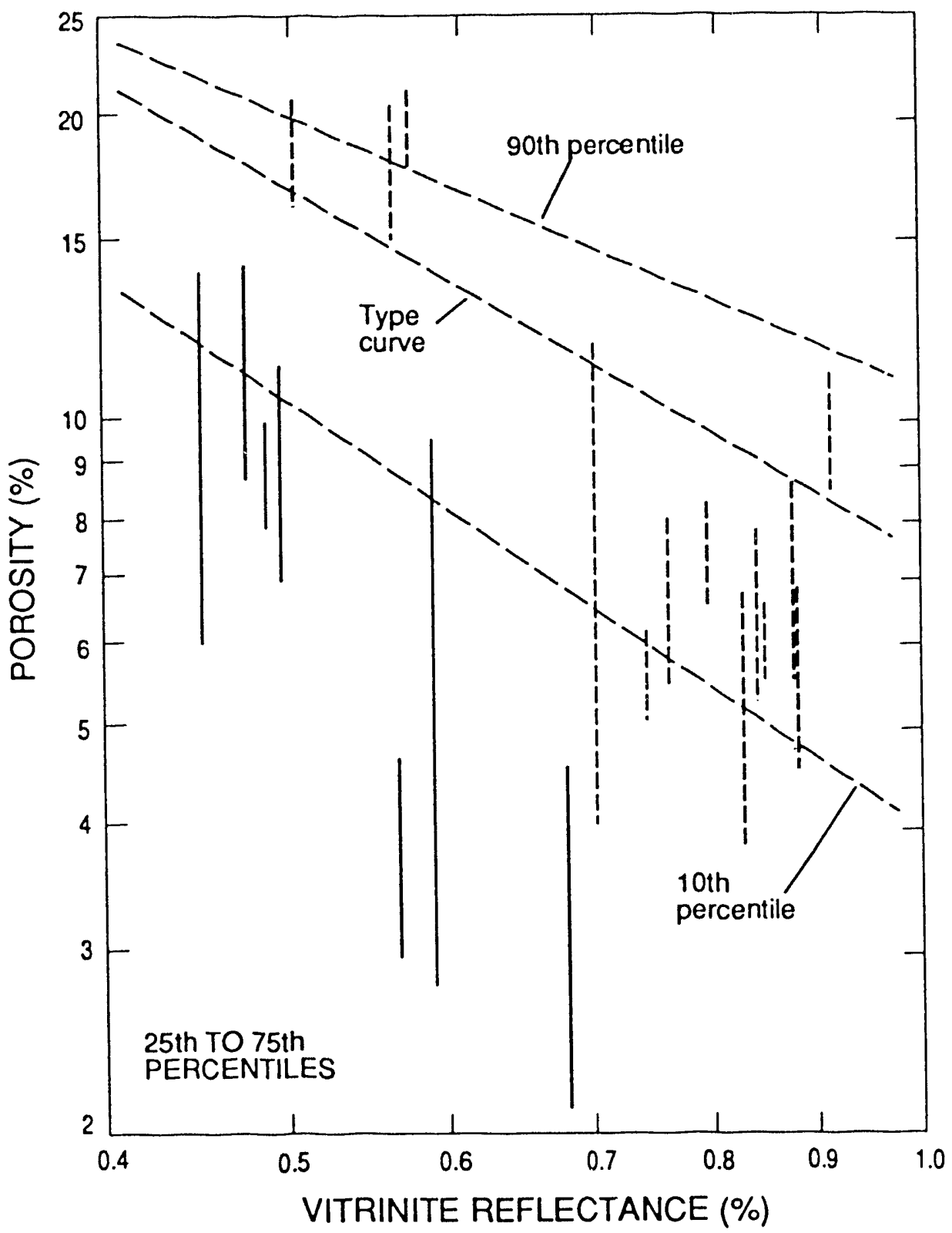

Figure 47. Porosity versus vitrinite reflectance for sandstone intervals of Wasatch and Green River Formations compared 10 equivalent data for Mesaverde Group. Solid vertical lines connect 25th and 75th core-plug-porosity percentiles of Wasatch-Green River data, Uinta basin. Dashed vertical lines represent Mesaverde Group. See caption of figure 46 for additional explanation and table 4 for description of data set. Within thermal-maturity range for which data are available. porosities of Wasatch and Green River Formations at a given vitrinite reflectance are lower than those of Mesaverde Group.

production is from fields developed along the trace of faults and fractures in the eastern part of the basin.

The productive oil and gas-bearing rocks can be divided into three groups of common reservoir character. Group I is composed of oil- and associated gasbearing deeply buried overpressured Tertiary strata that are characterized by reservoirs whose in situ matrix permeability values are near, and are commonly below, $0.1 \mathrm{md}$ and whose porosity values (most porosity being secondary) average 5 percent, ranging from 3 to 10 percent. These strata contain open fractures and transmissivity $(T=$ permeability $\mathrm{x}$ height $)$ values through producing intervals that are commonly high. Group Il rocks are characterized by combined primary and secondary porosity values of 10 to 16 percent in normally pressured Tertiary oil and associated gas reservoirs whose matrix permeability values may be as high as $1 \mathrm{~d}$. Transmissivity values for such sequences can be relatively high because of their high matrix permeability. Group III rocks include nonassociated gas Tertiary and Cretaceous sandstone reservoirs that commonly contain porosity values ranging from 8 to 


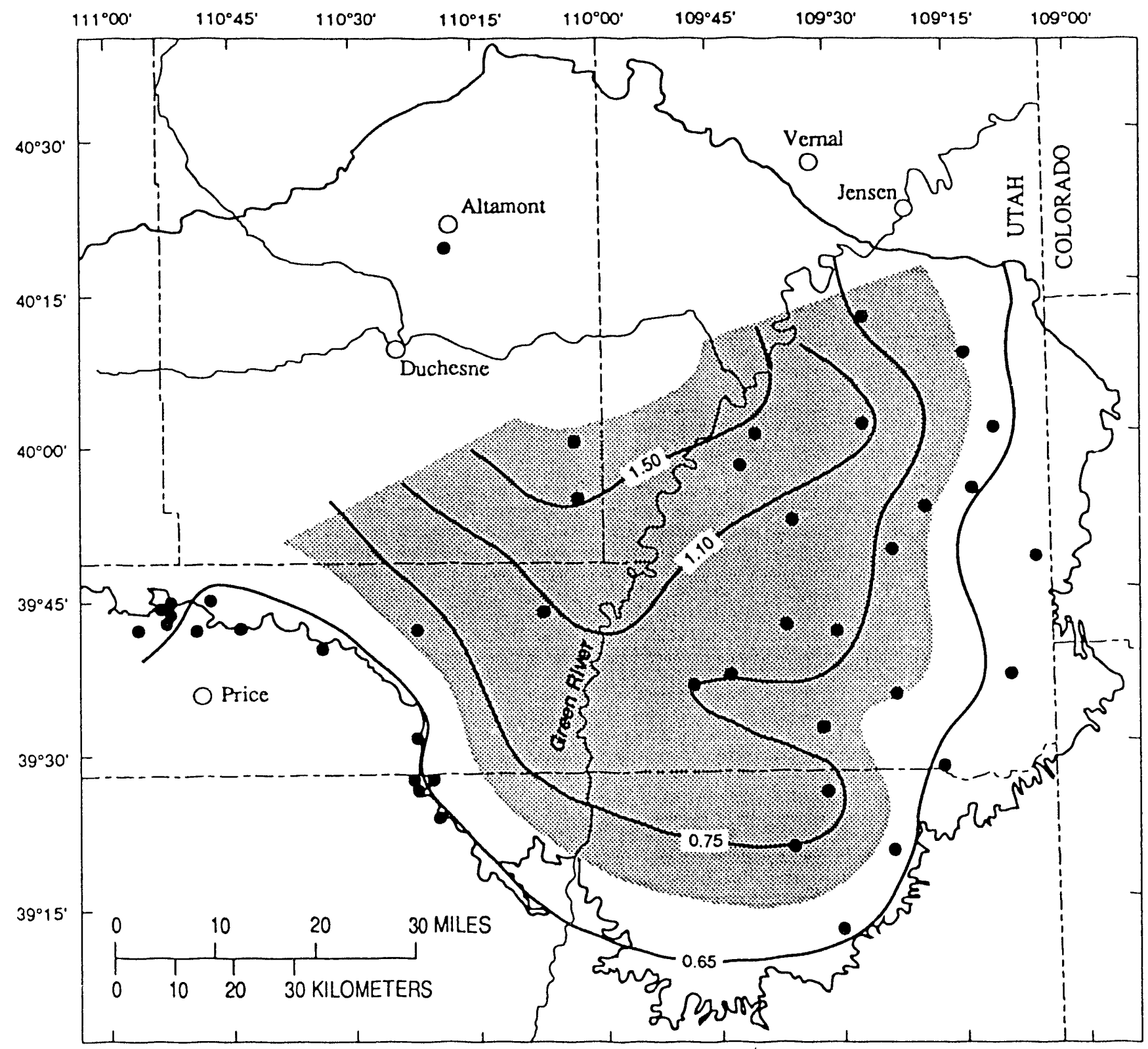

Figure 48. Map of the Uinta Basin, Utah showing the region (shaded area) between $R_{m} 0.70$ percent and 1.8 percent where porosity of sandstones at the base of the Mesaverde Group does not decrease as a function of increasing $R_{m}$. This is the area of optimum recovery for gas-bearing sandstones near the lower part of the Mesaverde Group.

16 percent, but whose in situ permeability throughout the pay or gas producing section is $0.1 \mathrm{md}$ or less to gas (exclusive of fracture permeability) are classified as tight gas sandstones. Transmissivity values for productive "tight gas" intervals are very low because of relatively few natural open fractures.

Structural discontinuities that cut the Cretaceous and Teriary units of the basin represent reactivation of covered structures associated with the ancestral Uncomphagre. We believe that much of that gas has migrated from Cretaceous source rock: through a permeable network of faults and fractures in Cretaceous and Tertiary strata to the slightly overpressurred to normally pressured reservoirs of the Mesaverde Group and Wasatch Formation in the eastem and southern parts of the basin. Natural fractures provide major conduits to move fluids and gases to the wellbore in otherwise very low-permeability strata. An evident lack of significant natural open fracture systems in impermeable strata of the southeastem part of the Uinta Basin (area of tight-gas production) has resulted in very low producibility.

Projection of maturity values and fluid-pressure data to undrilled parts of the basin indicate the probability of regional, overpressurred, basin-centered gas accumulation, where gas generation is likely to be 


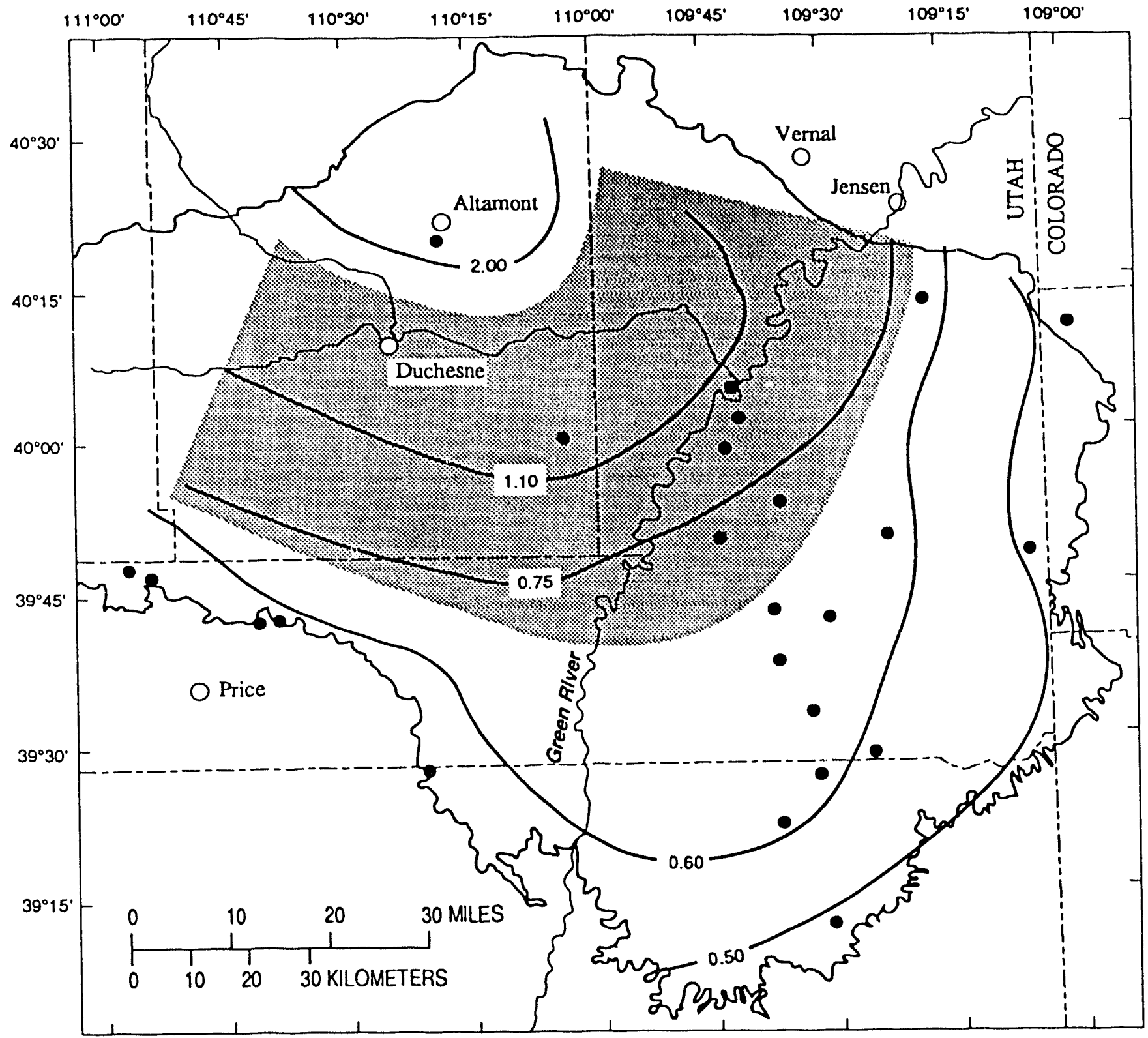

Figure 49. Map of the Uinta Basin, Utah showing the region (shaded area) between $R_{m} 0.70$ percent and 1.8 percent where porosity of sandstones at the top of the Mesaverde Group does not decrease as a function of increasing $R_{m}$. This is the area of optimum recovery for gas-bearing sandstones near the top of the Mesaverde Group.

occurring at present. Published estimates of amounts of erosion vary widely, ranging from $1,000 \mathrm{ft}$ to almost $11,000 \mathrm{ft}$. Our interpretation favors the lesserestimates because significant cooling of strata due to uplift and erosion would slow or stop the generation of hydrocarbons.

Based on chemical and isotopic composition, two classes (types) of thermogenic gases have been identified in the Uinta Basin. Class $A$ is nonassociated, chemically dry, and isotopically heavy. This gas is interpreted to have been generated from type III kerogen in the Mesaverde Group at high levels of themal maturity (late catagenesis and metagenesis). This gas occurs in both Mesaverde and Wasatch reservoirs over a wide depth range in the greater Natural Buttes and Red Wash field areas.

Class B gas is chemically wet and isotopically light, and is associated with oil. Class B gas was generated during time of major oil generation (catagenesis) and from type I kerogen typical of Green River lacustrine facies. Thermogenic hydrocarbons were generated in the deep part of the basin to the north (Altamont-Bluebell field area). The presence of this type of gas in shaliow, immature reservoirs in the Red Wash field indicates extensive lateral migration from the Altamont-Bluebell field area. This interpreted di- 
rection of gas migration (castward) is the same as that for fluid flow as interpreted from pressure data.

In general, potential reservoir rocks throughout the basin have low porosity and matrix permeability except Red Wasti field which is typified by higher porosity and permeability because of its shallow-burial depths. The Altamont-Bluebell field also is somewhat atypical because it is extensively fractured and has produced large amounts of liquid hydrocarbons via a well-developed interconnected fracture system that pervades otherwise tight rocks. Analysis of reservoir quality in these strata is important because they are the most deeply-buried rocks in the region thus, their reservoir characteristics should be in sharp contrast to those in less deeply-buried strata.

Low-permeability sandstones in the Uinta Basin display a wide range in composition. The data generally cluster into three distinct groups: a quartz-lithic petrofacies, a quarzose petrofacies, and a feldspathiclithic petrofacies. Each of these facies spans a broad stratigraphic interval ranging from Late Cretaceous through early Tertiary in age. The quartz-lithic petrofacies, composed predominantly of monocrystalline quartz and sedimentary lithic fragments, comprises litharenites and sublitharenites in the Upper Cretaceous Blackhawk Formation which extends from the western through the central part of the basin, the Upper Cretaceous Neslen Formation deposited east of the Green River, and the parts of the lower Tertiary Wasatch and Green River Formations that are geographically restricted to the northem and eastern parts of the basin. Quanzarenites of the quartzose petrofacies typify the Upper Cretaceous Bluecastle Tongue of the Castlegate Sandstone and they form distinct beds that are intercalated with quartz-lithic-rich strata of the Wasatch and Green River Formations in the northern and eastern areas of the basin. The feldspathic-lithic petrofacies, classifying mostly as lithic arkoses and feldspathic litharenites, characterizes sandstones in the Upper Cretaceous undifferentiated Farrer-Tuscher Formation deposited in the area east of the Green River, the temporally-equivalent Price River Formation restricted to the area west of the Green River, and the lower Tertiary Wasatch, Colton, and Green River Formations that extend throughout much of the central and southem parts of the basin.

The reservoir quality of Upper Cretaceous and Tertiary rocks at Natural Buttes and nearby areas is influenced by stratigraphic position within a depositional sequence, petrofacies type, and the nature and extent of burial alteration. Consistently low permeability reflects the abundant matrix and pseudomatrix that characterizes these rocks. Dissimilar reservoir quality between individual beds within each formation can be attributed to differences in grain size and soring and to the relative abundance of individual grain types.

Permeability in these Upper Cretaccous and Tertiary rocks was most affected by the development of authigenic clay in residual pores. Clay-filled pores exhibit microporosity which tends to be discontinuous thus inhibiting the movement of fluids or hydrocarbons through the pore network.

Plots of porosities versus Rm for Mesaverde sandstones in the Uinta and Piceance basins, between 0.70 and 2.0 percent, in the window of hydrocarbon generation, show that porosity values do not decrease as thermal maturity increases. Overpressurred, gas-saturated Mesaverde sandstones are likely to have porosities in the 5 to 9 percent range.

A large area of organic-rich overpressured Upper Cretaceous strata probably underlies the north-central part of the Uinta Basin. Wells drilled in the areas where $\mathrm{R}_{\mathrm{m}}$ at the base of the Mesaverde is greater 1.1 percent should have the best potential for gas production. Overpressurred gas reservoirs $\left(R_{m}>1.1\right.$ percent) are likely to have no free water and be enveloped by successive zones of mixed water and gas $\left(R_{m} 1.1\right.$ to 0.75 percent), and of water only (Rm, 0.75 percent)

\section{ACKNOWLEDGEMENTS}

U.S. Geological Survey studies of oil- and gasbearing Upper Cretaceous and lower Tertiary strata in the basin are designed to characterize the reservoir units, and to assess the basin's gas resources in tight siliciclastic reservoirs. The U.S. Department of Energy's Westem Tight Gas Sands Program is a major funder of this endeavor as is the U.S. Geological Survey's Onshore Oil and Gas, and Evolution of Sedimentary Basins Programs.

\section{REFERENCES CITED}

Abboth, W.O., and P.J. Katich, 1956, Stratigraphy of the Eook Cliffs in East-Central Utah: Peterson, J.A., ed., Intermountain Association of Petroleum Geologists seventh Annual Field Conference: Geology and Economic Deposits of East Central Utah.

Anders, D.E., 1990, Thermal maturation in the Uinta basin, Utah (abs.), in Carter, L.M.H., ed., USGS Research on Energy Resources-1990 program and abstracts, Sixth V.E. McKelvey Forum on Mineral and Energy Resources: U.S. Geological Survey Circular 1060, p. 2-3. 
Anders, D.E., and Gerrild, P.M., 1984, Hydrocarbon generation in lacustrine rocks of Tertiary age, Uinta Basin, Utah-organic carbon, pyrolysis yicld, and light hydrocarbons, in Jane Woodward, Meissner, F.F., and Clayton, J.L., eds., Hydrocarbon source rocks of the Greater Rocky Mountain Region: Denver, Rocky Mountain Association of Geologists, p. 513-529.

Boardman, C.R., and C.F. Knutson, 1980, Reservoir characteristics in Uinta basin gas wells: U.S. Department of Energy Repon DOE/ET/11399-1, 89 p., 26 tables, 36 figures.

Boardman, C.R., and C.F. Knutson, 1981, Uinta basin lenticular sandstone reservoir characteristics: SPE/ DOE Paper 9849, SPE/DOE Low Permeability Symposium, p. 217-222.

Bostick, N.H., and Freeman, V.L., 1984, Tests of vitrinite reflectance and paleotemperature models at the Multiwell Experiment Site, Piceance Creek basin, Colorado, in Spencer, C.W., and Keighin, C.W., eds., Geologic studies in support of the U.S. Department of Energy Multiwell Experiment, Garfield County, Colorado: U.S. Geological Survey Open-File Report 84-757, p. 110-120.

Bryant, Bruce, Naeser, C.W., Marvin, R.F., and Mehnert, H.H., 1989, Upper Cretaceous and Paleogene sedimentary rocks and isotopic ages of Paleogene tuffs, Uinta Basin, Utah: U.S. Geological Survey Bulletin 1787-J, 22 p.

Bryant, Bruce, 1991, Geologic map of the Salt Lake City $1 \times 2$ quadrangle, Utah and Wyoming: U.S. Geological Survey Miscellaneous Investigations Series Map I-1997, 2 sheets.

Bumham, A.K., Braun, R.L.,Gregg, H.R., and Samoun, A.M., 1987, Comparison of methods for measuring kerogen pyrolysis rates and fitting kinetic parameters: Energy and Fuels, v .4, p. 132-146.

Campbell, J.A., 1975, Structural geology and petroleum potential of the south flank of the Uinta Mountain uplift, northeastem Utah, Utah Geology, v. 2, no. 2, p. 129-132, 2 figs, 2 plates, 1 table.

Cashion, W. B., and Donnell, J.R., 1972, Chart showing correlation of selected key units in the organic-rich sequence of the Green River Formation, Piceance Creck basin, Colorado, and Uinta Basin, Utah: U.S. Geological Survey Cil and Gas Investigations Chart OC-65.

Cashion, W. B., and Donnell, J.R., 1974, Revision of nomenclature of the upper part of the Green River Formation, Piceance Creek basin, Colorado, and eastem Uinta basin, Utah: U.S. Geological Survey Bulletin 1394-G, 9 p.
Cashion, W.B., 1972, Gcology and fuel resources of the Green River Formation, southeastem Uinta Basin, Utah and Colorado: U.S. Geological Survey Professional Paper 548, $48 \mathrm{p}$.

Cashion, W.B., 1973, Geologic and structure map of the Grand Junction quadrangle, Colorado and Utah: U.S. Geological Survey Miscellaneous Geologic Investigations Map I-736.

Casue, J.W., 1990, Sedimentation in Eocene Lake Uinta (LowerGreen River Formation), northeastem Uinta Basin, Utah, in Katz, B.J., ed., Lacustrine Basin Exploration-Case Studies and Modern Analogs: American Association of Petroleum Geologists Memoir 50, p. 243-264.

Chatfield, J., 1972, Case history of Red Wash ficld, Uintah County, Utah: in King, R.E., ed., Stratigraphic Oil and Gas Fields-Classification, Exploration Methods, and Case Histories: American Association of Petroleum Geologists Memoir 16, p. 343-353.

Clem, Keith, 1985, Oil and gas production summary of the Uintabasin: Picard, M.D., ed., Utah Geological Association Publication 12: Geology and Energy Resources, Uinta Basin of Utah, p. 159-168.

Colbum, J.A., S.R. Bereskin, D.C. McGinley, and D.M. Schiller, 1985, Lower Green River Formation in the Pleasant Valley Producing area, Duchesne and Uintah Counties, Utah, in Picard, M.D., ed., Utah Geological Association Publication 12: Geology and Energy Resources, Uinta Basin of Utah, p. 177-186.

Dane, C.H., 1955, Stratigraphic and facies relationships of the upper part of the Green River Formation and the lower part of the Uinta Formation in Duchesne, Uintah, and Wasatch Counties, Utah: U.S. Geological Survey Oil and Gas Investigations Chart OC-52, 2 sheets.

Dow, W.G., 1977, Kerogen studies and geological interpretations: Journal of Geochemical Exploration, v. 7, p. 79-99.

Dyni, John R., and J.E. Hawkins, 1981, Lacustrine turbidites in the Green River Formation, northwestern Colorado: Geology, v. 9, p. 235238.

Fisher, D.J., Erdman, C.E., and Reeside, J.B., Jr., 1960, Cretaceous and Tertiary formations of the Book Cliffs, Carbon, Emery, and Grand Counties, Utah and Garfield and Mesa Counties, Colorado: U.S. Geological Survey Professional Paper 332, p. 80.

Folk, R.L., 1974, Petrology of Sedimentary Rocks: Austin, Hemphill's Publishing Co., 182 p. 
Fouch, T. D., 1976, Revision of the lower part of the Tertiary System in the central and western Uinta Basin, Utah: U.S. Gecingical Survey Bulletin 1405-C. p. C1-C7.

Fouch, T. D., 1985, Oil- and Gas-bearing Upper Cretaceous and Paleogene fluvial rocks in central and northeast Utah: Recognition of Fluvial Depositional Systems an 1 Their Resource Potential, Chapter 10, p. 241-272.

Fouch, T. D., and Cashion, W. B., 1979, Distribution of rock types, lithologic groups, and depositional environments for some lower Tertiary and Upper and Lower Cretaceous, and Upper and Middle Jurassic rocks in the subsurface between Altamont oil ficld and San Arroyo gas field, north-central to southeastem Uinta Basin, Utah: U.S. Geological Survey Open-File Report 79-365, 2 sheets.

Fouch, T. D., J. K. Pitman, J. B. Wesley, A. Szantay, and F. Ethridge, 1990, Sedimentology, diagenesis, and reservoir character of Paleogene fluvial and lacustrine rocks, Uinta intermontane basin, Utah: evidence from the Altamont and Red Wash fields; [abs.], 1990 McKelvey Forum: U.S. Geological Survey Circular 1060: p. 31-32.

Fouch, T.D., 1975, Lithofacies and related hydrocarbon accumulations in Tertiary strata of the westem and centu al Uinta basin, Utah: in Bolyard, D.W. (ed.), Rocky Mountain Association of Petroleum Geologists Symposium on Deep Drilling Frontiers of the Central Rocky Mountains, p. 163-174.

Fouch, T.D., Lawton, T.F., Nichols, D.J., Cashion, W.B., and Cobban, W.A., 1983, Patterns and timing of synorogenic sedimentation in Upper Cretaceous rocks of central and northeast Utah, in Reynolds, M.W. and Dolly, E.D., eds., Mesozoic Palcogeography of the West-Central United States: Rocky Mountain Paleogeography Symposium, p. 305-336.

Fouch, T.D., Wandrey, C.J., Pitman, J.K., Nuccio, V.F., Schmoker, J.W., Rice, D.D., and Wesley, J.B., 1991, Preliminary report on the characterization of Tertiary and Cretaceous lowpermeability (tight) gas-bearing rocks in the Uinta Basin, Utah, in Malone, R.D., Shocmaker, H.D., and Bryer, C.W., eds., Proceedings of the 1990 Natural Gas Research and Development Conference: U.S. Department of Energy, U.S. Department of Energy report DOE/METC-91/ 6117, p. 5-14.

Fouch, Thomas D., 1981, Distribution of rock types, lithologic groups, and interpreted depositional environments for some lower Tertiary and Upper Cretaccous rocks from outcrops at Willow CreckIndian Canyon through the subsurface of Duchesne and Altamont oil fileds, southwest to north-central parts of the Uinta Basin, Utah: United States Gcological Survey (Oil and Gas Investigations Map Chart OC-81, 2 sheets.

Fouch, T.D., and J.K. Pitman, 1991, Tectonic and climate changes expressed as sedimentary cycles and stratigraphic sequences in the Palcogene Lake Uinta system, central Rocky Mountains, Utah and Colorado, [abs.]: American Association of Petroleum Gcologists Bulletin, v. 75, no. 3, p. 575.

Fouch, T.D., and Pitman, J.K., in press, Tectonic and climate changes expressed as sedimentary and geochemical cycles-Palcogene Lake systems, Utah and Colorado-implications for petrolcum source and reservoir rocks, in Carter, L.M.H., cd., [abs.]: USGS Research on Energy resources1992, Program and Abstracts, U.S. Gcological Survey Circular.

Franczyk, K. J.,Fouch, T. D.,Johnson, R. C., and Molenaar, C. M., in press, Cretaceous and Tertiary paleogeographic reconstructions for the UintaPiceance study area: U.S. Gcological Survey Bulletin 1787-Q, $48 \mathrm{MS}$ pages, 25 figs., 1 table.

Franczyk, K.J., Pitman, J.K., Cashion, W.B., Dyni, J.R., Fouch, T.D., Johnson, R.C., Chan, M.A., Donnell, J.R., Lawton, T.F., and Remy, R.R., 1989. Evolution of resource-rich foreland and intermontane basins in eastem Utah and westem Colorado: 28th International Geologic Congress Field Trip Guidebook T-324, p. 53 p.

Gillespie, W.A., 1957, Ute Trail field - Uintah County, Utah: Intermountain Association of Petroleum Geologists Eigth annual Field Conference Guidebook to the Gcology of the Uinta Basin. p. 202-203.

Gries, Robbie, 1983, Oil and gas prospecting beneath Precambrian of foreland thrust plates in the Rocky Mountains: American Association of Petrolcum Geologists Bulletin, v. 67, p. 1-28.

Hansley, P.L., and Johnson, R.C., 1980, Mineralogy and diagenesis of low-permeability sandstones of Late Cretaceous age, Piceance Creek basin, northwestem Colorado: The Mountain Geologist, v. 17, no. 4, p. 88-106.

Hendel, C.W., 1957, The Peters Point gas field: Intermountain Association of Petroleum Geologists Eigth annual Field Conference Guidebook to the Geology of the Uinta Basin, p. 193-201. 
Hintze, L. F., 1980, Geologic Map of Utah: Utah Geological and Mineral Survey, 2 sheets, $1: 5(0),(0)(0)$.

Hodges, L.T., and Knutson, C.F., 1981, Tight gas sandstone channel continuity and directivity, Upper Cretaceous Lance and Paleocene, Greater Green River Basin, Wyoming, in Procecdings of the 1981 SPE/DOE Sympnsium on Low Permeability Gas Reservoirs: Socicty of Petrolcum Engineers and U.S. Department of Energy, SPE/DOE paper 9844 , p. $165-176$.

Horner, D. R., Pressure Build-up in Wells: Proceedings of the Third World Petroleum Conference, 1951.

James, A.T., 1983, Correlation of natural gas by use of carbon isotopic distribution between hydrocarbon components: American Association of Petroleum Gcologists Bulletin, v. 67, p. 1176-1191.

James, A.T., 1990, Correlation of reservoired gases using the carbon isotopic composition of wet gas components: American Association of Petroleum Gcologists Bulletin, v. 74, p. 1441-1458.

Jennings, J.B., Carroll, H.B., and Raible, C.J., 1981, The relationship of permeability to confining pressure in low permeability rock, in Procecdings of the 1981 SPE/DOE Symposium on Low Permeability Gas Reservoirs: Society of Petroleum Engineers and U.S. Department of Energy, SPE/ DOE paper 9870, p. 391-398.

Johnson R.C., and Rice, D.D., 1990, Occurrence and Geochemistry of natural gases, Piceance basin, northwest Colorado: American Association of Petroleum Geologists Bulletin, v. 74, p. 805-829.

Johnson, R.C., 1985, Early Cenozoic history of the Uinta and Piceance Creek basins, Utah and Colorado, with special reference to the development of Eocene Lake Uinta, in Flores, R. M., and Kaplan, S.S., eds.: Cenozoic Paleogeography of the Westcentral United States, p. 247-276.

Johnson, R.C., 1989, Geologic history and hydrocarbon potential of Late Cretaccous-age, low permeability reservoirs, Piceance basin, westem Colorado: U.S. Geological Survey Bulletin 1787-E, p. E1-E51.

Johnson, R.C., and Nuccio, V.F., 1986, Structural and thermal history of the Piceance Creek basin, western Colorado, in relation to hydrocarbon occurrence in the Mesaverde Group, in Spencer, C.W., and Mast, R.F., eds., Geology of tight gas reservoirs: American Association of Petroleum Geologists Studies in Geology No. 24, p. 165-205.

Johnson, R.C., and Nuccio, V.F., in press, A surface vitrinite reflectance study of the Uinta-Piceance basin area, westem Colorado and eastem Utah and its implications for the development of Laramide basins and uplifts: U.S. Gcological Survey Bulletin, 48 p., 24 figures, 1 plate.

Johnson, R.C., Crovelli, R.A., Spencer, C.W., and Mast, R.F., 1987, An assessment of gas resources in low-permeablilty sandstones of the Upper Cretaceous Mesaverde Group, Piceance basin, Colorado: U.S. Geological Survey Open-File Report 87-357, 165 p.

Johnson, Ronald C., 1987, Geologic history and hydrocarbon potential of Late Cretaceous-age, lowpermeability reservoirs, Piceance basin, westem Colorado, DOE/MC/20422-2337 (DE87006476), Distribution Category UC-132, p. 97 p.

Johnson, Ronald C., 1989, Detailed cross sections correlating Upper Cretaccous and Lower Tertiary rocks between the Uinta Basin of eastem Utah and western Colorado and the Piceance basin of western Colorado, U.S. Geological Survey Miscellaneous Investigations Series Map I-1974, p. 2 sheets.

Johnson, Vard H., 1956, Cross-section, coal deposits of the Book Cliffs, Central Utah to Westem Colorado: Peterson, J.A., ed., Intermountain Association of Petroleum Geologists seventh Annual Field Conference: Gcology and Economic Deposits of East Central Utah, p. 124.

Johnson, Vard H., 1976, Metamorphic pattems in western Cretaceous coals and their geoenvironmental implications: Brigham Young University Geology Studies, v. 22, Pan 3, p. 4558.

Juntgen, H., and Karweil, J., 1966, Gasbildung und gasspeicherung in steinkohlenflozen, Part I and II: Erdol and Kohle, Erdgas, Petrochemie, v. 19, p. 251-258, 339-344.

Juntgen, H., and Klein, J., 1975, Entstehung von erdgas guskohligen sedimenten: Erdol and Kohle, Erdgas, Petrochemie, Erganzungsband, v. 1, p. 52-69.

Keighin, C.W., and Fouch, T.D., 1981, Depositional environments and diagenesis of some nonmarine Upper Cretaceous reservoir rocks, Uinta basin, Utah, in Ethridge, F.G., and Flores, R.M., eds., Recent and Ancient Nonmarine Depositional Environments: Models for Exploration: Society of Economic Palcontologists and Mineralogists Special Publication No. 31, p. 109-125.

Keith, A.C., Hand, J.S., and Smith, A.D., 1991, Coalbed methane resource map, Castlegate A bed, Book Cliffs coal field, Utah: Utah Geological Survey, Report Number 176A. 
Keith, A.C., Hand,J.S., and Smith, A.D., 1991, Coalbed methane resource map, Castlegate B bed, Book Cliffs coal field, Utah: Utah Gcological Survey. Report Number 176B.

Kcith, A.C., Hand, J.S., and Smith, A.D., 1991, Coalbed methane resource map, Castlegate $C$ bed, Book Cliffs coal field, Utah: Utah Geological Survey, Report Number 176C.

Kcith, A.C., Hand, J.S., and Smith, A.D., 1991, Coalbed methane resource map, Castlegate Gilson bed, Book Cliffs coal field, Utah: Utah Geological Survey, Report Number 176D.

Knutson, C.F., and L. T. Hodges, 1981, Development of techniques for optimizing selection and completion of western tight gas sands, comparison of core, geophysical log, and outcrop information, phase III report, U.S. Department of Energy Report DOE/BC10005-3, 54 p., 14 figs, 7 plates.

Knutson, C.T., Hodges, L.T., and Righter, S.B., 1981, Permeability, petrography and small scale structural element analysis of Upper Cretaceous channel sandstone from the Rock Springs Uplift and Wind River Basin, Wyoming, in Proceedings of the 1981 SPE/DOE Symposium on Low Permeability Gas Reservoirs: Society of Petroleum Engineers and U.S. Department of Energy, SPE/DOE paper 9874 , p. $427-436$.

Koesoemadinata, R.P., 1970, Stratigraphy and petroleum occurrence, Green River Formation, Red Wash Field, Utah: Quarterly of the Colorado School of Mines, v. 65, no. 1, p. 1-77.

Law, B.E., Nuccio, V.F., and Barker, C.E., 1989, Kinky vitrinite reflectance profiles-evidence of paleopore nressures in low-permeability, gasbearing sequences in the Rocky Mountain foreland basins: American Association of Petroleum Geologists Bulletin, v. 73, no. 8, p. 999-1010.

Lucas, P.T., and J.M. Drexler, 1976, AltamontBluebell - a major naturally fractured stratigraphic trap: American Association of Petroleum Geologists Memoir 24, North American Oil and Gas Fields, p. 121-135.

Mackenzie, A.S., and Quigley, T.M., 1988, Principles of geochemical prospect appraisal: American Association of Petroleum Geologists Bulletin, v. 72 , p. $399-415$.

Meissner, F.F., 1984, Cretaceous and Lower Tertiary coals as source for gas accumulation in the Rocky Mountain area, in Woodward, Jane, Mcissner, F.F., and Clayton, J.L., eds., Hydrocarbon source rocks of the greater Rocky Mountain Region: Rocky Mountain Association of Geologists Symposium, Denver, CO., p. 401-432.
Miller, D.F., 1956, The Hill Creck area, Peterson, J.A., ed., Geology and Economic Deposits of East Central Utah, p. 199-201.

Multiwell Experiment Project Groups at Sandia National Laboratories and CER Corporation, 1990, Multiwell Experiment Final Report-IV. The Fluvial Interval of the Mesaverde Formation: Sandia report SAND89-2612/A.UC-132, Par A.

Myal,F.R., Price, E.H., Hill, R.E., Kukal, G.C., Abadie, P.A., and Riecken, C.C., 1989, Geologic and production characteristics of the tight Mesaverde Group: Piceance basin, Colorado: U.S. Department of Energy, Report Number DOE/MC/24120-2769 (DE90000415), $126 \mathrm{p}$.

Narr, Wayne, and Currie, J.B., 1982, Origin of fracture porosity-example from Altamont field, Utah: American Association of Petroleum Geologists Bulletin, v. 66, no. 9, p. 1231-1247.

Naylor, W.V., Jr., 1957, The Roosevelt, Duchesne, and County' fields, Uintah County, Utah: Intermountain Association of Petroleum Geologists Eigth annual Field Conference Guidebook to the Geology of the Uinta Basin, p. 188-190.

Nuccio, V.F., and Fouch, T.D., 1992, in press (1992), Theimal maturity of the Mesaverde Group, Uinta B 'sin, Utah, in Magoon, L.B., ed., The Petroleum System-Status of Research and Methods 1992: U.S. Geological Survey Bulletin 2007, p. 70-78.

Nuccio, V.F., and Johnson, R.C., 1986, Thermal maturity map of the Lowr, part of the Upper Cretaceous Mesaverde Group, Uinta Basin, Utah: U.S. Geological Survey Miscellaneous Field Studies Map MF-1842, one plate.

Nuccio, V.F., and Jol inson, R.C., 1988, Surface vitrinite reflectance map of the Uinta, Piceance, and Eagle basins area, Utah and Colorado: U.S. Geological Survey Miscellaneous Field Studies Map MF2008-B, 21 p., one plate.

Nuccio, V.F., and R.C. Johnson, 1989, Variations in vitrinite reflectance values for the Upper Cretaceous Mesaverde Formation, southeastern Piceance basin, northwestem Colorado-implications for burial history and potential hydrocarbon generation: U.S. Geological Survey Bulletin 1787-H, p. H1-H10, 1 plate.

Nuccio, V.F., Schmoker, J.W., and Fouch, T.D., 1991 , Thermal maturity, porosity, and facies relationships applied to gas generation and production in Tertiary and Cretaceous low-permeabilty sandstones, Uinta Basin, Utah [abs.]: American Association of Petroleum Geologists Bulletin, v. 75, no. 6, p. 1134-1135. 
Osmond, J.C., 1990, Gas in Casulegate Sandstone, Uinta basin, Utah and Douglas Creek Arch, Colorado [abs.]. American Association of Petroleum Geologists Bulletin, American Association of Petroleum, v. 74, nc. 8, p. 1340.

Osmond, J.C., 1990, Greater Natural Buttes Field, Uinta basin, Utah: an example of enhanced "tight" sands gas accumulation [abs.]: American Association of Petroleum Geologists Bulletin, v. 74 , no. 5, p. 735 .

Osmond, John C, 1957, Brennan Bottom Oil Field, Uintah County, Utah: Intermountain Association of Petroleum Geologists Eigth annual Field Conference Guidebook to the Geology of the Uinta Basin. p. 185-187.

Osmond, John C., 1985, Reservoir sandstone patterns, Green River Formation, Duck Creek Oil Ficld, Uintah County, Utah, Utah Geological Association Publication 12: Geology and Energy Resources, Uinta Basin of Utah, p. 187-192.

Owen, A.E., and George W. Whitney, 1956, San Arroyo-Bar X area, Grand County, Utah and Mesa County, Colorado, Peterson, J.A., ed.: Geology and Economic Deposits of East Central Utah, p. 195-198.

Picard, M.D., 1957. Green River and Lower Uinta Formations-Subsurface stratigraphic changes in central and eastem Uinta basin, Utah: Seal, O.G., ed.: Intermountain Association of Petroleum Geologists Eigth annual Field Conference Guidebook to the Geology of the Uinta Basin, p. 116-130.

Picard, M.D., and L.R. High Jr., 1970, Sedimentology of oil-impregnated, lacustrine and fluvial sandstone, P.R. Spring area, southeast Uinta basin, Utah: Utah Geological and Mineralogical Survey Special Studies 33, $32 \mathrm{p}$.

Pitman, J.K., Anders, D.E., Fouch, T.D., and Nichols, D.J., 1986, Hydrocarbon potential of nonmarine Upper Creta cous and Lower Tertiary rocks, eastem Uinta basin, Utah, in Spencer, C.W., and Mast, R.F., eds., Gcology of Tight Gas Reservoirs: American Association of Petroleum Geologists Studies in Geology No. 24, p. 235-252.

Pitman, J.K., Fouch, T.D., and Goldhaber, M.B., 1982, Depositional setting and diagenetic evolution of some Tertiary unconventional reservoir rocks, Uinta basin, Utah: American Association of Petroleum Geologists Bulletin, v. 66, no. 10, p. 1581-1596.

Pitman, J.K., Franczyk, K.J., and Anders, D.E., 1987. Marine and nonmarine gas-bearing rocks in Upper Cretaceous Blackhawk and Neslen Formations, eastern Uinta Basin, Utah-Sedimentology, diagenesis, and source rock potential: American Association of Petrolcum Geologists Bulletin, v. 71, no. 1, p. 76-94.

Pitman, J.K., Franczyk, K.J., and Anders, D.E., 1988, Diagenesis and burial history of nonmarine Upper Cretaceous rocks in the central Uinta basin, Utah: U.S. Geological Survey Bulletin 1787-D, 24 p.

Pitman, J.K., Goldhaber, M.B., and Fouch, T.D., 1986, Mineralogy and stable isotope geochemistry of carbonate and sulfate minerals in diagenetically altered Tertiary and Cretaceous sandstones, Uinta basin, Utah, in Mumpton, F.A., ed., Studies in Diagenesis: U.S. Geological Survey Bulletin 1578, p. 207-218.

Pitman, J.K., Spencer, C.W., and Pollastro, R.M., 1989, Petrography, mineralogy, and reservoir characteristics of the Upper Cretaccous Mesaverde Group in the east-central Piceance basin, Colorado: U.S. Geological Survey Bulletin 1787-G, 31 p.

Remy, R.R., 1989, Chapter 1-Deltaic and lacustrine facies of the Green River Formation, southern Uinta basin, Utah: International Geological Congress Field Trip Guidebook T119, Cretaccous Shelf Sandstones and Shelf Depositional Sequences, Western Interior Basin, Utah, Colorado and New Mexico, p. 1-12.

Rice, D.D., 1983, Relation of natural gas composition to thermal maturity and source rock type in San Juan basin, northwestern New Mexico and southwestem Colorado: American Association of Petroleum Geologists Bulletin, v. 67, p. 1199 1218.

Rice, D.D., and Claypool, G.E., 1981, Generation, accumulation, and resource potential of biogenic gas: American Association of Petrolcum Geologists Bulletin, v. 65, p. 1199-1218.

Ritzma, H.R., 1974, Cross-section southeast Asphalt Ridge, Uintah County, Utah: Utah Geological Association Publication 4, ed., Energy Resources of the Uinta Basin, p. 60.

Robbins, V. L., 1979, Interpretation of Anomalies on Homer Plots f D. S. T's: paper presented at the 7th Formation Evaluation Symposium of the Canadian Well Logging Society in Calgary, October 21, 22, 23 and 24, $19 \% 9$.

Rowley, P.D., Hansen W.R., Tweto, Ogden, and Carrara, P.E., 1985, Geologic Map of the Vernal $1 \times 2$ Quadrangle, Colorado, Utah, and Wyorning: U.S. Geological Survey Miscellancous Investigations Map I-526, scale 1·?50,000.

Ryder, R.T., Fouch, T.D., and Elison, J.H., 1976, Early Tertiary sedimentation in the western Uinta Basin. 
Utah: Geological Society of America Bulletin, v. 87 , no. 4, p. 496-512.

Sanborm, Albert F., 1977, Possible future petroleum of Uinta and Piceance basins and vicinity, northeast Utah and Northwest Colorado, in Veal, Harry K., ed., Rocky Mountain Association of Geologists Symposium: Exploration Frontiers of the Central and Southern Rockies, p. 151-166.

Schmoker, J. W., and Gautier, D. L., 1989, Compaction of basin sediments-modeling based on timetemperature history: Joumal of Geophysical Research, v. 94, no. B6, p. 7379-7386.

Schmoker, J. W., and Hester, T. C., 1990, Regional trends of sandstone porosity versus vitrinite reflectance-a preliminary framework, in Nuccio, V. F., and Barker, C. E., eds., Applications of thermal maturity studies to energy exploration: Rocky Mountain Section SEPM, Denver, p. 53-60.

Schocll, M, 1980. The hydrogen and carton isotopic composition of methane from natural gases of various origins: Geochimica et Cosmochimica, v. 44 , p. 649-661.

Schoell, M. 1983, Genetic characterization of natural gases: American Association of Petroleum Geologists Bulletin, v. 67, p. 2225-2238.

Schoell, M. 1988, Multiple origins of methane in the Earth: Chemical Geology, v. 71, p. 1-10.

Shanmugam, G., and Higgins, J.B., 1988, Porosity enhancement from cher dissolution beneath Neocomian unconformity-Ivishak Formation, North Slope, Alaska: American Association of Petrolcum Geologists Bulletin, v. 72, no. 5, p. 523535.

Spencer, C.W., and Keighin, C.W., eds., 1984, Geologic studies in support of the U.S. Department of Energy Multiwell Expcriment, Garficld County, Colorado: U.S. Geological Survey Open-File Report 84-757, $134 \mathrm{p}$.

Spencer, C.W., and Law, B.E., 1988, Unconventional resources-western tight gas reservoirs, in USGSMMS working paper-National assessment of undiscovered conventional oil and gas resources: U.S. Geological Survey Open-File Repor 88-373, p. $480-500$.

Spencer, C.W., and Wilson, R.J., 1988, Petroleum geology and principal exploration plays in the Uinta-Piceance-Eagle basins province, Utah and Colorado: U.S. Geological Survey Open-File Repon 88-450, 35 p.

Spencer, Charles W., 1987, Hydrocarbon generation as a mechanism for overpressuring in Rocky Mountain region, American Association of
Petrolcum Geologists Bulletin, v. 71, n. 4, p. 368388, 17 Figs.

Spieker, E. M., 1946, Late Mesozoic and early Cenozoic history of central Utah: U.S. Gcological Survey Prriessional Paper 205-D, p. 117-161.

Stone, D.S., 1977, Tectonic history of the Uncomphagre uplith, in Veal, H.K., ed., Exploration Frontiers of the Central and Southem Rockics: Rocky Mountain Association of Geologists, p. 23-30.

Surdam, R.C., Dunn, T.L., MacGowen, D.B., and Heasler, H.P., 1989, Conceptual models for the prediction of porosity evolution with an example from the Frontier Sandstone, Bighorn basin, Wyoming, in Coalson, E.B., ed., Petrogenesis and petrophysics of selected sandstone reservoirs of the Rocky Mountain region: Rocky Mountain Association of Geologists, Denver, p. 7-28.

Sweeney, J.J., Bumham, A.K., and Braun, R.L., 1987, A model of hydrocarbon generation from type I kerogen-application to Uinta basin: American Association of Petroleum Geologists Bullctin, v.71, p. 967-985.

Szantay, Adam, Frank G. Ethridge, and Thomas D. Fouch, 1989, Palcomorphology of lower and middle Eocene Green River channel-form sandstones, Uinta Basin, Utah, USA; 1 page abstract for poster in Program for International Fluvial Conf, Spain, 1989.

Tissot, B.P., and Welte, D.H., 1984, Petroleum formation and occurrence: Springer-Verlag, New York, $699 \mathrm{p}$.

Tissot, B.P., Deroo, G., and Hood, A., 1978, Geochemical study of the Uinta basin-formation of petroleum from the Green River Formation: Geochimica et Cosmochimica Acta, v. 42, p. 14691485.

Tissot, B.P., Durand, B., Espitalic, J., and Combaz, A., 1974, Influence of nature and diagenesis of organic matter in formation of petroleum: American Association of Petrolcum Geologists Bulletin, v. 58, p. 499-506.

Tissot, B.P., Pelet, R., and Ungerer, Ph., 1987, Thermal history of sedimentary basins, maturation indices, and kinetics of oil and gas generation: American Association of Petrolcum Geologists Bulletin, v. 71, p. 1445-1466.

Utah Geological and Mineral Survey, 1967, Reflection seismograph survey, Asphalt Ridge area, Uintah County, Utah, by Petty Geophysical Engineering Company, Incorporated: Utah Geological and Mineral Survey Unnumbered Open-file repor, November 1967. 
Walton, P.T., 1964, Late Cretaceous and Early Paleocene conglomerates along the margin of the Uinta Basini, in Sabatka, E.F., cd.: Guidebook to the Geology and Mineral Resources of the Uinta Basin, p. 139-144.

Walton, Paul T., 1957, Cretaceous stratigraphy of the Uinta Basin: Intermountain Association of Petroleum Geologists eighth Annuai Field Conference: Uinta Basin, p. 97-101.

Waples, D.W., 1980, Time and temperature in petroleum formation-application of Lopatin's method to petroleum exploration: American Association of Petroleum Geologists Bulletin, v. 64, p. 916-926.

Waples, D.W., 1985, Geochemistry in petroleum exploration: Boston, International Human Resources Development Corporation, 232 p.

Wendlandt, R.F., and Bhuyan, Kamal, 1990, Estimation of mineralogy and lithology from geochemical log measurements: American Association of Petroleum Geologists Bulletin, v. 74, no. 6, p. 837-856.

Wesley, J. B., 1990, Finite difference modeling of present day overpressures maintained by hydrocarbon generation, and regional fluid flow in the Green River Formation, Uinta basin, Utah: unpublished M.S. Thesis T-3826, Colorado School of Mines, $139 \mathrm{p}$.

Wesley, J.B., Wandrey, C.J., and Fouch, T.D., in press (1991), Principal drill stem test database (UBDST) and documentation-analysis of Uinta Basin, Utah gas-bearing Cretaceous and Tertiary strata: U. S. Department of Energy report, 19 ms pages, 4 figs, computer disks.

Willet, S.D., and D.S. Chapman, temperatures, fluid flow and thermal history of the Uinta basin, p. 533551, 8 figs.,

Willet, Sean D., and David S. Chapman, 1987, Analysis of temperatures and thermal processes in the Uinta basin, in Beaumont, C., and A.J. Tankard, ed., Sedimentary Basins and Basin-Forming Environments: Canadian Society of Petrololeum Gcologists Memoir 12, p. $447-461,17$ figs., 1 table. 

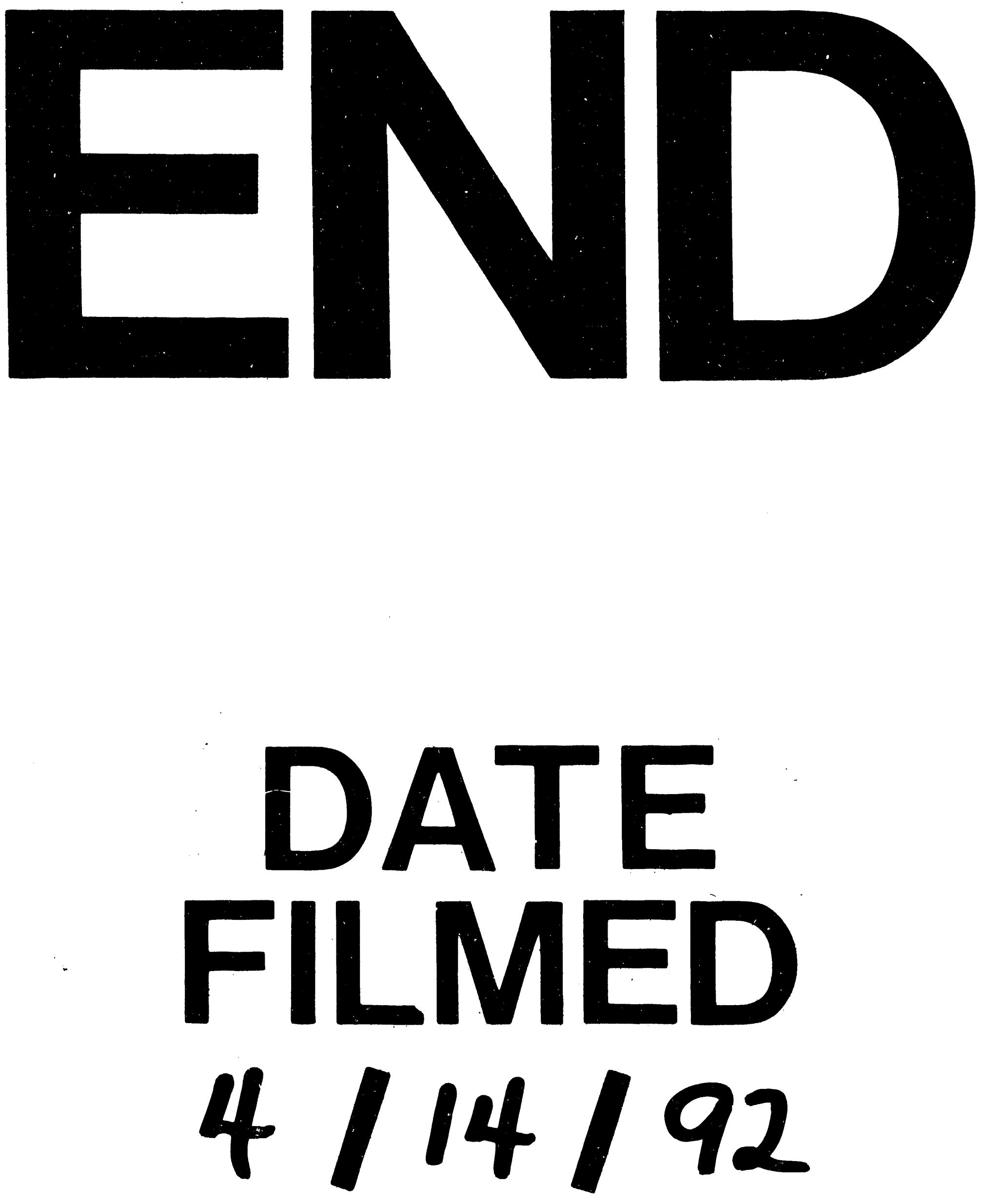

I 
